\title{
AMBIENTE COMPETITIVO E COMPORTAMENTO DO MERCADO FARMACÊUTICO VETERINÁRIO NO BRASIL
}

\author{
SYLVIA LOLOMA HACKER
}

Médica Veterinária

Orientador: Prof. Dr. MARCOS SAWAYA JANK

Dissertação apresentada à Escola Superior de Agricultura "Luiz de Queiroz", da Universidade de São Paulo, para obtenção do título de Mestre em Ciências. Área de Concentraçåa: Economia Aplicada.

PIRACICABA

Estado de São Paulo - Brasil

Maio - 2000 
Dados Internacionais de Catalogação na Publicação (CIP) DIVISÃo DE BIBLIOTECA E DOCUMENTAÇĀO - Campus "Luiz de Queiroz"/USP

Hacker, Sylvia Loloma

Ambiente competitivo e comportamento do mercado farmacêutico veterinário no Brasil / Sylvia Loloma Hacker. - - Piracicaba, 2000.

$115 \mathrm{p}$.

Dissertação (mestrado) -. Escola Superior de Agricultura Luiz de Queiroz, 2000. Bibliografia.

1. Competição industrial 2. Indústria farmacêutica 3. Medicamento veterinário 4. Mercado I. Titulo

CDD 338.476360895

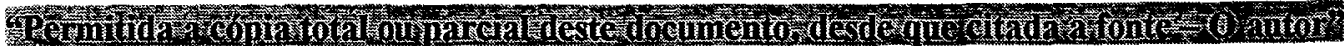


Dedico esta tese a todos que, de alguma forma, ajudaram-me, ouvindo com paciência minhas dúvidas, contribuindo com idéias e dando-me incentivos. Em especial, dedico aos meus pais que, sem dúvida, foram as pessoas que mais me orientaram na vida, sempre presentes, maravilhosos, exemplos de que a dedicação supera qualquer obstáculo. Dedico ao meu querido irmão Conrad e sua esposa Carla, à minha amada irmã gêmea Sibylle e seu marido Marcos, que sempre se prontificou a contribuir com leituras, e à minha querida irmã caçula Undine, cuja perseverança é admirável. Com especial carinho, dedico ao meu marido, que sempre me apoiou em todas as minhas decisões e cujo amor é um incentivo para seguir em frente. Dedico também esta tese a todos os animais, razão pela qual escolhi minha profissão e vida. 


\section{AGRADECIMENTOS}

Gostaria de agradecer a algumas pessoas que contribuíram para a produção desta tese, sem ordem de preferência.

Ao meu orientador, Prof. Marcos S. Jank, que acreditou em mim e na minha tese e que sempre me incentivou e respeitou minhas idéias, os meus mais sinceros agradecimentos.

À banca de qualificação de tese, composta pelo Prof. Marcos Neves e pelo Prof. Pedro Marques, pelas contribuições elucidativas fornecidas.

À "equipe de apoio", se posso assim chamar, da Escola Superior de Agricultura “Luiz de Queiroz", Maielli, Helena, Cristiane, Sr. Pedro, Márcia, Waldeci, Luciane, por sempre atenderem às minhas dúvidas e necessidades com simpatia, profissionalismo e prontidão.

Aos professores do Departamento de Economia e Sociologia da Escola Superior de Agricultura "Luiz de Queiroz", que me proporcionaram a oportunidade de aprendizado. Em especial, gostaria de agradecer ao Prof. Caixeta e à Profa. Zilda, por terem acreditado em mim e no meu trabalho. Ao Prof. Bacha, por se dispor a ler e comentar o meu trabalho, tanto no seminário como na participação da banca de defesa da tese, sendo suas contribuições de grande valia.

Agradeço também à Faculdade de Economia, Administração e Contabilidade da USP, campus Ribeirão Preto. Ao Prof. Sigismundo Bialoskorsky, por ter contribuído com sugestões na apresentação do seminário e, reforçando o agradecimento, ao Prof. Marcos Neves por se dispor a participar na banca de defesa de tese, cujas contribuições na qualificação foram de grande valia.

Às minhas amigas, sempre presentes, onde quer que eu esteja, muito obrigada. Em especial, obrigada à minha amiga Maria Claudia, que mais de uma vez leu meu trabalho, procurando por erros que eu já não conseguia enxergar.

Gostaria de dedicar um especial agradecimento a um profissional da área farmacêutica veterinária que muito me incentivou, Roberto Waack, uma pessoa admirável, tanto profissionalmente como pessoalmente. Os meus mais sinceros 
agradecimentos a todos da equipe Boehringer Ingelheim, que sempre foram profissionais, amigos e companheiros e que muito me ensinaram. Também agradeço a todos os profissionais do setor farmacêutico veterinário que me atenderam nas entrevistas, sempre simpáticos e disponíveis. Sem me esquecer do SINDAN, representado pela pessoa do Sr. Milson, cuja atenção foi essencial para o desenvolvimento do trabalho.

À minha orientadora de iniciação científica Silvana Górniak, que me ensinou a apreciar a área farmacológica. Ao Departamento de Farmacologia e Toxicologia da Faculdade de Medicina Veterinária agradeço pelo conhecimento que adquiri nos dois anos em que ali trabalhei e, por fim, sinceros agradecimentos à minha escola de graduação. 


\section{SUMÁRIO}

Página

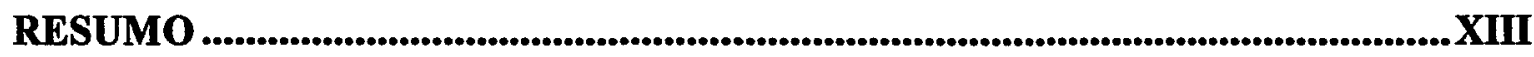

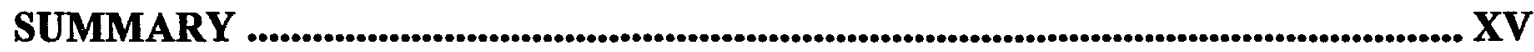

1. INTRODUÇÃO ............................................................................................. 17

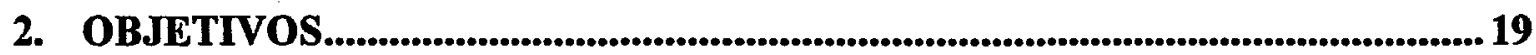

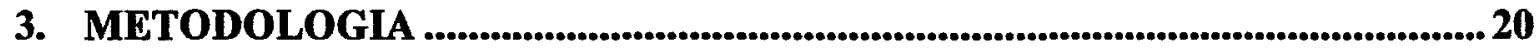

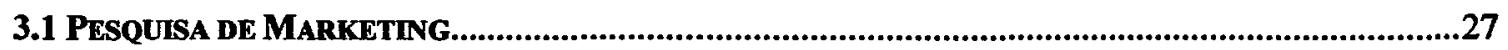

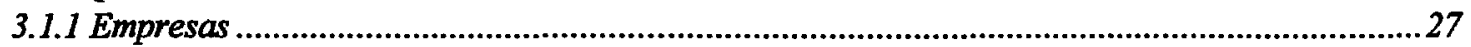

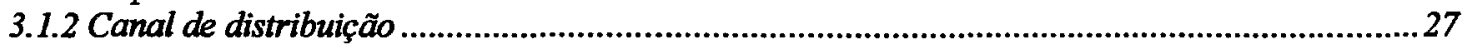

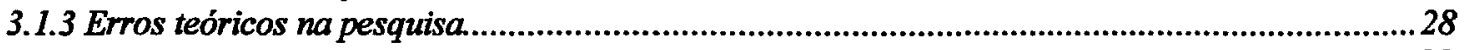

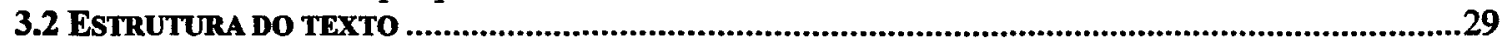

4. ENQUADRAMENTO TEÓRICO.......................................................................... 30

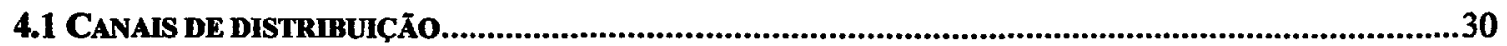

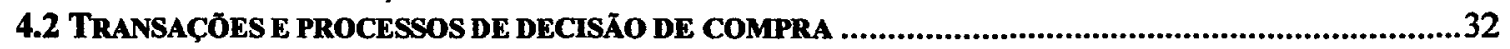

5. RESULTADOS DA PESQUISA DE CAMPO: DESCRIÇÃO DO MERCADO,

CANAIS E TRANSAÇÔES....................................................................................34

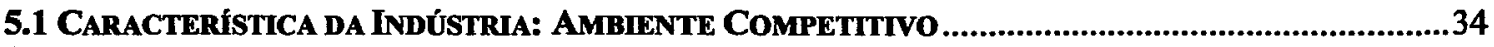

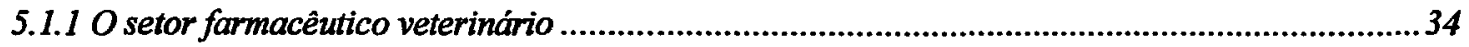

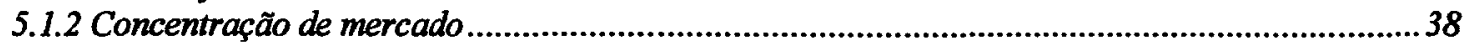

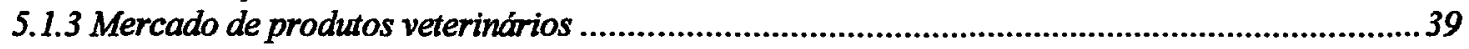

5.1.4 Evolução do setor no Brasil............................................................................................43

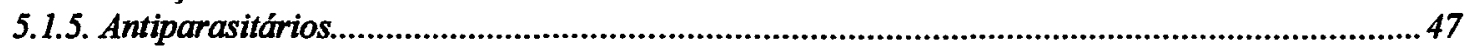

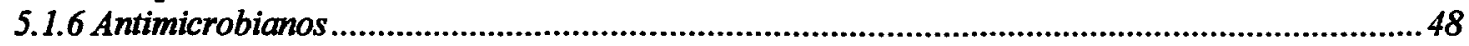

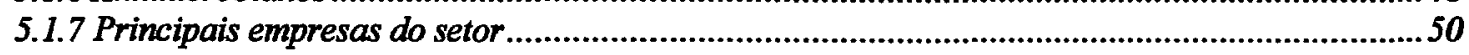

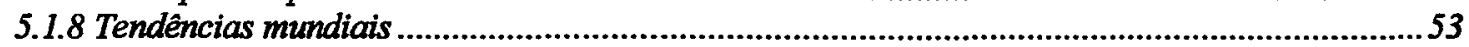

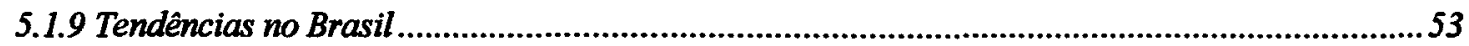

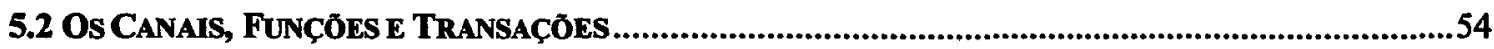

6. RESULTADOS DA PESQUISA DE CAMPO SOBRE PERCEPÇÂO................. 62

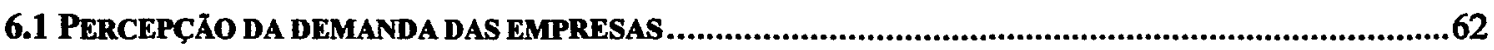

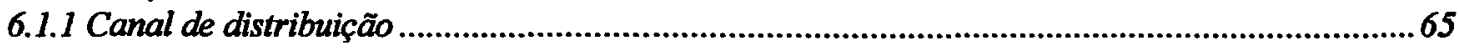

6.1.2 Formas de distribuição nas diferentes regiōes...............................................................68

6.1.3 Vendas por categoria animal nas diferentes regiöes.............................................................. 71

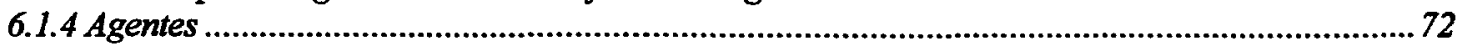

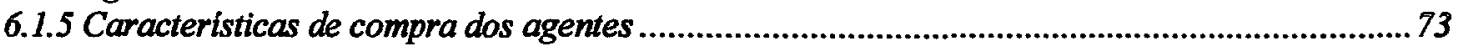

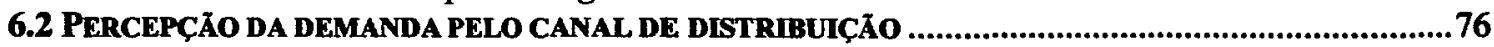

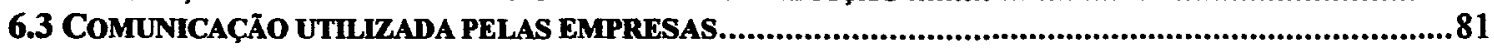

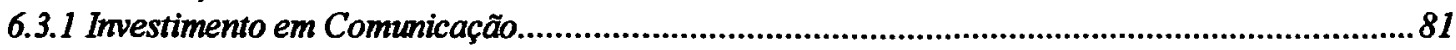

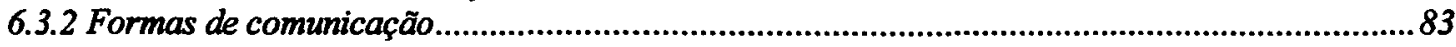

6.3.3 Comunicação eficaz sob a perspectiva dos canais de distribuição ........................................87 


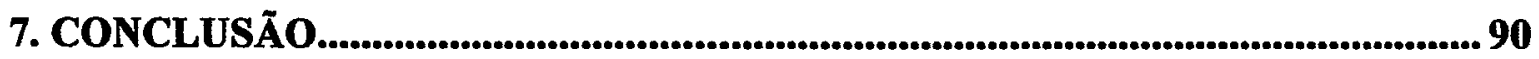

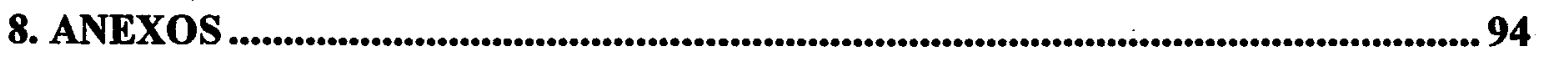

9. REFERÊNCIAS BIBLIOGRAFICAS......................................................... 97

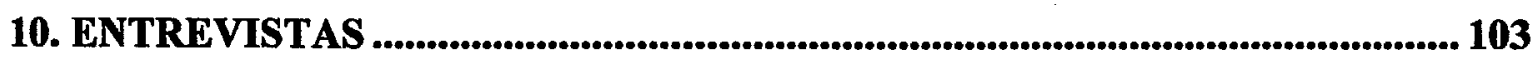

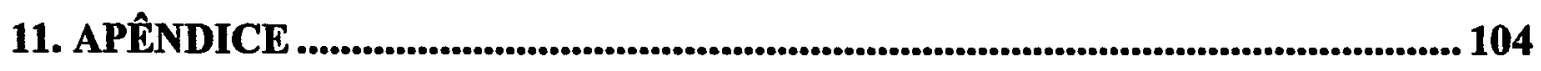




\section{LISTA DE FIGURAS}

Página

Figura 1- Procedimentos de coletas de dados .................................................................22

Figura 2 - Setor Químico ............................................................................................... 35

Figura 3 - Rota de obtenção de produtos biológicos ............................................................ 37

Figura 5 - Distribuição das vendas no Brasil para cada espécie animal ........................... 45

Figura 6 - Cadeia Industrial de färmacos veterinários..................................................5 56

Figura 7 - Venda direta de antiparasitários para bovinocultura de leite ............................. 85

Figura 8 - Venda direta de antibióticos para bovinocultura de leite................................. 85

Figura 9 - Venda direta de antiparasitários para Eqüinocultura.....................................88

Figura 10 - Venda direta de antibióticos para Eqüinocultura .......................................8 


\section{LISTA DE QUADROS}

Página

Quadro 1- Etapas do processo de pesquisa de marketing .................................................21

Quadro 2 - Cadeia agroindustrial do setor farmacêutico veterinário................................55

Quadro 4 - Resultados dos questionários.....................................................................62 


\section{LISTA DE TABELAS}

Página

Tabela 1 - Classificação dos produtos químicos (em função da escala de produção, produtos obtidos e valor agregado). 36

Tabela 2 - Despesas com P\&D (de algumas empresas por linha de produto principal)... 38

Tabela 3 - Principais fusões e aquisições no setor farmacêutico veterinário 39

Tabela 4 - Crescimento do mercado mundial entre 1996 e 1997 40

Tabela 5 - Participação percentual nas vendas por espécie animal (no Brasil e no mundo) 41

Tabela 6 - Vendas por espécie. 41

Tabela 7 - Participação dos produtos nas vendas mundiais e brasileiras 42

Tabela 8 - Vendas de produtos veterinários no Brasil de 1989 a 1997 44

Tabela 9 - Principais países nas vendas de produtos veterinários. 46

Tabela 10 - Ranking das dez maiores empresas mundiais do setor farmacêutico veterinário em 1994 e 1998 50

Tabela 11 - As maiores empresas de produtos veterinários no Brasil, 1994 e $1998 . . . . . .52$

Tabela 12 - Formas de distribuição predominantes utilizadas pelas empresas por região 57

Tabela 13 - Faixa de comissão concedida aos vendedores autônomos 57

Tabela 14 - Padrão de concessão de descontos por linha de produto. 57

Tabela 15 - Padrão de concessão de descontos concedidos por canal de distribuição .... 57

Tabela 16 - Comparação das variáveis de marketing entre produtos genéricos e especialidades.

Tabela 17 - Percentagem de empresas entrevistadas que disseram trabalhar com as diferentes formas de distribuição 66

Tabela 18 - Capacidade de agregação de valor das empresas distribuidoras de insumos veterinários 67 
Tabela 19 - Freqüência com que as formas de distribuição foram citadas como importantes pelas empresas nas diversas regiōes para antiparasitários

Tabela 20 - Frequiência com que as formas de distribuição foram citadas como importantes pelas empresas nas diversas regiões para antibióticos.

Tabela 21 - Comparação entre vendedores autônomos e vendedores próprios 70

Tabela 22 - Distribuição da freqüência da importância das regiões como representativas nas vendas de antiparasitários pelas empresas

Tabela 23 - Distribuição da freqüência da importância das regiões como representativas nas vendas de antibióticos pelas empresas.

Tabela 24 - Distribuição da freqüência com que os agentes foram citados como importantes "influenciadores da demanda" na bovinocultura de leite pelas empresas .... 72

Tabela 25 - Distribuição da freqüência com que os agentes foram citados pelas empresas como os mais importantes "influenciadores da demanda" na eqüinocultura 73

Tabela 26 - Distribuição da freqüência dos atributos considerados importantes, em ordem de preferência, na decisão de compra na bovinocultura de leite, sob a perspectiva das empresas.

Tabela 27 - Distribuição da freqüência com que os atributos foram citados como importantes, em ordem de preferência, na decisão de compra na eqüinocultura, sob a perspectiva das empresas

Tabela 28 -Distribuição da freqüência com que as diferentes faixas etárias dos clientes foram citadas como importantes em cada região, sob a perspectiva do canal de distribuição.

Tabela 29 - Distribuição da frequiência com que as principais fontes de renda foram citadas como importantes em cada região, sob a perspectiva do canal de distribuição ... 76

Tabela 30 - Distribuição da frequiência, em porcentagem, com que os agentes foram citados como importantes, sob a perspectiva do canal de distribuição

Tabela 31 - Distribuição da freqüência, em porcentagem, com que o veterinário é chamado à propriedade rural nas diferentes regiões, sob a perspectiva do canal de distribuição

Tabela 32 - Distribuição da freqüência de finalidade de compra nas diferentes regiões, sob a perspectiva do canal de distribuição 
Tabela 33 - Distribuição da frequêência dos atributos considerados importantes pelo consumidor na decisão de compra na pecuária leiteira, sob a visão do canal de distribuição.

Tabela 34 - Distribuição da freqüêencia com que os atributos foram citados como importantes na decisão de compra na eqüinocultura, sob a perspectiva do canal de distribuição.

Tabela 35 - Distribuição da freqüência das empresas versus Investimento em Marketing

Tabela 36 - Distribuição da freqüência das diferentes formas de comunicação que foram citadas como adotadas em 1998 pelas empresas. 83

Tabela 37 - Medida de tendência central* das formas de merchandising por categoria de produto utilizados pelas empresas

Tabela 38 - Distribuição da frequiência com que as formas de comunicação foram consideradas mais eficazes para pecuária de leite de acordo com o canal de distribuição

Tabela 39 - Distribuição da freqüência das formas de comunicação consideradas mais eficazes junto aos pecuaristas de leite de acordo com o canal de distribuição .88

Tabela 40 - Distribuição da frequiência das formas de divulgação e promoção consideradas como as mais importantes na Eqüinocultura pelo canal de distribuição .... 88

Tabela 41 - Distribuição da frequêencia das formas de propaganda consideradas como as mais importantes na Eqüinocultura pelo canal de distribuição 


\title{
AMBIENTE COMPETITIVO E COMPORTAMENTO DO MERCADO FARMACÊUTICO VETERINÁRIO NO BRASIL
}

\author{
Autora: SYLVIA LOLOMA HACKER \\ Orientador: Prof. Dr. MARCOS SAWAYA JANK
}

\section{RESUMO}

Essa dissertação tem por objetivo estudar o ambiente competitivo do setor farmacêutico veterinário no Brasil, identificar os diferentes canais de distribuição utilizados pelas empresas e comparar a percepção que a indústria farmacêutica veterinária e os canais de distribuição têm em relação a produtores rurais. Para caracterizar o ambiente competitivo das indústrias farmacêuticas, utilizaram-se dados secundários disponíveis. $\mathrm{Na}$ identificação dos diferentes canais de distribuição utilizados pelas empresas e na pesquisa qualitativa da percepção da demanda de medicamentos veterinários, foram aplicados dois questionários desenvolvidos pela autora a partir da metodologia proposta por Aaker et al. (1997).

O setor farmacêutico veterinário representa, mundialmente, um mercado que movimenta em torno de doze bilhões de dólares ao ano. O Brasil é o terceiro maior mercado de consumo de medicamentos veterinários, cujo volume de negócios encontrase em torno de 800 milhões de dólares.

Nos últimos anos, a indústria farmacêutica veterinária tem sido marcado por fusões entre empresas multinacionais, levando a uma reestruturação do ambiente competitivo. Essa tendência de concentração justifica-se por ser este um dos setores de produção nos 
quais a tecnologia exerce papel importante no desenvolvimento econômico das empresas, requerendo investimentos vultosos em pesquisa e desenvolvimento.

Tendências de mudanças dos principais produtos consumidos, assim como declínio e crescimento de grupos consumidores evidenciaram-se nesta última década. Destaca-se nesse contexto o aumento de consumo de produtos para os animais de companhia, representados por cães, gatos e eqüinos. Os principais medicamentos comercializados mundialmente são os antiparasitários e as vacinas, que, juntamente com as especialidades, têm as maiores expectativas de crescimento na demanda. Acredita-se também que haverá um cruzamento entre a linha farmacológica humana e o desenvolvimento de medicamentos para uso animal.

Enquanto nos países desenvolvidos, o aumento da lucratividade está ligado ao lançamento de novos produtos, no Brasil, diferentemente, ainda há a oportunidade de crescimento quantitativo. Os antiparasitários são o principal produto de venda da indústria veterinária nacional, sendo o balconista do canal de distribuição o principal "agente influenciador" da compra. Por isso, o direcionamento da atividade de "marketing" é para o canal de distribuição e, em segmentos com maior exigência por qualidade, existe a tendência de o apoio técnico ser integrante do canal de distribuição.

O mercado de antibióticos, por outro lado, representa $14 \%$ do volume total de vendas de medicamentos veterinários no Brasil e $27 \%$ no mundo. Nele, há também forte potencial qualitativo com a introdução de novas moléculas de maior eficácia e facilidade de aplicação.

As empresas não concentram suas atividades de comercialização utilizando apenas um canal de distribuição. Na grande maioria, utilizam todos os canais. Porém há uma tendência dos distribuidores exclusivos estarem mais presentes na eqüinocultura, por permitir agregação de valor ao produto. Na pecuária de leite, por sua vez, não ficou evidente uma rota de comercialização predominante, constatando-se a presença de diferentes segmentos de consumo. Os canais são considerados, por muitos, como barreiras de entrada e não um composto mercadológico que oferece vantagens competitivas. 


\title{
COMPETITIVE MARKET AND THE BEHAVIOUR OF VETERINARY PHARMACEUTICAL MARKET IN BRAZIL
}

\author{
Author: SYLVIA LOLOMA HACKER \\ Adviser: Prof. Dr. MARCOS SAWAYA JANK
}

\section{SUMMARY}

The Animal Health Sector represents in the world markets sales of twelve billion dollars per year. Brazil, the third biggest market consume around 800 million dollars and therefore regarded as a strategic country to potential growth.

This sector in the last few years has been characterized by mergers and acquisitions causing a reorganization in the national competitive ambient as well as the worldwide competition. Considering this new context, the national and international firms have been forced to specialized themselves, turning to marketing strategies and focusing, basically, the regional segments markets.

Were evident in this decade trends like changes in the most consume products and decline and grow of some consumer groups, specially the increase consume for pets products, represented of dogs, cats and horses. On the other hand, the poultry and swine market in the future will be forced to adapt to changes in the consumer market.

Analyzing the consume market in Brazil, parasiticides are the main animal health products in sales. It's use is essentially without technical support and being the balcony 
salesperson the main buyer influenciador. The marketing focuses the wholesalers, although for the specialized segments require integrated technical support within the sales. The parasiticides consuming tends to be stable in time, although in few years with the specialization of the producers the quality consumes will increase.

The antibiotics market represents $14 \%$ of the market in Brazil and $27 \%$ worldwide. Qualitative grow perspective is also possible with more efficient and easier handle products.

The communication used is a mix between channel marketing and consumer marketing and focusing the relationship between the wholesalers and the industry it comes clear communications problems. The market channels are considered for few entrance barriers for the market instead of a key of advantage to reach the consumer.

To identify the competitive Brazilian Animal Health Sector and the behavior of parasiticides and antibiotics markets, surveys were made with the major veterinary firms and questionnaires were sent to the most representative wholesalers of this sector. Exploratory research was used, seeking insights about the general nature of the market. 


\section{INTRODUÇÃO}

A indústria farmacêutica veterinária corresponde a um setor que está presente em todos os segmentos que envolvem produção ou criação de animais. São tanto agentes fornecedores de insumos para a agropecuária como também consumidores de matéria prima para produção de medicamentos, movimentando, mundialmente, cerca de 12 bilhões de dólares por ano.

No Brasil há carência de trabalhos publicados que analisem o mercado farmacêutico veterinário sob o aspecto competitivo de demanda. Essa é a razão deste trabalho que se propõe a caracterizar o ambiente competitivo do setor, que movimentou aproximadamente 800 milhões de dólares em 1999 no Brasil. Tal cifra corresponde a 9\% do faturamento da indústria farmacêutica.

É também proposta deste trabalho identificar os diferentes canais de distribuição utilizados pelas empresas, sua importância na distribuição, na comunicação e no processo de decisão de compra. Por último, a partir de entrevistas de campo, buscou-se comparar a percepção que a industria farmacêutica veterinária e os canais de distribuição têm em relação aos produtores rurais .

Para caracterizar o mercado consumidor focou-se na demanda de antibióticos e antiparasitários, que juntos representam $45 \%$ do montante comercializado no Brasil. Escolheu-se o rebanho bovino de leite que, somado à pecuária de corte, é responsável por $30 \%$ do volume de vendas de medicamentos veterinários no mundo e $67 \%$ do volume no Brasil. O segmento de eqüinos também foi escolhido para análise já que, apesar de representar apenas 3,8\% do volume de negócios no Brasil, vem crescendo cerca de 8 a $10 \%$ a.a. em volume de negócios em âmbito mundial (Sauer, 1999). 
Acredita-se que a determinação da percepção da demanda e a caracterização do mercado consumidor de produtos veterinários contribuirá para o entendimento do setor, aumentando a qualidade dos dados disponíveis aos profissionais da área em seu planejamento estratégico de marketing. 


\section{OBJETIVOS}

O objetivo do presente trabalho é, numa primeira etapa, caracterizar o ambiente competitivo das indústrias farmacêuticas utilizando como referencial teórico a análise do ambiente competitivo proposta por Aaker et. al. (1997). Numa segunda etapa, objetivouse identificar os diferentes canais de distribuição utilizados pelas empresas, sua importância na distribuição, na comunicação e no processo de decisão de compra, partindo do conceito de vantagem competitiva proposto por Porter (1992). Por último, buscou-se comparar a percepção que a indústria farmacêutica veterinária e os canais de distribuição têm em relação a produtores rurais, a partir de entrevistas de campo. 


\section{METODOLOGIA}

Para caracterizar o ambiente competitivo das indústrias farmacêuticas, utilizaram-se dados secundários disponiveis. $\mathrm{Na}$ identificação dos diferentes canais de distribuição utilizados pelas empresas e na pesquisa qualitativa da percepção da demanda de medicamentos veterinários foram aplicados dois questionários desenvolvidos pela autora a partir da metodologia proposta por Aaker et al. (1997). Responderam aos questionários os principais canais distribuidores, indicados pelo SINDAN - Sindicato das Indústrias Farmacêuticas Veterinárias, via correio, e as principais indústrias, também segundo o SINDAN, através de entrevistas.

Segundo Mattar (1997, p.54):

"Pesquisa de marketing é a investigação sistemática, controlada, empírica e crítica de dados com o objetivo de descobrir e/ou descrever fatos ou de verificar a existência de relações presumidas entre fatos referentes ao marketing de bens, serviços e idéias, e ao marketing como área de conhecimento da administração."

A pesquisa partiu do pressuposto de que o consumidor, no ato da compra, confere a alguns atributos ponderação maior na sua decisão na compra. As empresas e os canais distribuidores têm percepções próprias dessa ponderação, que podem ser medidas através da pesquisa de marketing. Esta dissertação busca comparar as duas percepções de um mesmo elemento: fatores decisórios de compra de antiparasitários e de antibióticos.

Introduzindo um rápido conceito de marketing lançamos mão de uma das inúmeras definições: 
"Marketing é o processo de planejar e executar a concepção dos produtos, a determinação do preço, a promoção e a distribuição das idéias, bens e serviços, criando trocas que satisfaçam objetivos individuais e das organizações. $O$ conceito de Marketing requer que o objetivo da empresa seja muito mais a satisfação do cliente do que a maximização dos lucros. A essência do marketing é conhecer as atitudes dos clientes/consumidores em relação à empresa, seus produtos e produtos concorrentes (Aaker et al, 1997, p. 01)".

O processo de pesquisa de marketing compreende quatro diferentes etapas: reconhecimento do problema, planejamento, execução e comunicação dos resultados (Quadro 1).

Quadro 1- Etapas do processo de pesquisa de marketing
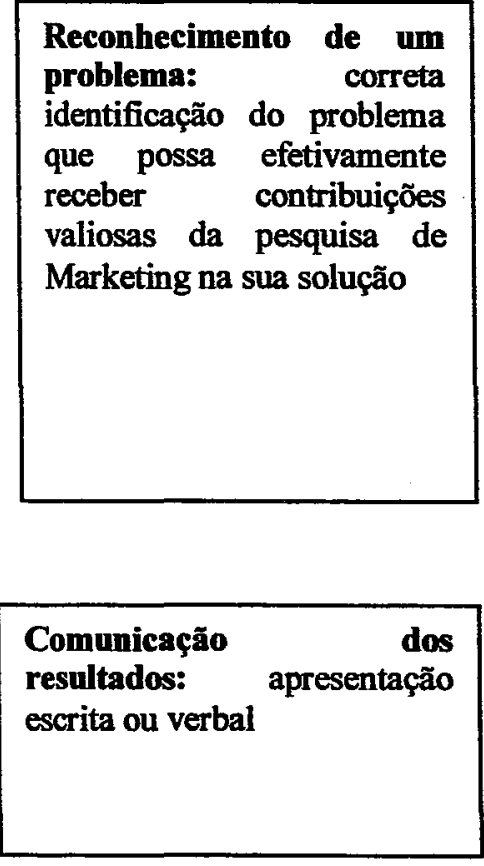

Fonte: Aaker et al., 1997
Planejamento: definição dos objetivos da pesquisa e toda sua operacionalização, estabelecimento das questões de pesquisa e (ou) formulação de hipóteses, estabelecimento das necessidades de dados e definição das variáveis de pesquisa e seus indicadores, planejamento da organização, cronograma e orçamento

Execução: preparação do campo (pré-teste), coleta de dados, conferência, correção processamento, análise $e$ interpretação 
A pesquisa de marketing pode ser feita através de vários procedimentos de coleta e de análise de dados (Figura 1). De acordo com Mattar (1991) e Aaker et al. (1997), pode-se classificar a pesquisa em exploratória ou conclusiva (descritiva ou causal).

Figura 1- Procedimentos de coletas de dados

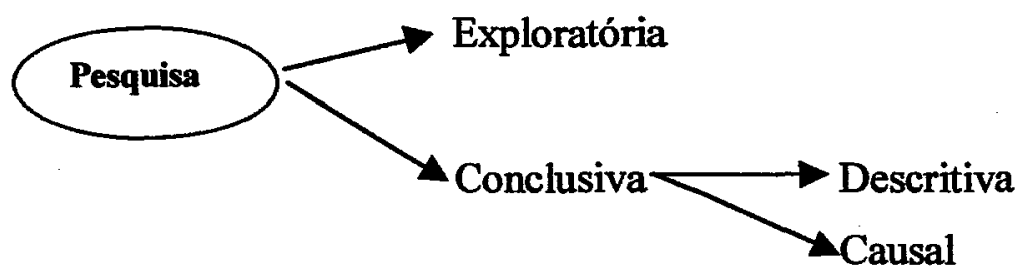

Fonte: Mattar (1997) e Aaker et al. (1997)

A pesquisa exploratória visa prover o pesquisador de um maior conhecimento sobre o tema ou problema. Este tipo de levantamento é útil quando se tem pouca noção sobre a questão e não há um conhecimento específico para se formular uma hipótese. As hipóteses, nesse caso, são vagas e mal definidas, podendo às vezes nem existir.

A pesquisa conclusiva pode ser descritiva ou causal. Esta última é utilizada quando as empresas desejam descobrir relações de causa e efeito entre as variáveis de decisão de marketing, que têm controle, e as variáveis de resultado, que não têm controle. A pesquisa conclusiva descritiva caracteriza-se por possuir objetivos bem definidos, utilizar procedimentos formais, ser bem estruturada e ter em vista solucionar problemas ou avaliar alternativas de curso de ação. É utilizada quando:

- Procura-se descrever características de grupos;

- Quer-se estimar a proporção de elementos numa população especifica que tenham determinadas características ou comportamento;

- Quer-se descobrir a existência de relação entre as variáveis. 
Ainda segundo Mattar (1997) e Aaker et al. (1997), há dois tipos básicos de pesquisa descritiva: levantamento de campo e estudos de caso. Com o primeiro, procuram-se obter dados representativos da população de interesse. Esse tipo de pesquisa apresenta grande amplitude e pouca profundidade. $O$ estudo de caso, por sua vez, apresenta média amplitude e média profundidade e, geralmente, é utilizado quando há interesse em conhecer o inter-relacionamento entre as variáveis que ocasionam um fenômeno.

$O$ projeto de pesquisa pode ser ocasional, quando elementos são medidos uma única vez no tempo e visa atender um objetivo específico, ou evolutivo quando se faz coleta e análise periódica das mesmas variáveis de forma a permitir um acompanhamento evolutivo no tempo.

Os dados úteis para o marketing são classificados em dois grupos: dados primários e secundários. Os primários são aqueles que nunca foram coletados e as fontes básicas para obtê-los são a pesquisa com pessoas diretamente relacionadas com o assunto e/ou entrevistas com pessoas que tenham a informação. Os dados secundários são os que já foram coletados, tabulados e ordenados. As fontes básicas são empresas, publicações, governo e instituições de serviço padronizado de marketing.

Para se obterem dados primários há dois meios: comunicação, utilizando-se questionário verbal ou escrito, e observação, em que se faz registro de comportamento. Quanto ao meio de comunicação, existem várias procedimentos e técnicas de conduzi-la:

- Estruturado não disfarçado: utilizado em pesquisas conclusivas, principalmente levantamentos amostrais e estudos de campo. O questionário aplicado é padrão a todos os entrevistados, na mesma ordem e com as mesmas opções de resposta. Requer o cuidado, por parte de seu desenvolvimento, para que não haja possíveis alternativas de resposta. Uma parte importante deste questionário é o pré-teste. A vantagem de seu uso é a simplicidade de sua aplicação, tabulação de dados e interpretação. As desvantagens são a dependência da boa vontade e da sinceridade do respondente, além da possível influência que a coleta pode exercer sobre as respostas. 
- Não estruturado não disfarçado: os propósitos do estudo são claros, mas não há uma estruturação predefinida das perguntas e das respostas. As respostas são abertas e a pessoa questionada tem liberdade de expressar suas percepções, crenças, valores, opiniões, experiência, atitude, estilo de vida, comportamento e intenção. As técnicas utilizadas nesta forma são entrevista de grupo e entrevista individual;

- Não estruturado disfarçado: cria-se uma situação e encorajam-se os respondentes a exporem livremente dados sobre crença, sentimentos, personalidade, necessidades emocionais e seus conflitos interiores;

- Estruturado disfarçado: os entrevistados são solicitados a memorizar e, em seguida, a discorrer sobre um tópico determinado. As respostas são analisadas e conclusões são auferidas sobre a natureza do respondente conforme suas lembranças, crenças e sentimentos manifestados em relação ao tópico.

A atividade de pesquisa de marketing consiste em realizar medições (ex. medir quantos consumidores preferem um produto ao outro, atitudes, percepções) e, para isto, é necessário desenvolver instrumentos adequados para que as medidas realizadas tenham confiabilidade e validade. $O$ processo de medição consiste em associar números a um objeto, que, segundo uma regra estabelecida, possa representar as quantidades de suas características ou atributos.

Há quatro escalas básicas de medição, nominal, ordinal, intervalo e razão (Anexo C). A medição de atitudes é complexa, pois envolve medir algo que somente existe na mente das pessoas, não sendo diretamente observável (Mattar, 1997). Uma técnica proposta é a de auto-relato que é a mais utilizada em pesquisa de marketing para medição de atitudes. Consiste em solicitar às pessoas que respondam a um questionário contendo questões a respeito de suas atitudes. Para esta técnica, existem várias escalas de medição desenvolvidas, são elas: 
Escalas nominais: corresponde à associação de números às respostas com o objetivo de identificar categorias de resposta, facilitar a digitação, o processo e análise dos dados. Ex. (1) Sim (2) Não (3) Não sei;

Escalas de avaliação: pode ser gráfica, verbal ou itemizada. Na forma gráfica a pessoa deve associar as opções de resposta, desde o extremo mais favorável ao menos favorável, por figuras que representam categorias ordenadas; $\mathrm{Na}$ forma verbal há opções de resposta, desde o extremo mais favorável até o extremo mais desfavorável, pela ordenação e identificação das categorias através de expressões verbais; $\mathrm{Na}$ forma itemizada o entrevistado é solicitado a escolher uma categoria dentre várias categorias de expressões verbais de opiniões sob determinado tópico, formando uma escala, desde opinião mais desfavorável até a mais favorável.

Escalas de ordenação: solicita-se ao respondente que ordene ou classifique os objetos de acordo com sua atitude em relação a eles $\left(1^{\circ}, 2^{\mathrm{a}}\right.$...lugar). A restrição é que esta escala não permite determinar a distância entre as preferências.

Escalas comparativas: solicita-se ao respondente que expresse sua atitude mediante comparação com um padrão de referência estabelecido (X é pior/melhor/igual a Y).

Escalas de comparacão pareada: solicita-se ao respondente comparar várias marcas em conjunto de vários objetos de cada vez. $\mathrm{O}$ respondente deve comparar todos os possíveis pares de objetos do conjunto apresentado.

Escala de diferencial semântico: solicita-se ao respondente avaliar determinado objeto num conjunto de escalas bipolares de sete pontos. Ex.: grande/pequeno, justo/injusto....

Escala Stapel: é uma modificação da escala de diferencial semântico no sentido em que os pontos da escala são representados por números e a escala possui dez pontos. 
Escalas indiretas: combinam um conjunto de respostas dos entrevistados em relação ao objeto em questão, para determinar qual a sua posição na escala de atitudes desenvolvida. Geralmente são utilizadas em questões controversas ou que envolvam exposição de valores e atitudes em relação a assuntos considerados íntimos sendo, nesses casos, vantajosas pois os pesquisados podem não ser sinceros se responderem à escala direta.

As perguntas podem ser redigidas de duas formas (Mattar, 1998):

\section{Abertas}

Vantagens: influencia menos, não exige muito tempo de preparação, possibilita comentários importantes, estabelece um relacionamento com o respondente.

Desvantagens: maior tempo e custo para sua interpretação, grande potencial de viés quando aplicadas em forma de entrevistas, dificuldade de redação para alguns.

\section{Fechadas}

- Dicotômicas:

Vantagens: fácil e rápida aplicação, pouca possibilidade de erro;.

Desvantagens: pode apresentar erro de medição e erros sistemáticos.

- Escolha múltipla:

Vantagens: fácil e rápida de processar e analisar, pouca possibilidade de erros.

Desvantagens: exige tempo de preparação para que todas as opções sejam apresentadas, sem o que pode ser introduzido um viés.

- Escala: varia de acordo com as escalas acima citadas. 


\subsection{Pesquisa de Marketing}

A pesquisa de marketing aplicada às empresas e ao canal de distribuição foi realizada através de pesquisa exploratória - levantamento de campo, por questionários via correio, entrevistas e levantamento bibliográfico. O projeto de pesquisa foi ocasional, sendo medido uma única vez no tempo. Os dados primários levantados através de questionário foram formatados na forma estruturado não disfarçado.

Os dados secundários foram coletados em empresas, publicações, além de informações do sindicato das empresas farmacêuticas veterinárias e do governo.

As perguntas foram formuladas de forma fechada, múltipla escolha. Utilizaram-se escalas nominais e escalas de ordenação, para mensurar a preferência dos consumidores sob a perspectiva das empresas e do canal de distribuição.

\subsubsection{Empresas}

Dentre as 25 maiores empresas farmacêuticas veterinárias, 11 foram entrevistadas ou tiveram o questionário respondido via fax. São elas: Bayer, Boehringer, Elanco, Fort Dodge, Merial, Novartis, Pearson, Pfizer, Schering, Vallée e Virbac. Procurou-se direcionar os questionários aos profissionais envolvidos na gerência de produtos antiparasitários e antibióticos. O questionário aplicado às empresas foi mais extenso quando comparado ao questionário aplicado ao canal de distribuição, já que era possível o controle da qualidade das respostas.

\subsubsection{Canal de distribuị̧ão}

O questionário para este agente foi formatado através de três pré-testes aplicados na cidade de São Paulo, buscando-se minimizar problemas de mal entendimento das questões. Depois de formatados, os questionários foram enviados pelo correio, seguindo em anexo envelope selado, como forma de incentivar a resposta.

Estima-se que haja no Brasil, aproximadamente, 22.000 casas agropecuárias, 1.500 revendas de cooperativas e 200 grandes atacadistas/distribuidores. Não há dados 
tabulados disponíveis sobre a distribuição dessas empresas nas diferentes regiões brasileiras.

Foram enviados pelo correio 339 questionários, dos quais 15 eram para distribuidores/atacadistas, 20 para revendas de cooperativas e 304 para revendas agropecuárias. A amostragem ocorreu a partir da lista do SINDAN. Não houve amostragem aleatória por dois motivos: impossibilidade de se obter uma lista das casas agropecuárias por região e por não haverem dados disponíveis sobre a significância das regiões nas vendas por categorias de produtos.

Dos 339 questionários enviados, 127 foram para o Sudeste, 87 para o Sul, 99 para o Centro Oeste, 23 para o Nordeste e 3 para o Norte, segundo cadastro SINDAN. Os resultados foram apresentados de duas formas: distribuição de freqüência e medida de tendência central - moda.

\subsubsection{Erros teóricos na pesquisa}

Segundo a metodologia de análise dos possíveis erros de ocorrerem numa pesquisa de marketing proposta por Aaker et al. (1997), foram previamente identificados os possiveis erros não amostrais que poderiam ter ocorrido na pesquisa, são eles:

A. Erros no desenho da pesquisa:

- Erros de seleção: ocorre quando a amostragem é não probabilística e não é representativa da população. Neste caso, a amostragem partiu da lista do SINDAN, sendo está considerada pela mesma representativa da população.

B. Erros de respostas: quando o entrevistado responde incorretamente ao questionário intencionalmente ou não. Pode ocorrer por falta de entendimento ou por ser um questionário entediante. Visando minimizar estes erros pré-testes foram previamente aplicados buscando formatar os questionários de forma simples e compreensível.

C. Erros de não resposta: ocorre nos casos de não se conseguir entrar em contato com a amostra selecionada ou de essa não responder ao questionário. Neste caso, o erro foi 
minimizado enviando em anexo ao questionário envelope selado para resposta dos canais de distribuição.

\subsection{Estrutura do texto}

O texto está estruturado em três partes. A primeira, enquadramento teórico, objetiva rever o conceito de canal de distribuição e discutir a sua importância no presente trabalho para a compreensão das transações que ocorrem neste mercado e no processo de decisão de compra.

A segunda parte, resultados da pesquisa de campo - descrição do mercado, dos canais e transações, tem por objetivo caracterizar o ambiente competitivo das industrias farmacêuticas veterinárias utilizando como referencial teórico a análise do ambiente competitivo proposto por Aaker et. al (1997).

A terceira parte apresenta os resultados e discussão da pesquisa de campo sobre percepção da demanda, expostos em três sub-ítens. O primeiro e o segundo sub-ítem apresentam e discutem os resultados da pesquisa de campo obtidos a partir dos questionários aplicados junto às empresas farmacêuticas veterinárias e junto ao canal de distribuição. $\mathrm{O}$ terceiro aborda a comunicação utilizada pelas empresas e discute a percepção dos canais de distribuição sobre a eficácia desta comunicação. 


\section{ENQUADRAMENTO TEÓRICO}

\subsection{Canais de distribuição}

Neste capítulo, procura-se rever o conceito de canal de distribuição e como este assunto é tratado na literatura. Com esta finalidade utilizou-se a pesquisa realizada por Neves (1999) sobre canais de distribuição e a abordagem da vantagem competitiva proposta por Porter (1992).

Neves (1999) realizou uma extensa revisão da literatura sobre canais de distribuição e discutiu o papel destes canais como uma variável do composto mercadológico que oferece meios de se obterem vantagens competitivas sustentáveis e não serem facilmente copiados pelos concorrentes.

Segundo Rosembloon, citado por Neves (1999), conseguir vantagens através de produto, preço e promoção está cada vez mais difícil. No produto, a transferência de tecnologia entre empresas e a competição global possibilitam que empresas competidoras consigam igualdade de condições em design, atributos e qualidade. Em preços, a globalização possibilita condições de oferta aos menores preços possíveis.

Nas comunicações, o impacto está reduzido decorrente do excesso de propagandas impostos diariamente à população. Somente os canais de distribuição oferecem condições de serem considerados como uma vantagem competitiva sustentável por exigirem um planejamento de implantação, de organização e de relacionamento interpessoais de longo prazo.

Para Stem, citado por Neves (1999), os canais de distribuição podem ser vistos como um conjunto de organizações interdependentes envolvidas no processo de tomar o produto ou serviço disponível para consumo ou uso. Têm a função de satisfazer a demanda através de produtos e serviços no local, em quantidade, qualidade e preço 
correto, assim como estimular a demanda através de atividades promocionais dos componentes ou equipamentos atacadistas, varejistas, representantes e outros.

Segundo este mesmo autor, os canais de distribuição são maneiras de desenhar, desenvolver e manter relacionamentos entre os participantes do canal de tal forma que vantagens competitivas sustentáveis para as empresas devem ser obtidas. Justifica o aparecimento de canais de distribuição pela necessidade de aumentar a eficiência nos processos de troca, minimizar a discrepância em suprimentos e de facilitar do processo de busca.

Para Kotler (1994), os canais de distribuição têm por função trabalhar como intermediários para colocar os bens de uma empresa no mercado. $O$ uso de intermediários aumenta a eficiência de distribuição, pois torna os bens amplamente disponíveis e acessíveis aos mercados alvo, já que, através de seus contatos, experiências, especializações e escalas de operação fornecem à empresa mais do que ela pode alcançar atuando sozinha. Além disso, os intermediários facilitam o fluxo de bens e serviços, estabelecendo um ponte entre o suprimento de bens e os serviços gerados pelo produtor e os produtos exigidos pelos consumidores.

Ainda segundo Kotler, as principais funções que precisam ser desempenhadas pelos canais de distribuição são coleta e disseminação de informações dos consumidores atuais e potenciais, concorrentes e outros agentes, além de buscarem encontrar um acordo final sobre o preço e de outros termos relativos à oferta, comunicarem a intenção de compra ao fabricante, armazenarem e movimentarem o produto até o consumidor final.

Para Porter (1992), o modo como são executadas as atividades das empresas em relação aos canais afeta o custo e o desempenho das atividades de uma empresa e vice versa. Tais canais executam atividades como venda, publicidade e exposição que podem substituir ou complementar as atividades da empresa. Desta forma, a coordenação e otimização conjunta com os canais podem reduzir o custo ou intensificar a diferenciação. Os canais de distribuição, por apresentarem (1) economias diferentes das da indústria, (2) conferirem um alto impacto em potencial de diferenciação e (3) representarem um proporção significativa crescente nos custos, oferecem argumentos para que sejam considerados como atividade que confere vantagens competitivas. 
Ainda presente na revisão bibliográfica efetuada por Neves op. cit. as premissas assumidas para justificarem a presença dos canais de distribuição são que eles podem aumentar a eficiência do processo, ajustam a discrepância da oferta no processo de suprimento, principalmente através da homogeneização da oferta, minimizam os custos da distribuição através da rotinização das transações, facilitam o processo de busca, possibilitam o contato com consumidor antes, durante e após as vendas além de possibilitarem a especialização das atividades.

\subsection{Transações e processos de decisão de compra}

Segundo Porter (1992) toda empresa é uma reunião de atividades que são executadas para projetar, comercializar, entregar e sustentar seu produto. Todas estas atividades podem ser representadas, fazendo-se uso de uma cadeia de valores. Porter conceitua cadeia de valores como um instrumento básico para análise das fontes da vantagem competitiva de uma empresa. Ela desagrega uma empresa nas suas atividades de relevância estratégica para que se possa compreender o comportamento dos custos e as fontes existentes e potenciais de diferenciação.

A cadeia de valores não é uma coleção de atividades independentes, e sim um sistema de atividades interdependentes. As atividades de valor estão relacionadas por meio de elos que são relações entre o modo como uma atividade de valor é executada e o custo ou desempenho de uma outra. Tais elos podem resultar em vantagens competitivas de duas formas: otimização e coordenação. Embora, dentro da cadeia de valores sejam cruciais para a vantagem competitiva, os elos normalmente são sutis e passam despercebidos.

Em geral, a exploração dos elos exige informações ou fluxos de informações que permitam a otimização ou a coordenação. Os elos entre a cadeia de uma empresa e as cadeias de valores dos canais denominam-se elos verticais e o modo como são executados afeta o custo ou o desempenho das atividades de uma empresa.

A diferenciação de uma empresa pode ser alcançada através de várias atividades por ela exercidas, uma das formas de se obter singularidade é a seleção e coordenação com os canais de distribuição. Os elos com os canais podem levar à singularidade a partir do 
momento que as empresas não só treinam os canais em vendas e em outras práticas comerciais, como também aumentam os esforços de vendas conjuntos e subsidiam investimentos dos canais em pessoal, instalações e na execução de atividades adicionais. $O$ canais de distribuição também servem como agentes capazes de elevar o desempenho do comprador, considerando-se que são fatores de escopo competitivo vertical sobre a cadeia de valores. Os escopos competitivos têm quatro dimensões:

- Escopo do segmento: a variedade de produtos produzidos e de compradores atendidos.

- Escopo vertical: até que ponto as atividades são executadas internamente ao invés de por empresas independentes, considerando-se tanto aspectos fisicos como atividades desempenhadas.

- Escopo geográfico: a variedade de regiões, países ou grupos de países em que uma empresa compete com uma estratégia coordenada.

- Escopo da indústria: a variedade de indústria afins em que a empresa compete com uma estratégia coordenada.

O escopo vertical define a divisão de atividades entre uma empresa e seus fornecedores, canais e compradores. Os canais podem desempenhar muitas funções de distribuição, assistência técnica e marketing no lugar da empresa. Se a integração reduz ou não o custo ou acentua a diferenciação, depende da empresa e da atividade envolvida. 


\section{RESULTAdOS DA PESQUISA DE CAMPO: DESCRIÇÃO DO MERCADO, CANAIS E TRANSAÇÕES}

\subsection{Característica da Indústria: Ambiente Competitivo}

O capítulo que se segue visa prover o leitor de características do mercado consumidor de medicamentos veterinários, sua dinâmica e tendências.

\subsubsection{O setor farmacêutico veterinário}

O setor farmacêutico veterinário faz parte da cadeia produtiva do setor químico, que é formada basicamente por quatro segmentos: commodities ou química pesada (inorgânica e orgânica), química fina, paraquímica e farmácia. Os dois primeiros formam a "química de base", os dois últimos formam as chamadas especialidades (Figura 2). 
Figura 2 - Setor Químico

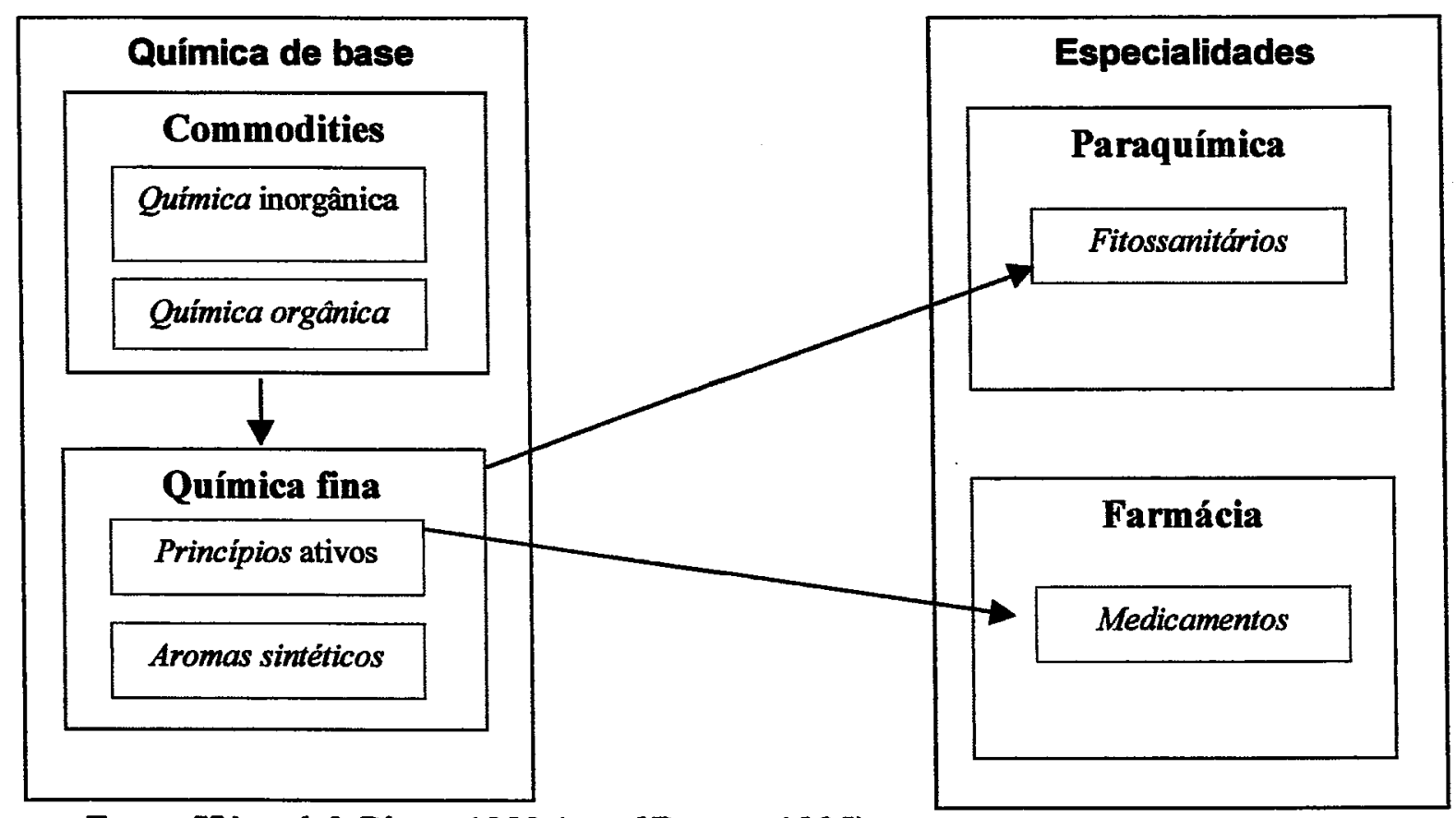

Fonte: Héraud \& Pivot, 1989 (apud Bruno, 1995)

Uma característica do setor químico é que este pode ser, ao mesmo tempo, gerador de produtos finais e de produtos intermediários.

Os produtos químicos podem ser classificados de acordo com sua escala de produção, tipo de produto (commodities ou diferenciados) e o valor conferido aos diferentes produtos (Tabela 1). 
Tabela 1 - Classificação dos produtos químicos (em função da escala de produção, produtos obtidos e valor agregado).

\begin{tabular}{|l|l|l|l|}
\hline \multicolumn{1}{|c|}{ Setor } & \multicolumn{1}{|c|}{ Química Pesada } & \multicolumn{1}{c|}{ Química Fina } & \multicolumn{1}{c|}{ Especialidades } \\
\hline Produção anual & $\begin{array}{l}\text { Elevada escala de } \\
\text { produção }\end{array}$ & $\begin{array}{l}\text { Baixa escala de } \\
\text { produção }\end{array}$ & Pequena quantidade \\
\hline Produtos & $\begin{array}{l}\text { Produtos } \\
\text { indiferenciados } \\
\text { (commodities) e } \\
\text { diferenciados (pseudo- } \\
\text { commodities) }\end{array}$ & $\begin{array}{l}\text { Produtos } \\
\text { indiferenciados }\end{array}$ & $\begin{array}{l}\text { Medicamentos e } \\
\text { fitossanitários }\end{array}$ \\
\hline Valor & Baixo valor agregado & Maior valor agregado & $\begin{array}{l}\text { Alto valor agregado, } \\
\text { geralmente vendidos } \\
\text { sob uma marca } \\
\text { comercial }\end{array}$ \\
\hline Exemplo & $\begin{array}{l}\text { Commodities: Ácido } \\
\text { sulfúrico, etileno } \\
\text { Pseudo-commodities: } \\
\text { Polietileno, } \\
\text { polipropileno }\end{array}$ & $\begin{array}{l}\text { Ácido salicílico, } \\
\text { vitamina C, corantes } \\
\text { alimentares }\end{array}$ & $\begin{array}{l}\text { Aspirina®, Keflex } \circledast, \\
\text { Buscopan® }\end{array}$ \\
\hline
\end{tabular}

Fonte: Bruno, 1995

$\mathrm{Na}$ indústria farmacêutica pode-se inserir à cadeia mais um setor, denominado de produtos biológicos, que se caracteriza por utilizar processos biotecnológicos na produção. Esses processos são a principal rota de obtenção de vacinas e produtos para diagnóstico, mas também integram a rota de alguns antiparasitários, antibióticos, vitaminas e suplementos nutricionais e energéticos (Figura 3). A indústria farmacêutica, através dos produtos químicos e dos processos de biotecnologia produz os semisintéticos, segmento que se caracteriza por utilizar moléculas biológicas e modificá-las através de tratamento químico. Um exemplo é a ivermectina, produzida a partir da avermectina (substância sintetizada pelo fungo Streptomyces Avermitilis). 
Figura 3 - Rota de obtenção de produtos biológicos

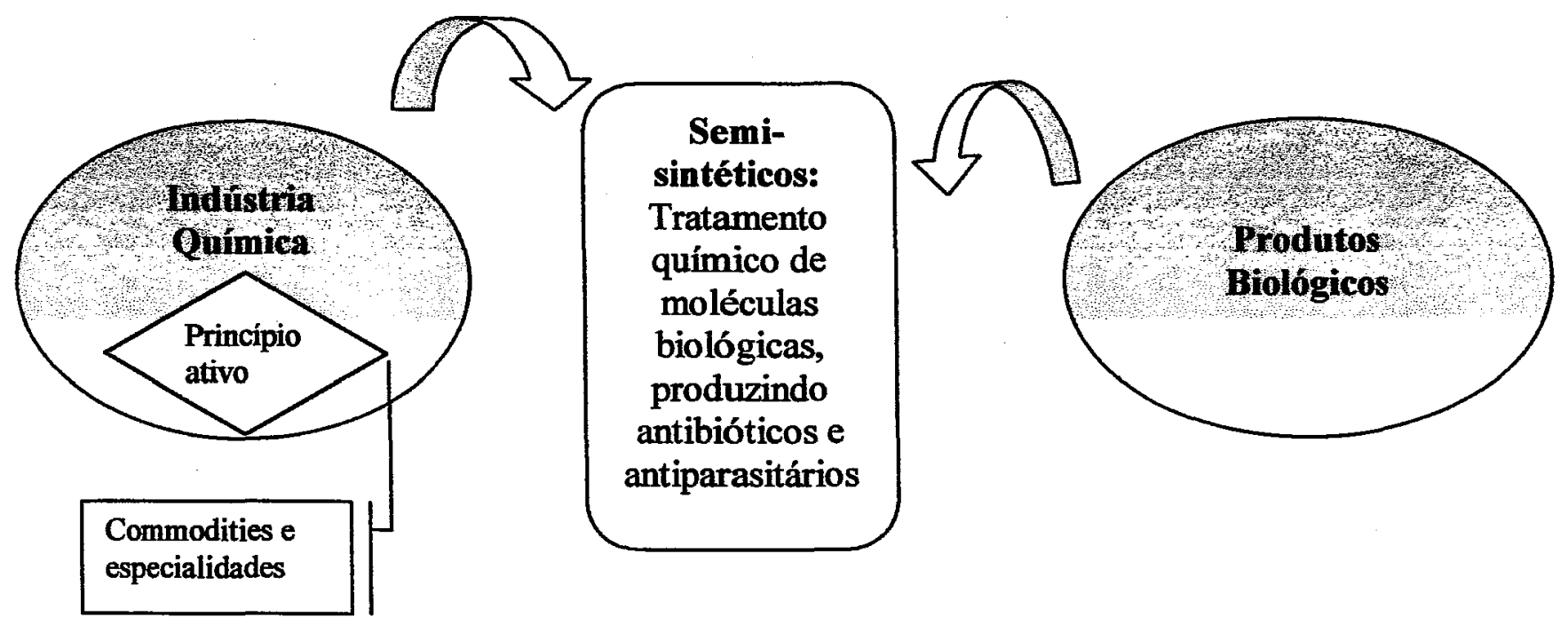

Fonte: Entrevista com Waack, R. (Boehringer Ingelheim), 1998

A indústria farmacêutica veterinária está inserida no sub-setor das especialidades, caracterizada por fabricar produtos de maior valor agregado, diferenciados e normalmente vendidos sob uma marca comercial. Os processos de fabricação são caracterizados por ciclos longos e de baixa flexibilidade operacional (Wood et al., 1994).

A indústria farmacêutica, de um modo geral, tem a tecnologia como diferencial competitivo e suas principais diferenças em relação às indústrias de outros setores são a pesquisa e desenvolvimento, o marketing e as vendas (Bruno, 1995). O ambiente competitivo tende à concentração e ao aumento do grau de diferenciação dos produtos além de apresentar fortes barreiras de entrada decorrente dos investimentos necessários em tecnologia. 


\subsubsection{Concentração de mercado}

O setor farmacêutico está entre os setores nos quais a tecnologia exerce papel importante no desempenho econômico das empresas. Baseado na ciência, caracteriza-se por investimentos vultosos em pesquisa e desenvolvimento (Tabela 2), justificando a forte tendência de concentração de mercado observada no Brasil e no mundo (Tabela 3).

Tabela 2 - Despesas com P\&D (de algumas empresas por linha de produto principal)

\begin{tabular}{|l|c|c|}
\hline $\begin{array}{c}\text { Empresa especialidades } \\
\text { (P\&D/Vendas>10\%) }\end{array}$ & $\begin{array}{c}\text { Despesa P\&D/Vendas em } \\
1992 \%\end{array}$ & Variação 1991-1992\% \\
\hline Shering & 15,8 & $+6,1$ \\
\hline Hoffman - La - Roche & 15,4 & $+2,3$ \\
\hline Eli Lilly & 15,0 & $+12,0$ \\
\hline Pfizer & 11,9 & $+9,6$ \\
\hline Merck \& Co & 11,5 & $+0,2$ \\
\hline Cyanamid & 10,7 & $+8,9$ \\
\hline Ciba-Geigy* & 10,6 & $+2,1$ \\
\hline Sandoz & 10,4 & $+4,4$ \\
\hline
\end{tabular}

Fonte: Bruno, 1995

*Fusão em 1996 
Tabela 3 - Principais fusões e aquisições no setor farmacêutico veterinário

\begin{tabular}{|c|c|c|}
\hline Ano & Operação & Caracteristicas \\
\hline 1994 & $\begin{array}{l}\text { American Home compra a American } \\
\text { Cyanamid }\end{array}$ & \\
\hline 1994 & $\begin{array}{l}\text { Pfizer compra a SmithKline Beecham } \\
\text { saúde animal }\end{array}$ & \\
\hline 1994 & $\begin{array}{l}\text { Roche compra a área de saúde animal da } \\
\text { Syntex }\end{array}$ & Vendida por U $\$ 5,3$ bilhões \\
\hline 1994 & $\begin{array}{l}\text { Rhone-Poulenc e Merck formam uma } \\
\text { joint-venture na área de saúde animal e } \\
\text { atividade de genética aviária (Merial) }\end{array}$ & $\begin{array}{l}\text { Objetivo de formar um líder } \\
\text { veterinário global com vendas de U\$ } \\
1,7 \text { bilhões/ano }\end{array}$ \\
\hline 1996 & $\begin{array}{l}\text { Ciba e Sandoz se unem formando a } \\
\text { Novartis }\end{array}$ & Vendas anuais de U\$ 5 bilhões/ano \\
\hline 1997 & $\begin{array}{l}\text { Shering Plough compra a unidade } \\
\text { veterinária da Mallinckrodt }\end{array}$ & Vendida por U\$ 405 milhões \\
\hline 1997 & Fort Dodge compra a Solvay saúde animal & Vendida por U\$ 450 milhões \\
\hline 1998 & $\begin{array}{l}\text { American Home Product e a Monsanto } \\
\text { planejam se unir }\end{array}$ & $\begin{array}{l}\text { Negócios envolvendo U\$ } 23 \text { bilhões } \\
\text { vendas/ano nas áreas farmacêutica, } \\
\text { agrícola, saúde animal e nutricional. }\end{array}$ \\
\hline
\end{tabular}

Fonte: diversas

\subsubsection{Mercado de produtos veterinários}

$\mathrm{O}$ artigo $2^{\circ}$ do Decreto Federal n. 1.662, de 06/10/95 define produtos veterinários como "toda substância química, biológica, biotecnológica ou preparação manufaturada, cuja administração seja aplicada de forma individual ou coletiva, direta ou misturada com alimentos, destinada a prevenção, ao diagnóstico, a cura ou ao tratamento das doenças dos animais, incluindo os aditivos, suprimentos, promotores, melhoradores da produção animal, anti-sépticos, desinfetantes de uso ambiental ou equipamentos, pesticidas e todos os produtos que, utilizados nos animais elou no seu hábitat protejam, restaurem ou modifiquem suas funções orgânicas e fisiológicas. Compreendem-se, ainda, nesta definição, os produtos destinados ao embelezamento dos animais."

Os recursos econômicos mundiais gerados por este setor (excluindo os nutricionais) atingiram, em 1998, cerca de US\$ 11 bilhões anuais (Tabela 4), com uma taxa de 
crescimento de 1,4\% ao ano, abaixo, portanto, da taxa estimada para este setor de 3,6 \% ao ano até o ano 2000 (Walsh, 1997).

Tabela 4 - Crescimento do mercado mundial entre 1996 e 1997

\begin{tabular}{|l|c|c|c|}
\hline \multicolumn{1}{|c|}{ Área } & $\begin{array}{c}\text { Vendas em 1996 } \\
\text { (Milhóes de dblares) }\end{array}$ & $\begin{array}{c}\text { Vendas em 1997 } \\
\text { (Milhóes de dolares) }\end{array}$ & $\begin{array}{c}\text { Vendas em 1998 (Milhöes } \\
\text { de dólares) }\end{array}$ \\
\hline Fármacos & 8.517 & 8.690 & 8.764 \\
\hline Biológicos & 2.300 & 2.323 & 2.366 \\
\hline
\end{tabular}

Fonte: Animal Pharm of 1997 e Animal Pharm of 1998.

Define-se como fármaco (sinônimo de medicamento) qualquer substância química empregada num organismo vivo, visando obter efeitos benéficos à sua saúde. São substâncias químicas destinadas a curar, diminuir, prevenir e/ou diagnosticar as enfermidades (Spinosa et al, 1996). Há várias classes de fármacos químicos:

Fármacos $\begin{cases}\bullet & \text { Medicamentos para o Sistema Cardiovascular } \\ \bullet & \text { Medicamentos com ação no Sistema Respiratório } \\ \bullet & \text { Medicamentos com ação no Sistema Urinário } \\ \bullet & \text { Antimicrobianos: anti-sépticos, desinfetantes, antibióticos, agentes } \\ \text { antifúngicos e antivirais, antimicrobianos para mastite } & \\ \bullet & \text { Antiinflamatório: esteroidais e não esteroidais } \\ \bullet & \text { Parasiticidas } \\ \bullet & \text { Outros }\end{cases}$

Os produtos obtidos a partir de culturas celulares, por sua vez, são denominados biológicos, podendo ser:

Biológicos $\begin{cases}\bullet & \text { Antibióticos } \\ \bullet & \text { Vacinas } \\ \bullet & \text { Hormônios } \\ \bullet & \text { Outros }\end{cases}$

Os fármacos são produtos que podem ser estocados a seco por tempo determinado, enquanto as vacinas exigem uma rede de refrigeração para acondicioná-las.

Mundialmente, mercado de saúde animal segmenta-se em três grandes áreas: pecuária (bovinos, suínos e ovelhas), avicultura e animais de companhia (cães, gatos e cavalos). $O$ 
mercado de pecuária e avicultura, que juntos representavam $70 \%$ do total, em 1998 , apresentou uma queda de 0,9\% em 1998 (Tabela 5 e Tabela 6). No entanto, os animais de companhia aumentaram suas vendas em $9 \%$, compensando a queda ocorrida nas vendas nos outros segmentos.

Tabela 5 - Participação percentual nas vendas por espécie animal (no Brasil e no mundo)

\begin{tabular}{|l|c|c|c|}
\hline \multicolumn{1}{|c|}{$\begin{array}{c}\text { Espécie } \\
\text { Animal }\end{array}$} & $\begin{array}{c}\text { Distribuição de } \\
\text { vendas de produtos } \\
\text { veterinários no } \\
\text { Brasil }\end{array}$ & $\begin{array}{c}\text { Vendas em Milhöes de } \\
\text { dólares (incluindo } \\
\text { nutricionais) }\end{array}$ & $\begin{array}{c}\text { Participação } \\
\text { Mundial em \% nas } \\
\text { vendas }\end{array}$ \\
\hline Bovinos & $66,9 \%$ & 568,60 & $30 \%$ \\
\hline Ovinos & $1,2 \%$ & 10,00 & $10 \%$ \\
\hline Aves & $13,3 \%$ & 113,00 & $20 \%$ \\
\hline Suínos & $8,1 \%$ & 69,00 & $20 \%$ \\
\hline Eqüinos & $3,8 \%$ & 32,40 & $20 \%$ \\
\hline $\begin{array}{l}\text { Pequenos } \\
\text { Animais }\end{array}$ & $6,7 \%$ & 57,00 & $100 \%$ \\
\hline TOTAL & $100 \%$ & 850,00 & 100 \\
\hline
\end{tabular}

Fonte: Dados da Boehringer Ingelheim e SINDAN (1996)

Tabela 6 - Vendas por espécie no mundo

\begin{tabular}{|l|c|c|c|}
\hline & $\begin{array}{c}1997 \text { (vendas em } \\
\text { milhões de dólares) }\end{array}$ & $\begin{array}{c}1998 \text { (vendas em } \\
\text { milhões de dólares) }\end{array}$ & Variação em \% \\
\hline Pecuária & 6390 & 6230 & $-2,5 \%$ \\
\hline Avicultura & 1575 & 1600 & $1,6 \%$ \\
\hline Animais de companhia & 3135 & 3420 & $9,1 \%$ \\
\hline Mercado de saúde animal & 11100 & 11250 & $1,4 \%$ \\
\hline
\end{tabular}

Fonte: Wood Mackenzie, apud Sauer (1999)

O aumento da competição e a saturação de mercado são os principais fatores de perda de lucratividade. Nos países desenvolvidos, o aumento da lucratividade está ligado ao lançamento de novos produtos e expansão das oportunidades de negócios. Em 1998, o mercado pecuário apresentou queda decorrente da depressão que atingiu o mercado de suínos. É de consenso das grandes empresas mundiais que o mercado em geral tende a crescer entre 1 a $3 \%$ e que a suinocultura tenda a buscar recuperar sua performance. 
Os principais produtos comercializados mundialmente e no Brasil, de acordo com a revista Animal Pharm (apud Waack et al., 1994), estão representados na Tabela 7.

Tabela 7 - Participação dos produtos nas vendas mundiais e brasileiras

\begin{tabular}{|l|c|c|c|c|c|}
\hline & Nutricionais & Parasiticidas & $\begin{array}{c}\text { Vacinas } \boldsymbol{e} \\
\text { diagnósticos }\end{array}$ & $\begin{array}{c}\text { Anti } \\
\text { microbianos }\end{array}$ & Especialidades \\
\hline Mundial & $25 \%$ & $22 \%$ & $13 \%$ & $27 \%$ & $13 \%$ \\
\hline Brasil & $27,8 \%$ & $31,4 \%$ & $18,9 \%$ & $14,1 \%$ & $7,7 \%$ \\
\hline
\end{tabular}

Fonte: Dados da Boehringer Ingelheim e SINDAN, 1996

Em 1999, segundo dados da Wood Mackenzie (Sauer, 1999), a representatividade dos parasiticidas nas venda mundiais de medicamento aumentou, passando a representar $28 \%$ da vendas mundiais, Os biológicos e as especialidades também apresentaram aumento na representatividade, passando a representarem, respectivamente, $20 \%$ e $17 \%$ das vendas mundiais. Os antimicrobianos apresentaram queda, passando a representar $18 \%$, assim como houve queda na representatividade dos aditivos nutricionais, que passaram a representar $18 \%$.

Quanto às expectativas das indústrias em relação às categorias de produtos que mais crescerão durante esta década, vacinas, antiparasitários e antimicrobianos são os produtos que possuem o maior destaque. Acredita-se, também, que haverá um cruzamento da linha farmacológica humana com o desenvolvimento de medicamentos para uso animal, dada a similaridade das doenças, principalmente medicamentos de controle de afecções dolorosas e de melhorias das funções musculares.

Em 1998, os produtos que apresentaram maior crescimento foram os antiparasitários e os produtos voltados para animais de companhia. Nesse setor, os produtos de controle de pulga lideraram as vendas. Em países da América Latina e Sudoeste Asiático, espera-se que a venda de medicamentos para tais animais cresça, caracterizando uma expansão da demanda por aumento da renda da população, fator fortemente ligado a políticas macroeconômicas governamentais locais. Por outro lado, as vendas de antimicrobianos 
apresentaram queda, relacionada à tendência do aumento da prevenção, em detrimento aos métodos curativos.

\subsubsection{Evolução do setor no Brasil}

No começo dos anos oitenta, as vendas anuais brasileiras de produtos para saúde animal totalizaram um valor de US\$ 300 milhões. O Brasil, até então, apresentava fortes controles de preço, o que reduzia os lucros das empresas.

Nesse setor, os investimentos e o desenvolvimento de novas moléculas são altos, as perspectivas de retorno são de longo prazo e não há garantias de aceitabilidade por parte dos consumidores e autoridades. Ademais, a inexistência de uma lei de patentes, até 1996, não incentivava as empresas a investirem em tecnologia.

Em 1990, na época do Plano Collor, as vendas aumentaram de 404 milhões para 500 milhões de dólares (Tabela 8) em decorrência de vários fatores. $\mathrm{O}$ mais significativo foi a intensificação das campanhas de vacinação contra a febre aftosa e a liberação do preço da vacina. Por outro lado, nesta mesma época foi lançada a Ivermectina pela MSD Agvet, produto que, de acordo com alguns autores, representou o maior sucesso comercial de toda a história da saúde animal. Atingiram-se vendas superiores a US\$ 350 milhões anuais (Jones, apud Zylbersztajn, op. cit.).

Para Wesley \& Hicks (1992), no Plano Collor ocorreu a desregulamentação do mercado, além da maior especialização dos produtores e de quedas nas tarifas alfandegárias, o que possibilitou às empresas adquirirem matéria prima a preços mais competitivos. 
Tabela 8 - Vendas de produtos veterinários no Brasil de 1989 a 1997

\begin{tabular}{|l|c|l|}
\hline ANO & $\begin{array}{c}\text { Vendas em } \\
\text { Milhöes de } \\
\text { dólares }\end{array}$ & Evento \\
\hline 1989 & 404,7 & Plano Collor \\
\hline 1990 & 500,7 & \\
\hline 1991 & 481,4 & \\
\hline 1992 & 510,8 & \\
\hline 1993 & 613,1 & \\
\hline 1994 & 692,4 & Plano Real \\
\hline 1995 & 782,1 & \\
\hline 1996 & 827,6 & \\
\hline 1997 & 850,8 & \\
\hline
\end{tabular}

Fonte: SINDAN (Sindicato das Indústrias farmacêuticas veterinárias)

Após o Plano Real, o consumo de produtos veterinários cresceu com o aumento da renda per capita e o aumento no consumo de carnes e leite, o que estimulou o produtor a investir em saúde animal.

No Brasil o principal medicamento de vendas (excluindo aditivos) é o antiparasitário, que alcançou em 1997 um total de vendas de 266 milhões de dólares (Figura 4), tendo a bovinocultura maior representatividade nas compras, com mais de $60 \%$ do consumo de antiparasitários no Brasil (Figura 5). 
Figura 4 - Distribuição das vendas no Brasil (em milhões de dólares)

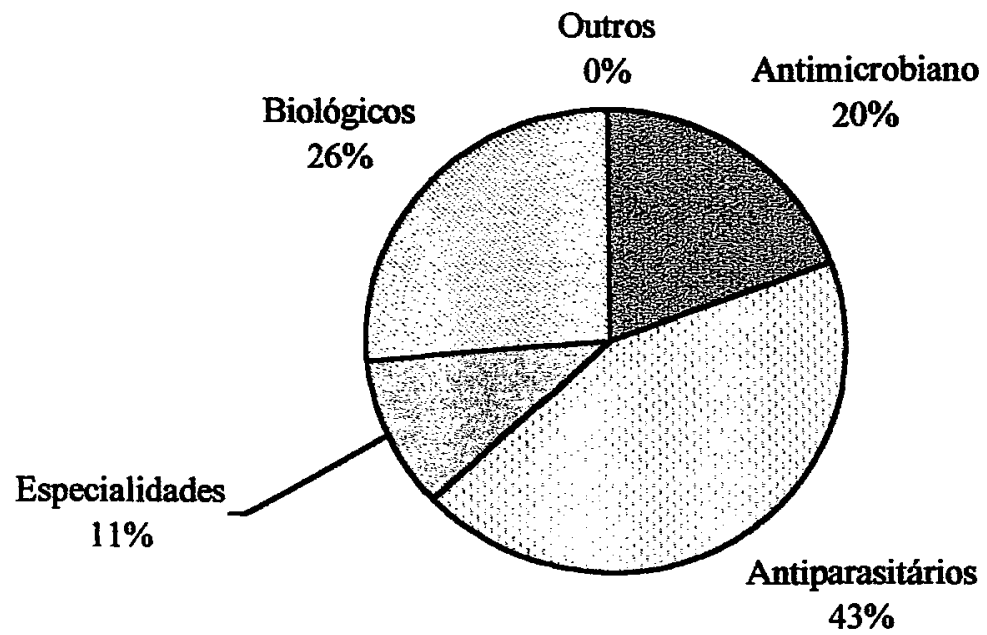

Fonte: SINDAN,1997

Figura 5 - Distribuição das vendas no Brasil para cada espécie animal

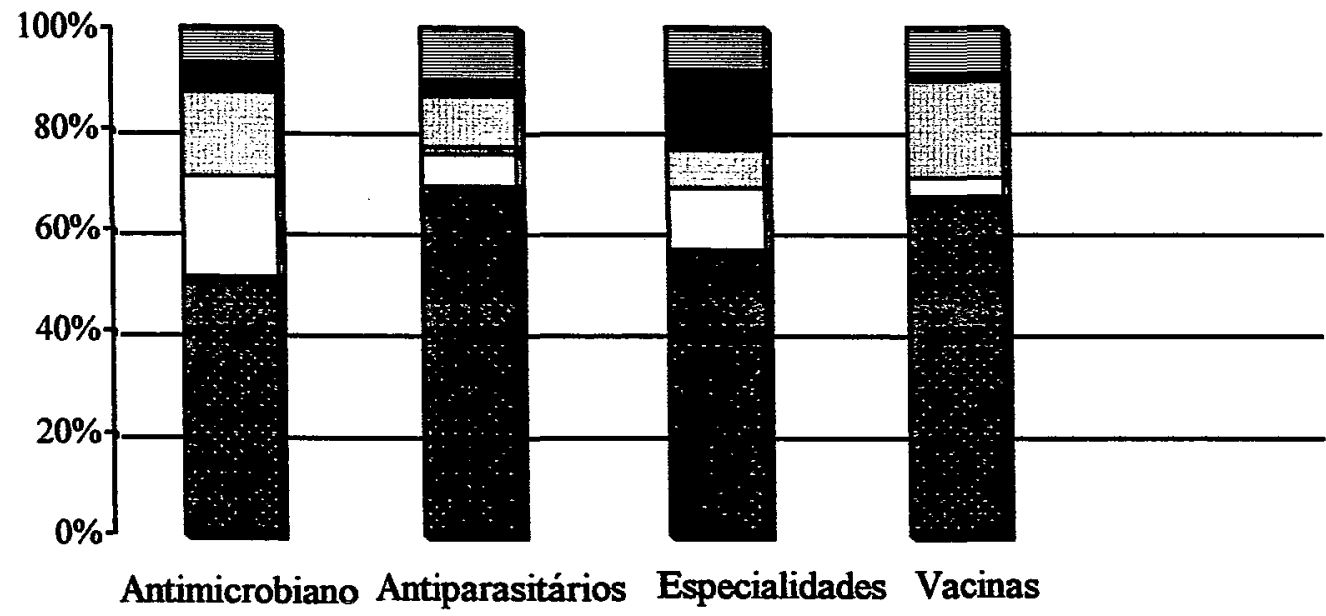

Bovinos $\square$ Suínos Ovinos $\square$ Aves Eqüinos 首Peq. Animais

Fonte: SINDAN, 1997 
O Brasil se destaca como sendo o terceiro maior mercado mundial de produtos veterinários, com cerca de $5 \%$ do total comercializado em 1997 e com vendas totais de 828 milhões dólares/ano (Tabela 9).

Tabela 9 - Principais países nas vendas de produtos veterinários

\begin{tabular}{|l|c|}
\hline \multicolumn{1}{|c|}{ PAÍS } & Vendas em milhões de dólares \\
\hline E.U.A & 3.296 \\
\hline Japão & 936 \\
\hline Brasil & $\mathbf{8 2 8}$ \\
\hline França & 692 \\
\hline Alemanha & 532 \\
\hline Reino Unido & 528 \\
\hline Espanha & 325 \\
\hline Canadá & 256 \\
\hline Itália & 221 \\
\hline México & 196 \\
\hline Países baixos & 171 \\
\hline Argentina & 150 \\
\hline Dinamarca & 72 \\
\hline
\end{tabular}

Fonte: Animal Pharm Review of 1997

Como se pode notar, a principal demanda de produtos no Brasil está relacionada a vacinações, principalmente contra febre aftosa, e condições climáticas brasileiras: alta temperatura $\mathrm{e}$ alta incidência de chuva num período determinado, causando $o$ aparecimento e a proliferação de inúmeras doenças (Gráfico 1). 
Gráfico 1 - Vendas brasileiras de produtos veterinários (em milhões de dólares de janeiro de 1995 a junho de 1997)

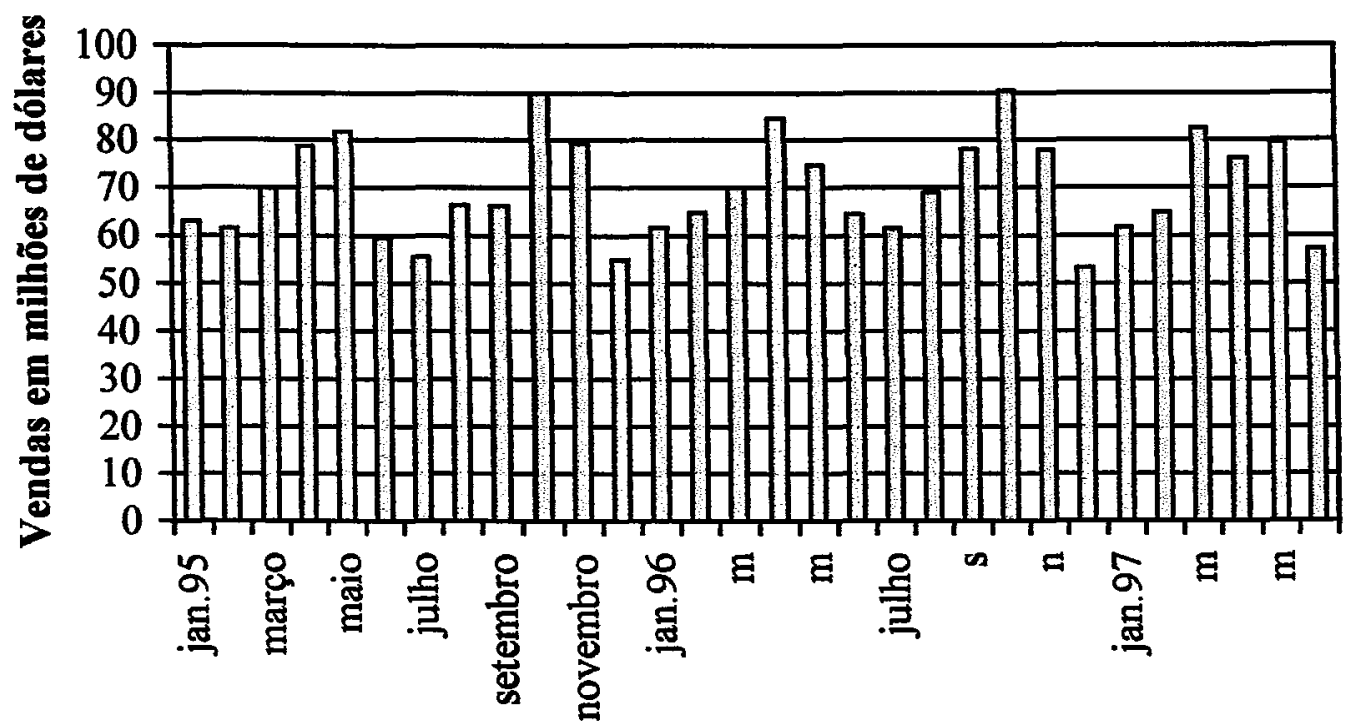

Tempo

\section{Fonte: SINDAN}

A bovinocultura é representativa nas vendas de medicamentos veterinários no Brasil, sendo as vacinas e antiparasitários os produtos mais comercializados. A sazonalidade das vendas explica-se pela época de vacinação contra aftosa, que é fevereiro, maio e novembro (até 1996 era abril/outubro), período no qual os pecuaristas aproveitam para concentrar suas atividades, administrando vermífugo em todo o rebanho e vacinando os animais mais jovens contra clostridioses e brucelose.

\subsubsection{Antiparasitários}

Os helmintos (vulgo parasitas) constituem um grave problema sócio econômico, pela alta prevalência entre animais domésticos e silvestres e por alguns deles serem considerados zoonoses. $\mathrm{O}$ controle dos parasitas é baseado na utilização de antihelmínticos/antiparasitários (forma predominante) e por controle biológico e ambiental. 
Os antiparasitários dividem-se em 3 categorias: os de ação interna (endoparasiticidas), os de ação externa (ectoparasiticidas) e os de dupla ação (endectocidas). Os anti-helmínticos classificam-se em três grupos: compostos inorgânicos, compostos orgânicos e compostos orgânicos sintéticos.

Os prejuízos decorrentes das parasitoses nos animais caracterizam-se por perda de peso, crescimento tardio e predisposição a outras doenças. A utilização dos parasiticidas foi extremamente benéfica para controlar os efeitos da infestação e levar ao aumento da produtividade animal, porém seus benefícios levaram ao uso indiscriminado, com dosagens incorretas, causando o aumento das taxas de aquisição de resistência dos principais parasitas.

Os antiparasitários correspondem a $43 \%$ das vendas de medicamentos veterinários no Brasil. Os antiparasitários destinados à pecuária têm curta vida útil, decorrente da rápida aquisição de resistência dos agentes patogênicos. Estratégias de lançamento, acompanhamento da eficiência dos produtos no campo, retiradas de produtos do mercado em momentos adequados e relançamentos são elementos fundamentais para o sucesso dos antiparasitários no mercado. Em 1998, o mercado de parasiticidas apresentou um crescimento significativo, liderado principalmente pela categoria de produtos antipulgas para animais de companhia.

\subsubsection{Antimicrobianos}

Os antimicrobianos correspondem a $20 \%$ das vendas de medicamentos veterinários no Brasil. Deste total grande parte são administrado oralmente ou de forma injetável. Em menor proporção são administrados intramamáriamente e de outras formas (ex. vela uterina).

O principal uso do antimicrobiano é combater os microorganismos, agentes que podem ser específicos ou inespecíficos. Os primeiros atuam sobre microorganismos responsáveis pelas doenças infecciosas que acometem os animais: os quimioterápicos e os antibióticos. Os antimicrobianos inespecíficos, por sua vez, atuam sobre 
microorganismos em geral, quer sejam patogênicos, ou não. Pertencem a este grupo os anti-sépticos e os desinfetantes.

Originalmente, a definição original de antibiótico é substância química produzida por microorganismos que têm a capacidade de, em pequenas doses, inibir o crescimento ou destruir microorganismos causadores de doenças. Posteriormente, essa definição se ampliou introduzindo-se o conceito de síntese laboratorial parcial ou total: antibióticos, antibióticos biossintéticos, antibióticos semi-sintéticos e sintobióticos. Os antimicrobianos são agrupados em duas categorias: os de uso terapêuticos e os de uso profilático.

A discussão recente, envolvendo o uso de antimicrobianos como aditivos em ração, questiona a possibilidade de surgir resistência dos microrganismos aos antibióticos nos seres humanos. Esse assunto é controverso, dado que $\mathbf{9 5 \%}$ das notícias divulgadas a este respeito são elaboradas por meio de comunicação leiga, havendo um sensacionalismo sobre este assunto (Yeo, 1998). Estima-se que, nos Estados Unidos, aproximadamente $45 \%$ dos antibióticos sejam usados em formulações de rações para animais, diminuindo a incidência de doenças e aumentam o ganho de peso. Estima-se ainda que, quase $80 \%$ das aves, $75 \%$ dos suínos, $60 \%$ dos bovinos de corte e $75 \%$ das vacas leiteiras já receberam suplemento com antibióticos em sua composição (Wade \& Barkley, 1992).

Na Suécia, o modelo de produção animal baniu o uso de antibióticos como aditivo alimentar por causa da possibilidade de resistência cruzada, sendo usados somente em casos de prescrição médica veterinária. Estima-se que até 2001 todos antibióticos usados na ração animal deixarão de ser autorizados na Europa, levando as empresas a buscarem o desenvolvimento de formas alternativas de promotores de crescimento na dieta animal. Nos EUA, pressões sociais estão surgindo para impedirem o uso de antibióticos nas rações animais, assim como na Europa. Um exemplo típico é a requisição do Centro de Ciência no Interesse Público junto ao FDA (Food and Drug Administration) para a remoção de sete antibióticos de uso na agricultura, incluindo: penicilina, tetraciclina, eritromicina, lincomicina, tilosina e virginiamicina. A alegação é a de que tais antibióticos são usados como primeira escolha em tratamentos em humanos e que o uso disseminado na agricultura está selecionando formas resistentes de patógenos. 


\subsubsection{Principais empresas do setor}

As maiores corporações mundiais do ramo farmacêutico veterinário apresentam-se na Tabela 10 (Waack \& Neves, 1995).

Uma característica desse setor é a constante alternância de posição de liderança no mercado, decorrente do alto custo de $\mathrm{P} \& \mathrm{D}$, da grande onda de fusão e aquisição e da formação de alianças estratégicas.

Tabela 10 - Ranking das dez maiores empresas mundiais do setor farmacêutico veterinário em 1994 e 1998

\begin{tabular}{|c|c|c|c|c|c|c|}
\hline EMPRESA & $\begin{array}{c}\text { RANKING EM } \\
1994\end{array}$ & $\begin{array}{c}\text { FATUR } \\
\text { (EMUS\$ } \\
1.000)\end{array}$ & $\begin{array}{c}\text { RANKING EM } \\
1997\end{array}$ & $\begin{array}{c}\text { FATUR } \\
\text { (EMUS\$ } \\
1.000)\end{array}$ & $\begin{array}{c}\text { RANKING EM } \\
1997\end{array}$ & $\begin{array}{c}\text { FATUR. } \\
\text { (EMUS\$ } \\
1.000)\end{array}$ \\
\hline $\begin{array}{l}\text { Hoffiman La } \\
\text { Roche }\end{array}$ & $1^{\circ}$ & 1.100 & $1^{\circ}$ & 1.603 & $1^{\circ}$ & 1.549 \\
\hline $\begin{array}{l}\text { Rhone } \\
\text { Poulenc }\end{array}$ & $2^{\circ}$ & 932 & $2^{\circ}$ & 1.480 & $2^{\circ}$ & 1.520 \\
\hline Merck AgVet & $3^{\circ}$ & 695 & & & & \\
\hline $\begin{array}{l}\text { SmithKline } \\
\text { Beecham }^{(2)}\end{array}$ & $4^{\circ}$ & 614 & ----- & ------- & ----- & ------ \\
\hline Bayer & $5^{\circ}$ & 605 & $4^{\circ}$ & 897 & $4^{\circ}$ & 1.041 \\
\hline $\begin{array}{l}\text { Mallinckrodt } \\
\text { (Pitman) (3) }\end{array}$ & $6^{\circ}$ & 592 & ------- & - & ------ & ------ \\
\hline Pfizer & $7^{\circ}$ & 578 & $3^{\circ}$ & 1.307 & $3^{\circ}$ & 1.330 \\
\hline Basf & $8^{\circ}$ & 570 & $7^{\circ}$ & 684 & $7^{\mathbf{o}}$ & 757 \\
\hline Hoechst & $9^{\circ}$ & 444 & $11^{\circ}$ & 497 & $11^{\circ}$ & 516 \\
\hline Elanco & $10^{\circ}$ & 439 & $10^{\circ}$ & 580 & $9^{\circ}$ & 620 \\
\hline RPAN & $*$ & & $5^{\circ}$ & 731 & $6^{\circ}$ & 777 \\
\hline Fort Dodge & $*$ & & $6^{\circ}$ & 730 & $5^{\circ}$ & 785 \\
\hline $\begin{array}{l}\text { Shering } \\
\text { Plough }\end{array}$ & * & & $8^{\circ}$ & 655 & $10^{\circ}$ & 609 \\
\hline Novartis (4) & * & & $9^{\circ}$ & 645 & $8^{\circ}$ & 647 \\
\hline
\end{tabular}

Fonte: Animal Pharm Review of 1994 (apud Waack \& Neves, 1994); Animal Pharm Review of 1997

* Não figuravam como representativas ou não tinham sido criadas.

(1) Rhone e Merck se fundiram formando a Merial (2) Comprada pela Pfizer (3) Comprada pela Shering Plough

(4) Fusão da Ciba e Sandoz 
Hoje, o mercado farmacêutico veterinário brasileiro apresenta uma estrutura atomizada, com cerca de 150 empresas atuando neste segmento. Este setor apresenta uma interessante característica de ter nichos abertos às empresas nacionais, decorrente de problemas sanitários e nutricionais idiossincráticos das diversas regiões brasileiras e, também, decorrente de diferentes padrões de distribuição das espécies (Waack et al., 1994).

Liderando, em 1998, como maior empresa de produtos veterinários no Brasil estava a Merial, seguida pela Tortuga com a venda de suplemento alimentar, vide Tabela 11. 
Tabela 11 - As maiores empresas de produtos veterinários no Brasil, 1994 e 1998

\begin{tabular}{|c|c|c|c|c|}
\hline EMPRESA & $\begin{array}{l}\text { FATURAM. } \\
\text { EM 1994 (US\$ } \\
\text { MLHOOESS) }\end{array}$ & $\begin{array}{c}\text { PARTICIP. } \\
\text { NO } \\
\text { MERCADO } \\
\text { EM \% } \\
\end{array}$ & $\begin{array}{c}\text { FATURAM. EM } 1998 \\
\text { (US\$ MILHOEES) - } \\
\text { ACUMULADO } 12 \\
\text { MESES MÓVEIS } \\
\end{array}$ & $\begin{array}{c}\text { PARTICIP. } \\
\text { NO } \\
\text { MERCADO } \\
\text { EM\% } \\
\end{array}$ \\
\hline M.S.D.Agvet & 80.271 & 11,62 & $\begin{array}{l}\text { 109.252 (parceria com a } \\
\text { Rhodia formando a } \\
\text { Merial }{ }^{*} \text { ) }\end{array}$ & $12,7^{*}$ \\
\hline Pfizer & 65.785 & 9,52 & 85.943 & 9,9 \\
\hline Rhodia & 45.254 & 6,55 & $*$ & $*$ \\
\hline $\begin{array}{l}\text { Mallinkrodt } \\
\text { (Pitman) }\end{array}$ & 36.448 & 5,27 & $\begin{array}{c}48.928 \text { (adquiriu a } \\
\text { Coopers) }\end{array}$ & 5,6 \\
\hline $\begin{array}{l}\text { Químio } \\
\text { (Hoechst) }\end{array}$ & 33.858 & 4,90 & 46.292 & 5,3 \\
\hline Bayer & 33.846 & 4,90 & 45.068 & 5,2 \\
\hline Ciba-Geigy & 32.353 & 4,68 & $\begin{array}{l}36.017 \text { (formam com a } \\
\text { Sandoz a Novartis) }\end{array}$ & 4,2 \\
\hline Cyanamid & 27.802 & 4,02 & $\begin{array}{c}61.289 \text { (adquirida pela } \\
\text { Fort Dodge) } \\
\end{array}$ & $7,1^{* *}$ \\
\hline Vallée & 27.409 & 3,97 & 34.002 & 3,9 \\
\hline Solvay & 25.527 & 3,69 & $\begin{array}{c}\text { ** (adquirida pela Fort } \\
\text { Dodge) }\end{array}$ & $* *$ \\
\hline Fatec & 24.151 & 3,50 & 30.335 & 3,5 \\
\hline $\begin{array}{l}\text { Schering } \\
\text { Plough }\end{array}$ & 20.268 & 2,93 & 31.445 & 3,6 \\
\hline Elanco & 17.521 & 2,54 & 33.396 & 3,9 \\
\hline Roche & 13.848 & 2,00 & 24.101 & 2,8 \\
\hline $\begin{array}{l}\text { SmithKline } \\
\text { Beecham }\end{array}$ & 12.455 & 1,80 & Comprada pela Pfizer & $\begin{array}{l}\text { Comprada } \\
\text { pela Pfizer }\end{array}$ \\
\hline Wyeth & 8.900 & 1,29 & & \\
\hline IRFA & 8.195 & 1,19 & 9.110 & 1,1 \\
\hline Biovet & 8.154 & 1,18 & 8.825 & 1,0 \\
\hline \begin{tabular}{|l|} 
Fisons \\
(Pearson)
\end{tabular} & 7.275 & 1,05 & & \\
\hline Virbac & 5.227 & 0,76 & 16.487 & 1,9 \\
\hline Boehringer & 4.954 & 0,72 & 5.359 & 0,6 \\
\hline Agripharm & 4.950 & 0,72 & & \\
\hline Leivas Leite & 4.535 & 0,66 & & \\
\hline Bravet & 4.145 & 0,60 & 5.658 & 0,7 \\
\hline Outros & 34.385 & 4,98 & 233.571 & 27 \\
\hline
\end{tabular}

Fonte: Waack \& Neves, 1995; SINDAM, faturamento de julho de 1998 


\subsubsection{Tendências mundiais}

Nos países desenvolvidos, onde a demanda quantitativa apresenta-se estagnada e a demanda qualitativa está em ascensão, a coordenação das cadeias agroalimentares tornase necessidade urgente. $O$ setor de fármacos veterinários, como está presente em todos os setores de produção animal, terá também que se adaptar às novas exigências. Por exemplo, a garantia de ausência de resíduos nos produtos de origem animal, a preocupação com a menor ingestão de gordura e a concentração de colesterol nos alimentos são fatores direta e indiretamente relacionados com o setor em questão.

Segundo Tejon \& Xavier (1998), a produção rural vem passando por significativo processo de concentração produtiva e aumento da eficiência de produtividade, causando a diminuição do número de agricultores no mundo todo.Dessa forma, um número menor de propriedades, muito bem gerenciadas, altamente produtivas e integradas eficazmente com o sistema que vem depois da porteira concentra a oferta de matéria prima vegetal e animal.

O processo de concentração da produção em unidades rurais provocou um "repensar" do marketing rural, aproximando-o cada vez mais do marketing de relacionamento e da "célula do consumidor" (Tejon \& Xavier, op. cit.). Evidentemente, como citam os autores, uma organização terá limitado seu sucesso e expansão, se não tiver uma visão sistêmica da cadeia consumidora de produtos veterinários.

\subsubsection{Tendências no Brasil}

Segundo Farina \& Zylbersztajn (1998), a economia brasileira passa por transformações estruturais muito importantes e rápidas. Neste momento começa-se a contestar a localização geográfica da produção primária e das plantas industriais, assim como as relações verticais entre segmentos constituintes das cadeias produtivas. A competição deixa de ser de âmbito nacional e adquire dimensões globais, tudo isso em meio a uma evolução tecnológica inusitada.

No Brasil, com a abertura econômica e a redução nas tarifas alfandegárias, torna-se evidente o problema das barreiras sanitárias e a importância de se garantir a qualidade 
dos produtos de origem animal comercializados, tanto no mercado interno como no mercado externo. Nesse contexto, a indústria farmacêutica tem o importante papel de prever tendências, ajustar-se às novas demandas e coordenar o sistema, repassando aos produtores as necessidades do mercado consumidor.

\subsection{Os Canais, Funções e Transações}

O segmento de fármacos veterinários fornece produtos para diversos sistemas agroindustriais, como o do leite, da carne bovina, aves, suínos e outros. Os agentes desse sistema são a indústria química de base, a indústria farmacêutica, os distribuidores, os agentes influenciadores na tomada de decisão e os consumidores. A cadeia industrial de fármacos veterinários pode ser estruturada conforme o Quadro 2 e a Figura 6. 
Quadro 2 - Cadeia agroindustrial do setor farmacêutico veterinário

\begin{tabular}{|c|c|c|c|c|}
\hline $\begin{array}{c}\text { Insumos: } \\
\text { Química de } \\
\text { base } \\
\text { (fornecedor } \\
\text { a de } \\
\text { principios } \\
\text { ativos) } \\
\end{array}$ & $\begin{array}{c}\text { Indústria } \\
\text { farmacêutica } \\
\text { veterinária }\end{array}$ & Distribuiçāo & Varejo & Consumidores \\
\hline $\begin{array}{l}\text { - Basf } \\
\text { - Rhodia } \\
\text { - Hoechst } \\
\text { (Químio) } \\
\text { - Sandoz } \\
\text { - Roche } \\
\text { - Biochimie } \\
\text { - FMC } \\
\text { - Basf } \\
\text { - Outras }\end{array}$ & $\begin{array}{l}\text { - Boehringer } \\
\text { Ingelheim } \\
\text { - Bayer } \\
\text { - Pfizer } \\
\text { - Merial } \\
\text { - Novartis } \\
\text { - Shering Plough } \\
\text { - Vallée } \\
\text { - Químio } \\
\text { - Rhodia } \\
\text { - Hoechst } \\
\text { - American Home } \\
\text { - Vallée } \\
\text { - Outras }\end{array}$ & $\begin{array}{l}\text { - Atacadistas } \\
\text { exclusivos } \\
\text { - Atacadistas } \\
\text { não exclusivos } \\
\text { - Vendedores } \\
\text { próprios } \\
\text { - Vendedores } \\
\text { autônomos }\end{array}$ & $\begin{array}{l}\text { - Atacadistas } \\
\text { (exclusivos e } \\
\text { não } \\
\text { exclusivos) } \\
\text { - Médias Casas } \\
\text { agropecuárias } \\
\text { - Pequenas casas } \\
\text { agropecuária } \\
\text { - Cooperativas } \\
\text { - Veterinários }\end{array}$ & \begin{tabular}{|l} 
- Pequenos \\
produtores \\
agrícolas \\
- Médios \\
produtores \\
agrícolas \\
- Grandes \\
produtores \\
agrícolas \\
- Veterinário \\
- Proprietários \\
de animais de \\
estimação
\end{tabular} \\
\hline
\end{tabular}

- Fonte: Elaborado pelo autor 
Figura 6 - Cadeia Industrial de fármacos veterinários

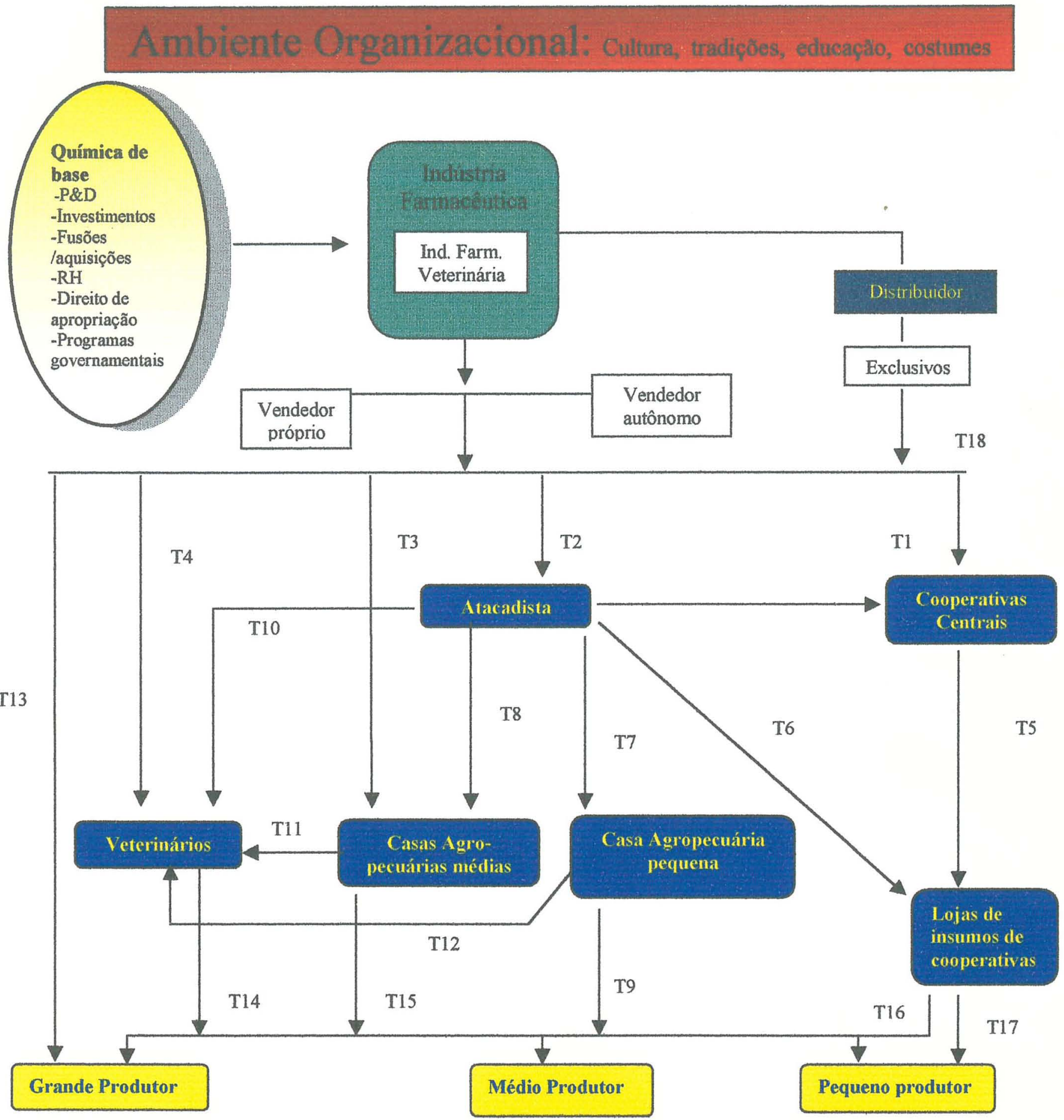


A indústria farmacêutica veterinária pode-se relacionar com o mercado de várias formas, segundo resultados da pesquisa, ilustradas nas Tabelas $12,13,14$ e 15, descritas abaixo:

Tabela 12 - Formas de distribuição predominantes utilizadas pelas empresas por região

\begin{tabular}{l|cccccc}
\hline & $\begin{array}{c}\text { Distribuidor } \\
\text { exclusivo }\end{array}$ & $\begin{array}{c}\text { Vendedor } \\
\text { autônomo }\end{array}$ & $\begin{array}{c}\text { Vendedor } \\
\text { próprio }\end{array}$ & $\begin{array}{c}\text { Venda } \\
\text { direta }\end{array}$ & Atacadista & Revenda \\
\hline Centro Oeste & 0,36 & 0,36 & 0,36 & 0,45 & 0,18 & 0,54 \\
Sudeste & 0,54 & 0,18 & 0,45 & 0,36 & 0,36 & 0,45 \\
Sul & 0,36 & 0,18 & 0,54 & 0,27 & 0,27 & 0,54 \\
Norte & 0,09 & 0,18 & 0,27 & 0,10 & 0,18 & 0,36 \\
Nordeste & 0,18 & 0,36 & 0,36 & 0,09 & 0,27 & 0,45 \\
\hline Brasil & 0,63 & 0,63 & 0,54 & 0,54 & 0,46 & 0,63 \\
\hline
\end{tabular}

Fonte: Elaborado pela autora

Tabela 13 - Faixa de comissão concedida aos vendedores autônomos

\begin{tabular}{l|ccc}
\hline Desconto/Produto & $\mathbf{1 - 5 \%}$ & $\mathbf{6 - 1 0 \%}$ & mais11\% \\
Antiparasitários & 0,17 & 0,83 & 0,00 \\
Antibióticos & 0,14 & 0,72 & 0,14 \\
\hline
\end{tabular}

Fonte: Elaborado pela autora

Tabela 14 - Padrão de concessão de descontos por linha de produto

\begin{tabular}{l|ccc}
\hline & Volume & Linha & Individualizada \\
\hline Antiparasitários & 0,28 & 0,36 & 0,36 \\
Antibióticos & 0,28 & 0,36 & 0,36 \\
\hline
\end{tabular}

Fonte: Elaborado pela autora

Tabela 15 - Padrão de concessão de descontos concedidos por canal de distribuição

\begin{tabular}{l|cccc}
\hline & Menos 5\% & $5-10 \%$ & $11-20 \%$ & mais 20\% \\
\hline Venda direta & 0,33 & 0,67 & 0 & 0 \\
Atacadista & 0 & 0 & 0,33 & 0,67 \\
Distribuidores exclusivos & 0,15 & 0,14 & 0,28 & 0,43 \\
Revenda & 0 & 0,16 & 0,50 & 0,34 \\
\hline
\end{tabular}

Fonte: Elaborado pela autora 
- Distribuidores exclusivos (T18): 63\% das empresas entrevistadas trabalham com este tipo de transação, com predominância no Sudeste. Estima-se que as vendas ocorridas através desse canal correspondam a, aproximadamente, $33 \%$ do total comercializado no setor, representado por 200 grandes distribuidores e atacadistas. A distribuidora tem a função de divulgar e revender o produto para médias e pequenas casas agropecuárias da região. Distribuidoras exclusivas têm cotas de vendas a serem cumpridas, enquanto as não exclusivas, das quais também dependem as empresas para atingirem o consumidor final, representam transações extremamente conflituosas, infiéis e assimétricas. Nos dois casos, cabe às empresas a função de fazer um trabalho de marketing junto ao consumidor, garantindo a geração de demanda.

O desconto máximo fornecido pelas empresas para este tipo de canal é de $30 \%$, sendo que $43 \%$ das empresas adotam política de desconto acima de $20 \%$ (Tabela 15). Segundo Aldebarã (1998), todos os distribuidores têm equipes de vendas externas e, $58,3 \%$ deles oferecem assistência técnica. Os distribuidores atuam com atividades de comunicação, entre as quais observam-se, principalmente, as promoções de vendas $(83,3 \%)$, merchandising (75\%), palestras e dias de campo $(41,7 \%)$, cursos para lojistas, cursos para produtores e telemarketing (33,3\%), mala direta $(25 \%)$ e propaganda $(8,3 \%)$.

- Vendedores autônomos: 63 \% das empresas entrevistadas utilizam esta forma de venda. Neste tipo de relacionamento não há o comprometimento da empresa em custear o vendedor, que se responsabiliza pelo frete e por outros custos.

A comissão varia de acordo com a linha de produto em $83 \%$ dos casos, e a média de comissão é entre $6-10 \%$ sobre as vendas, tanto para antiparasitários como para antibióticos (Tabela 13). Importante observar que 99\% das empresas utilizam só as vendas como base de cálculo para pagamento e $1 \%$ utilizam vendas mais cobrança. Segundo Aldebarã (1998), os produtos que apresentam o maior percentual de comissão são os biológicos com $12,7 \%$, seguidos pela venda direta ao consumidor e vendas para avicultura, suinocultura e eqüinocultura com $10 \%$ de comissão. Em terceiro lugar, estão os terapêuticos e os antibióticos com $6 \%$ de comissão. Por último, 
a vacina de febre aftosa com uma comissão de 1,5\%. Os prêmios foram utilizados, em $54,5 \%$ das empresas, como forma esporádica de incentivo. Em $82 \%$ dos casos, a comissão só é paga após o recebimento do valor da venda, caracterizando-se um tipo de salvaguarda da empresa. $E$, em $100 \%$ dos casos, a empresa não oferece benefícios para os representantes autônomos.

Uma falha desse tipo de transação é a falta de incentivos ao vendedor para vender produtos que tenham baixa participação no mercado e que precisem de esforço maior de sua parte. Com isso, os vendedores acabam se resguardando em produtos de venda constante e garantida e não trabalhando lançamentos e produtos cuja vida já está em declínio.

- Vendedores próprios: $54 \%$ das empresas entrevistadas utilizam-se desta forma de transação com o mercado. Utilizar vendedores da própria é uma forma de salvaguarda para garantir que regiões de interesse sejam cobertas comercialmente e que todos os produtos sejam trabalhados. $\mathrm{Na}$ região Sul predomina este tipo de canal de distribuição. Segundo Aldebarã (1998) a forma de salário varia e, em $50 \%$ dos casos, paga-se um fixo mais prêmios, em $21,4 \%$ das empresas, um fixo mais comissão e, em $28,6 \%$, apenas o fixo. Os vendedores vinculados recebem ajuda de custo e beneficios.

- Venda direta ao produtor (T13): essa forma de comercialização é estimada em $22 \%$ do total comercializado pelas indústrias. Das empresas entrevistadas $54 \%$ realizam a venda direta, principalmente para pecuaristas de corte na região Centro-Oeste. Esse tipo de relacionamento da empresa com o produtor é dificultado pela ampla extensão territorial brasileira e pela presença de diferentes nichos consumidores. Outro fator limitante desse tipo de transação direta é a possibilidade de conflito com as casas agropecuárias e atacadistas que têm o interesse de intermediar a relação entre a indústria e o consumidor. Quando se sentem lesadas, esses estabelecimentos comerciais boicotam as empresas não adquirindo mais seus produtos, o que as impede de ganhar com venda aos pequenos produtores. Das empresas entrevistadas que utilizam este canal de distribuição, $67 \%$ fornecem entre 5 a $10 \%$ de desconto. 
- Venda a atacadistas (T2): juntamente com os distribuidores, estima-se que são responsáveis por $33 \%$ das vendas de produtos veterinários. Das empresas entrevistadas $46 \%$ responderam utilizá-los como canal de distribuição, principalmente na região Sudeste. Esse tipo de transação não garante exclusividade de um produto ou de uma empresa e o relacionamento pode ser classificado como via mercado, ou seja, não há compromissos formais. Tanto a empresa como os atacadistas são infiéis, pois as vantagens oferecidas por uma empresa fazem com que o balconista influa na tomada de decisão do comprador, levando-o a adquirir um produto que beneficie o balconista. Por outro lado, as empresas, às vezes, "atropelam" o atacadista realizando vendas diretas na sua região, o que gera disputas e desavenças. Segundo resultados da pesquisa $67 \%$ das empresas fornecem descontos para este canal acima de $20 \%$ e, segundo Aldebarã (1998), o desconto fornecido para este setor é, em média, de 20-25\%.

- Venda a casas agropecuárias/ Revenda (T3, T7, T8): no Brasil, calcula-se que haja 22.000 revendas. Estima-se que a venda direta à revenda corresponde a apenas $12 \%$ do total comercializado no mercado, mas $63 \%$ das empresas utilizam este canal como forma de distribuição de seus produtos. Das empresas entrevistadas, 50\% praticam descontos entre 11 e $20 \%$ e $34 \%$ das empresas oferecem superiores a $20 \%$. Algumas casas agropecuárias especializadas se destacam nesse tipo de relação por apresentarem vendas técnicas e especializadas, porém o segmento que melhor representa esse tipo de transação é o de eqüinos.

- Venda direta a cooperativas (T1), que por sua vez repassam via loja de insumos (T5) aos produtores cooperados. Estima-se que as vendas diretas às cooperativas correspondam a $20 \%$ da vendas totais realizadas no mercado de animais de produção. No Brasil, há aproximadamente 1.500 cooperativas, cujas lojas de insumos, quando pertencentes a pequenas e médias cooperativas, podem adquirir os produtos de atacadistas (T6). $\mathrm{O}$ relacionamento entre indústria e cooperativa caracteriza-se pelo 
grau de predominância de características de transação via mercado, em que não há fidelidade de compra.

- Venda direta ao veterinário (T4): há três tipos de atuação de veterinários intermediando a relação entre indústria e consumidor. Há aqueles que cobram o serviço e incluem o produto, os que cobram o serviço e prescrevem o produto e aqueles que vendem o produto e não cobram o serviço. Não há dados sobre a participação de cada um na decisão de compra ou na participação de compras de produtos das empresas. 


\section{RESULTADOS DA PESQUISA DE CAMPO SOBRE PERCEPÇÂO}

Os resultados da pesquisa de campo sobre a percepção da demanda serão apresentadas em duas partes. A primeira parte apresenta a percepção da demanda das onze empresas farmacêuticas veterinárias entrevistadas, previamente citadas.

A segunda parte apresenta a percepção que o canal de distribuição tem do mercado consumidor. Foram enviados 339 questionários para distribuidores, atacadistas, revendas e revendas de cooperativas. Destes 127 foram para o Sudeste, 87 para o Sul, 99 para o Centro-Oeste, 23 para o Nordeste e 3 para o Norte. Retornaram respondidos 80 questionários, como pode ser observado no quadro de resultados obtidos (Quadro 3).

Quadro 3 - Resultados dos questionários

\begin{tabular}{|l|c|c|c|c|c|c|}
\hline & Sudeste & Sul & $\begin{array}{c}\text { Centro } \\
\text { Oeste }\end{array}$ & Nordeste & Norte & Total \\
\hline Total de questionário enviado & 127 & 87 & 99 & 23 & 3 & 339 \\
\hline Total de questionários respondidos & $\begin{array}{c}25 \\
(19 \%)\end{array}$ & $\begin{array}{c}24 \\
(27 \%)\end{array}$ & $\begin{array}{c}25 \\
(25 \%)\end{array}$ & $\begin{array}{c}6 \\
(26 \%)\end{array}$ & $\begin{array}{c}(0 \%) \\
(23 \%)\end{array}$ \\
\hline $\begin{array}{l}\text { Número de revenda agropecuária } \\
\text { que responderam na amostra }\end{array}$ & $40 \%$ & $63 \%$ & $64 \%$ & $67 \%$ & $0 \%$ & $56 \%$ \\
\hline $\begin{array}{l}\text { Número de Atacadista /Distribuidor } \\
\text { que responderam na amostra }\end{array}$ & $24 \%$ & $4 \%$ & $24 \%$ & $33 \%$ & $0 \%$ & $19 \%$ \\
\hline $\begin{array}{l}\text { Número de revenda de cooperativa } \\
\text { que responderam na amostra }\end{array}$ & $36 \%$ & $33 \%$ & $12 \%$ & $0 \%$ & $0 \%$ & $25 \%$ \\
\hline
\end{tabular}

Fonte: Resultado da pesquisa

\subsection{Percepção da demanda das empresas}

O mercado de fármacos veterinários apresenta, em relação à percepção da demanda, duas categorias distintas de produtos consumidos: 
1. Genéricos: produtos de uso comum, sem grandes barreiras à entrada, não protegidos por patentes.

2. Especialidades: produtos protegidos por patentes e marcas.

Essas duas classes de produtos diferem quanto ao preço, público alvo, efetividade e por estarem ou não protegidos por lei de patente.

As empresas precisam do canal de distribuição para satisfazer a demanda, o que ocasiona uma dependência unilateral que, variando com o tipo de produto que possuem (genérico ou especialidade), pode ser minimizada ou maximizada (Tabela 16). 
Tabela 16 - Comparação das variáveis de marketing entre produtos genéricos e especialidades

\begin{tabular}{|c|c|c|}
\hline & Genérico & Especialidades \\
\hline $\begin{array}{l}\text { Mercado } \\
\text { alvo }\end{array}$ & $\begin{array}{l}\text { Consumidores cuja elasticidade } \\
\text { preço da demanda é alta. Ou seja, } \\
\text { pequenas variações no preço } \\
\text { levam o consumidor a procurar } \\
\text { por um substituto mais acessível. } \\
\text { Apresentam fidelidade à marca } \\
\text { variável, grande facilidade de } \\
\text { troca terapêutica dependendo da } \\
\text { boa administração da empresa na } \\
\text { comunicação. Possivelmente, o } \\
\text { balconista da revenda tenha forte } \\
\text { influência sobre este indivíduo }\end{array}$ & $\begin{array}{l}\text { Consumidores cuja elasticidade preço da } \\
\text { demanda é baixa. Geralmente são fiéis à } \\
\text { marca e apresentam uma margem de } \\
\text { aceitabilidade da variação do preço } \\
\text { maior. Nesta categoria estão presentes } \\
\text { os que buscam inovação e nova } \\
\text { tecnologia }\end{array}$ \\
\hline $\begin{array}{l}\text { Canal de } \\
\text { distribuição }\end{array}$ & $\begin{array}{l}\text { Comunicação mais dinâmica, os } \\
\text { compradores são dispersos, o } \\
\text { poder de barganha da empresa é } \\
\text { limitado, as barreiras de entrada } \\
\text { a novos produtos é baixa e os } \\
\text { principais fatores de concorrência } \\
\text { são preço e promoção. } \\
\text { Compete basicamente via preço } \\
\text { (análise dos concorrentes) e } \\
\text { ponto de venda (presença efetiva, } \\
\text { geralmente acompanhada de um } \\
\text { portfólio de suporte, garantindo } \\
\text { demanda ) }\end{array}$ & $\begin{array}{l}\text { Problemas de comunicação. Necessita de } \\
\text { canais de comunicação alternativos para } \\
\text { atingir o consumidor final. Estas formas } \\
\text { de comunicação são representadas por } \\
\text { amostras, dias de campo, veterinários } \\
\text { próprios provendo suporte técnico as } \\
\text { unidades produtivas. } \\
\text { Competem basicamente com o produto, } \\
\text { a marca associada à ele a garantia de } \\
\text { sua eficácia. Os produtos que se lançam } \\
\text { primeiro no mercado atendendo a nichos } \\
\text { específicos possuem grandes } \\
\text { oportunidades de obterem fidelidade à } \\
\text { marca }\end{array}$ \\
\hline
\end{tabular}

Fonte: elaborado pela autora a partir das entrevistas

Os genéricos, geralmente, são considerados commodities, com vendas em alta escala a preço competitivo. Apresentam baixo conflito com os canais de distribuição, diferentemente dos produtos denominados especialidades, pois estes geralmente necessitam de um treinamento para a sua correta utilização.

No Brasil, as empresas farmacêuticas veterinárias apresentam uma parcial dependência do canal de distribuição para obterem as características da demanda do consumidor final. Essa dependência pode ser explicada pelo fato de o país apresentar 
características demográficas, geográficas e comportamentais peculiares a cada região. Logo, as empresas não são capazes de atingir todos os consumidores, em diferentes lugares, de forma eficiente precisando dos canais de distribuição para maximizarem suas ativiadades.

Nos Estados Unidos da América, o maior mercado consumidor de produtos veterinários, a forma de criação animal é tanto extensiva como intensiva. Nesta última, as vendas de especialidades ganham forte representatividade, pois a criação confinada propicia o aparecimento de resistência rápida a princípios ativos, rápida disseminação de doenças, prejuízos irrecuperáveis a curto e médio prazo, exigindo rígido controle das doenças e o uso de produtos de alta eficácia. Nestes casos, as vendas diretas ao consumidor são favorecidas em detrimento aos canais de distribuição. Como no Brasil as condições climáticas favorecem o pastoreio anual e o baixo custo-oportunidade de certas regiões favorecem a pecuária de extrativismo, a realidade norte americana demorará alguns anos para chegar ao Brasil. Certamente, as exigências crescentes de rastreabilidade impostas por países desenvolvidos à carne importada, estarão obrigando mais pecuaristas a se especializar.

Para melhor caracterizar o intermediário das relações deste setor, os próximos capítulos descrevem como estão estruturados os canais de distribuição, segundo a perspectiva das empresas farmacêuticas veterinárias.

\subsubsection{Canal de distribuição}

Segundo os resultados obtidos pelos questionários junto às empresas, as formas de distribuição utilizadas por categoria de produto variam por espécie animal, como se pode visualizar na Tabela 17. 
Tabela 17 - Percentagem de empresas entrevistadas que disseram trabalhar com as diferentes formas de distribuição

\begin{tabular}{l|lcccccc}
\hline \multicolumn{2}{c}{} & \multicolumn{3}{c}{$\begin{array}{c}\text { Distribuidor Autônomo } \\
\text { exclusivo }\end{array}$} & $\begin{array}{c}\text { Venda } \\
\text { direta }\end{array}$ & Atacadista Revenda \\
\hline Antiparasitários & Bovinos de leite & $60 \%$ & $10 \%$ & $20 \%$ & $48 \%$ & $60 \%$ \\
\cline { 2 - 7 } & Eqüinos & $75 \%$ & $13 \%$ & $0 \%$ & $25 \%$ & $50 \%$ \\
\hline Antibióticos & Bovinos de leite & $90 \%$ & $18 \%$ & $18 \%$ & $54 \%$ & $54 \%$ \\
\cline { 2 - 7 } & Eqüinos & $77 \%$ & $22 \%$ & $11 \%$ & $44 \%$ & $66 \%$ \\
& & & & & & & \\
\end{tabular}

Fonte: Resultado da pesquisa

$\mathrm{Na}$ venda de antiparasitários e antibióticos, a forma de distribuição predominante varia entre as categorias animais. Müller - Hagedorn, citado por Waack (1999), questiona o que determina a escolha de uma empresa por um sistema de distribuição dentro de um contínuo espectro de opções. $O$ autor tem por hipótese que, se um canal de distribuição não participa dos custos de produção, então $100 \%$ dos custos de distribuição a eles associados podem ser considerados custos de transação que podem ser reduzidos. Determinam a escolha de um sistema de distribuição questões como quantidade demandada pelo canal de distribuição, custos de se trabalhar com o canal, preferências de demanda e homogeneidade dos mercados, incerteza na provisão de demandas, elasticidade da publicidade, assimetria das capacidades gerenciais entre produtores e distribuidores, vantagens monopolísticas de distribuidores especializados além da competência no uso de informações de mercado.

Os resultados obtidos pelos questionários junto às empresas entrevistadas demonstraram que, na pecuária de leite, $60 \%$ e $90 \%$ das empresas utilizam distribuidores exclusivos como rotas de comercialização na venda de antiparasitários e antibióticos, respectivamente (Tabela 17). As revendas também foram citadas por $60 \%$ das empresas entrevistas, como um dos canais utilizados na venda de antiparasitários.

Analisando estas rotas de comercializações pela capacidade de agregação de valor de cada agente proposto por Waack (1999), a rota de comercialização predominante na 
pecuária de leite condiz com uma atividade de contrastes: altamente tecnificada e de extrativismo, ao mesmo tempo (Tabela 18). O rebanho brasileiro situa-se em torno de 20 milhões de animais adultos, dos quais mais da metade do leite produzido provêm de pequenas propriedades rurais com baixa produtividade, quase sempre informal. Logo, a produção não tecnificada ainda é predominante no território brasileiro, justificando a presença das revendas como importantes formas de distribuição para antiparasitários. Por um lado, há "ilhas de excelência leiteira" que necessitam de um serviço de vendas mais especializado, justificando a importância dos distribuidores exclusivos.

Tabela 18 - Capacidade de agregação de valor das empresas distribuidoras de insumos veterinários

\begin{tabular}{|l|c|c|c|}
\hline & $\begin{array}{c}\text { Capacidade de } \\
\text { contribuir para } \\
\text { decisão técnica } \\
\text { do cliente }\end{array}$ & $\begin{array}{c}\text { Capacidade de } \\
\text { influenciar a } \\
\text { decisão comercial } \\
\text { do cliente }\end{array}$ & $\begin{array}{c}\text { Capacidade de } \\
\text { agregar } \\
\text { serviços ao } \\
\text { cliente }\end{array}$ \\
\hline Distribuidor especializado & Alta & Alta & Alta \\
\hline Distribuidor exclusivo ou não & Baixa & Alta & Média \\
\hline Atacadista & Baixa & Alta & Baixa \\
\hline Revenda & Baixa para média & Alta & Baixa \\
\hline Revenda de cooperativas & Média & Alta & Média \\
\hline Vendedor autônomo & Baixa & Alta & Baixa \\
\hline Vendedor próprio & Alta & Média & Alta \\
\hline
\end{tabular}

Fonte: Waack, R. (1999)

$\mathrm{Na}$ eqüinocultura, 75\% das empresas trabalham com distribuidores exclusivos para a venda de antiparasitários. E $77 \%$ delas responderam utilizar desta mesma rota para a comercialização de antibióticos. De acordo com as empresas, nesse setor, a venda através dos distribuidores exclusivos é a principal rota de comercialização de antiparasitários e antibióticos. Esse fato pode ser explicado por serem os animais de corrida o segmento líder de compra, pois, representando $3 \%$ da população eqüestre brasileira, consomem $50 \%$ das vendas de medicamentos. Esse segmento exige maior capacidade técnica de venda, justificando a forma de comercialização vigente. 


\subsubsection{Formas de distribuição nas diferentes regiões}

A importância conferida às diferentes formas de distribuição não são constantes nas diversas regiões. Por exemplo, no Centro-Oeste 54\% das empresas entrevistadas consideram as revendas como importante forma de distribuição regional para antiparasitários, seguida pela venda direta. No Sudeste, as principais rotas de comercialização citadas foram distribuidores exclusivos, vendedores próprios e revendas.

No Sul, por sua vez, predominaram revendas, incluindo revendas de cooperativas, e vendedores próprios (Tabela 19 e Tabela 20 ).

Tabela 19 - Freqüência com que as formas de distribuição foram citadas como importantes pelas empresas nas diversas regiões para antiparasitários

\begin{tabular}{lccccc}
\hline & Centro Oeste & Sudeste & Sul & Nordeste & Norte \\
\hline Distribuidor exclusivo & $36 \%$ & $54 \%$ & $36 \%$ & $9 \%$ & $18 \%$ \\
Vendedor autônomo & $36 \%$ & $18 \%$ & $18 \%$ & $18 \%$ & $36 \%$ \\
Vendedor próprio & $36 \%$ & $45 \%$ & $54 \%$ & $27 \%$ & $36 \%$ \\
Venda direta & $45 \%$ & $36 \%$ & $27 \%$ & $9 \%$ & $9 \%$ \\
Atacadista & $18 \%$ & $36 \%$ & $27 \%$ & $18 \%$ & $27 \%$ \\
Revenda & $54 \%$ & $45 \%$ & $54 \%$ & $36 \%$ & $45 \%$ \\
\hline
\end{tabular}

Fonte: Resultado da pesquisa

Tabela 20 - Freqüência com que as formas de distribuição foram citadas como importantes pelas empresas nas diversas regiões para antibióticos

\begin{tabular}{lccccc}
\hline & Centro Oeste & Sudeste & Sul & Nordeste & Norte \\
\hline Distribuidor exclusivo & $45 \%$ & $63 \%$ & $45 \%$ & $18 \%$ & $27 \%$ \\
Vendedor autônomo & $45 \%$ & $36 \%$ & $27 \%$ & $27 \%$ & $45 \%$ \\
Vendedor próprio & $36 \%$ & $45 \%$ & $54 \%$ & $27 \%$ & $36 \%$ \\
Venda direta & $45 \%$ & $36 \%$ & $27 \%$ & $9 \%$ & $9 \%$ \\
Atacadista & $18 \%$ & $36 \%$ & $27 \%$ & $18 \%$ & $27 \%$ \\
Revenda & $54 \%$ & $45 \%$ & $54 \%$ & $36 \%$ & $45 \%$ \\
\hline
\end{tabular}

Fonte: Resultado da pesquisa

Neves (1999) atribui ao setor de distribuição crescente importância, agente capaz de identificar mais facilmente as tendências de consumo e coordenação do fluxo de informação e mercadoria. Os canais de distribuição formam um composto mercadológico 
capaz de oferecer vantagem competitiva sustentável, embora seu custo represente uma parcela considerável do preço final do produto vendido ao consumidor. Como se nota na distribuição das formas de canais adotados por região as revendas são mais observadas no Centro-Oeste, enquanto revendas e vendedores autônomos encontram-se no Sul e distribuidores exclusivos na região sudeste.

Uma das tendências previstas é uma reestruturação da comercialização com o aumento das vendas diretas ao consumidor, visando aproximar o produtor, usuário final, do agente técnico dentro do conceito de qualidade total de agregação de serviços e cliente preferencial.

\subsubsection{Vendedores}

As empresas contratam para divulgação e vendas de seus produtos vendedores próprios ou autônomos. Ambos apresentam vantagens e desvantagens, que cada empresa deve levar em conta considerando o portfólio que possui e quais os objetivos da empresa para cada região (Tabela 21). 
Tabela 21 - Comparação entre vendedores autônomos e vendedores próprios

\begin{tabular}{|c|c|c|}
\hline & Vendedores autônomos & Vendedores próprios \\
\hline \begin{tabular}{l|l} 
Compromisso \\
com \\
empresa
\end{tabular} & $\begin{array}{l}\text { Não têm compromisso fixo com a } \\
\text { empresa, pois, apenas parte de seus } \\
\text { rendimentos vem da empresa. Não } \\
\text { estão envolvidos com os objetivos da } \\
\text { empresa, por questões trabalhistas. }\end{array}$ & $\begin{array}{l}\text { Têm compromisso com a empresa, } \\
\text { sendo ela, sua única fonte de renda }\end{array}$ \\
\hline Riscos & $\begin{array}{l}\text { Como não há um compromisso formal, } \\
\text { a empresa tem a necessidade de se } \\
\text { salvaguardar para poder lidar com eles, } \\
\text { aumentando os custos de } \\
\text { relacionamento }\end{array}$ & $\begin{array}{l}\text { Apresentam riscos de processos } \\
\text { trabalhistas, custos de impostos e } \\
\text { pagamento de beneficios, } \\
\text { tornando-os mais caros que os } \\
\text { autônomos }\end{array}$ \\
\hline Metas & $\begin{array}{l}\text { Dificuldade de gerar metas, pois os } \\
\text { autônomos por questôes trabalhistas } \\
\text { não fazem parte da discussão do plano } \\
\text { de metas }\end{array}$ & $\begin{array}{l}\text { A meta pode ser rígida, fixada pela } \\
\text { diretoria, gerando conflitos com a } \\
\text { força de vendas, que alegam } \\
\text { imposição de uma meta irreal e } \\
\text { falta de conhecimento do } \\
\text { marketing quanto à realidade do } \\
\text { campo. A meta pode também ser } \\
\text { elaborada em conjunto entre a } \\
\text { força de vendas, departamento de } \\
\text { marketing e diretoria }\end{array}$ \\
\hline Custos fixos & \begin{tabular}{|l|} 
Menores custos fixos. Em situações de \\
recessão, compensa utilizá-los.
\end{tabular} & Altos custos fixos \\
\hline $\begin{array}{l}\text { Relação com } \\
\text { o mercado }\end{array}$ & $\begin{array}{l}\text { Profissional com relações mais livres } \\
\text { com o mercado, sendo geralmente mais } \\
\text { versátil nas vendas }\end{array}$ & Profissionais presos a burocracias \\
\hline Venda técnica & $\begin{array}{|lllr|}\text { Problemas } & \text { com } & \text { motivação } & \text { para } \\
\text { aprender, } & \text { têm } & \text { dificuldade } & \text { de } \\
\text { intermediar } & \text { a relação empresa } & - \\
\text { consumidor } & \text { em áreas de } & \text { vendas } \\
\text { técnicas, } & \text { principalmente } & \text { as } \\
\text { especialidades. São mais utilizados } \\
\text { para venda de produtos genéricos, na } \\
\text { qual a política se baseia em preço e e } \\
\text { volume }\end{array}$ & $\begin{array}{l}\text { São treinados tecnicamente. } \\
\text { Recentemente as empresas estão } \\
\text { contratando mais profissionais } \\
\text { técnicos com capacidade de } \\
\text { solucionar tanto problemas de } \\
\text { vendas como administrativos. } \\
\end{array}$ \\
\hline $\begin{array}{l}\text { Repasse da } \\
\text { Informação }\end{array}$ & $\begin{array}{l}\text { Geralmente representam uma barreira } \\
\text { entre a empresa e o cliente, pois detêm } \\
\text { a informação e não a repassam. Há } \\
\text { assimetria de informação }\end{array}$ & $\begin{array}{l}\text { A comunicação com a empresa é } \\
\text { mais facilitada, porém há ainda } \\
\text { muitos conflitos de comunicação }\end{array}$ \\
\hline
\end{tabular}

Fonte: Entrevistas junto às empresas 


\subsubsection{Vendas por categoria animal nas diferentes regiões}

Em entrevistas com as onze empresas, todas concordaram que a região Sudeste é o principal mercado consumidor para antiparasitários na bovinocultura de leite $\mathrm{e}$ eqüinocultura (Tabela 22).

Tabela 22 - Distribuição da frequiência da importância das regiões como representativas nas vendas de antiparasitários pelas empresas

\begin{tabular}{lccc|ccc}
\hline & \multicolumn{3}{c|}{ Bovino Leite } & \multicolumn{3}{c}{ Eqüinos } \\
\hline & $1^{\circ}$ Lugar & $2^{\circ}$ & $3^{\circ}$ & $1^{\circ}$ Lugar & $2^{\circ}$ & $3^{\circ}$ \\
\hline Centro-Oeste & -- & $36 \%$ & $71 \%$ & --- & $17 \%$ & $100 \%$ \\
Sudeste & $100 \%$ & --- & -- & $87 \%$ & -- & -- \\
Sul & -- & $64 \%$ & $29 \%$ & $12 \%$ & $83 \%$ & -- \\
Norte & -- & --- & -- & -- & -- & -- \\
Nordeste & -- & -- & -- & -- & -- & -- \\
\hline Total & $100 \%$ & $100 \%$ & $100 \%$ & $100 \%$ & $100 \%$ & $100 \%$ \\
\hline
\end{tabular}

Fonte: Resultados da pesquisa

De forma semelhante, nas venda de antibiótico, $91 \%$ e $100 \%$ da empresas responderam que a região Sudeste corresponde à principal região nas vendas para a pecuária de leite e eqüinocultura, respectivamente (Tabela 23).

Tabela 23 - Distribuição da freqüência da importância das regiões como representativas nas vendas de antibióticos pelas empresas

\begin{tabular}{lccc|ccc}
\hline & \multicolumn{3}{c|}{ Bovino Leite } & \multicolumn{3}{c}{ Eqüinos } \\
\hline & $1^{\circ}$ Lugar & $2^{\circ}$ & $3^{\circ}$ & $1^{\circ}$ Lugar & $2^{\circ}$ & $3^{\circ}$ \\
\hline Centro-Oeste & --- & $17 \%$ & $80 \%$ & -- & $10 \%$ & $100 \%$ \\
Sudeste & $91 \%$ & $8 \%$ & -- & $100 \%$ & -- & --- \\
Sul & $9 \%$ & $75 \%$ & $10 \%$ & -- & $90 \%$ & --- \\
Nordeste & --- & -- & $10 \%$ & -- & -- & --- \\
\hline Total & $100 \%$ & $100 \%$ & $100 \%$ & $100 \%$ & $100 \%$ & $100 \%$ \\
\hline
\end{tabular}

Fonte: Resultado da pesquisa 


\subsubsection{Agentes}

As empresas, buscando contornar o problema de ter que obter dados da demanda através dos canais de distribuição, buscam identificar os chamados "influenciadores da demanda" para cada segmento, aqueles que têm, teoricamente, a capacidade de influir/alterar/determinar o consumo de um certo medicamento.

Segundo a visão das empresas, o balconista é o principal agente que influencia na decisão da compra de antiparasitários para bovinocultura de leite (Tabela 24), ao passo que, para antibióticos, quem determina qual medicamento deve ser comprado é o veterinário. Essa diferença de "influenciador" por categoria de produto pode decorrer da especificidade de atuação de cada um e da gravidade do uso incorreto, em caso de falha da identificação da doença a ser tratada.

Tabela 24 - Distribuição da freqüência com que os agentes foram citados como importantes "influenciadores da demanda" na bovinocultura de leite pelas empresas

\begin{tabular}{llccc}
\hline & & $1^{\circ}$ lugar & $2^{\circ}$ lugar & $3^{\circ}$ lugar \\
\hline & Veterinário & $33 \%$ & $11 \%$ & $34 \%$ \\
Antiparasitários & Empregado/peão & - & $11 \%$ & $11 \%$ \\
& Formadores de opinião & $11 \%$ & $11 \%$ & $11 \%$ \\
& Balconista & $45 \%$ & $45 \%$ & -- \\
& Vizinho & -- & -- & $22 \%$ \\
& Proprietário & $11 \%$ & $22 \%$ & $22 \%$ \\
\cline { 2 - 5 } Antibióticos & Total & $100 \%$ & $100 \%$ & $100 \%$ \\
\hline & Veterinário & $64 \%$ & $18 \%$ & $18 \%$ \\
& Empregado/peão & -- & -- & $18 \%$ \\
& Formadores de opinião & $9 \%$ & $28 \%$ & $28 \%$ \\
& Balconista & $18 \%$ & $45 \%$ & $18 \%$ \\
& Vizinho & -- & -- & -- \\
& Proprietário & $9 \%$ & $9 \%$ & $18 \%$ \\
\cline { 2 - 5 } & Total & $100 \%$ & $100 \%$ & $100 \%$ \\
\hline
\end{tabular}

Fonte: Resultado da pesquisa

$\mathrm{Na}$ eqüinocultura, $60 \%$ e $83 \%$ das empresas que produzem e comercializam antiparasitários e antibióticos, respectivamente, consideram o veterinário como o principal "influenciador da demanda" (Tabela 25). Esse fato poderia ser explicado por se 
esta espécie animal uma das mais sensíveis a alterações fisiológicas; logo, um erro de indicação pode ser fatal. Além disso, como as categorias de função equiestre que mais consomem produtos veterinários são a de corrida e a de hipismo, que têm assistência constante de veterinários, reforça-se a explicação de serem eles o principal "influenciador da demanda".

Tabela 25 - Distribuição da freqüência com que os agentes foram citados pelas empresas como os mais importantes "influenciadores da demanda" na eqüinocultura

\begin{tabular}{llccc}
\hline & & $1^{\circ}$ lugar & $2^{\circ}$ lugar & $3^{\circ}$ lugar \\
\hline Antiparasitários & Veterinário & $60 \%$ & - & $20 \%$ \\
& Empregado/peão & -- & -- & $20 \%$ \\
& Formadores de opinião & $20 \%$ & $20 \%$ & $20 \%$ \\
& Balconista & $20 \%$ & $40 \%$ & $40 \%$ \\
& Vizinho & -- & -- & -- \\
& Proprietário & -- & $40 \%$ & -- \\
\hline & Total & $100 \%$ & $100 \%$ & $100 \%$ \\
\hline Antibióticos & Veterinário & $83 \%$ & -- & $17 \%$ \\
& Empregado/peão & -- & $33 \%$ & $17 \%$ \\
& Formadores de opinião & $17 \%$ & -- & $32 \%$ \\
& Balconista & -- & $50 \%$ & $17 \%$ \\
& Vizinho & -- & -- & -- \\
& Proprietário & -- & $17 \%$ & $17 \%$ \\
\cline { 2 - 5 } & Total & $100 \%$ & $100 \%$ & $100 \%$ \\
\hline
\end{tabular}

Fonte: Resultado da pesquisa

\subsubsection{Características de compra dos agentes}

Ainda em relação à percepção da demanda pelas empresas, constatou-se que, quando questionadas quanto aos atributos relevantes para a decisão de compra do produtor, a qualidade e o preço são considerados determinantes para a escolha dos antiparasitários na bovinocultura de leite (Tabela 26). Para antibióticos, no entanto, 54\% das empresas consideram a qualidade como fator decisório de compra. 
Tabela 26 - Distribuição da freqüência dos atributos considerados importantes, em ordem de preferência, na decisão de compra na bovinocultura de leite, sob a perspectiva das empresas

\begin{tabular}{|c|c|c|c|c|c|}
\hline & & $1^{\circ}$ Lugar & $2^{\circ}$ Lugar & $3^{\circ}$ Lugar & $4^{\circ}$ Lugar \\
\hline & Qualidade & $44 \%$ & $44 \%$ & $12 \%$ & -- \\
\hline & Inovação tecnológica & - & $12 \%$ & $22 \%$ & $22 \%$ \\
\hline & Preço & $44 \%$ & $44 \%$ & -- & - \\
\hline \multirow[t]{7}{*}{ Antiparasitários } & Serviço pós-venda & -- & -- & -- & $22 \%$ \\
\hline & Facilidade de aplicação & -- & - & $44 \%$ & $44 \%$ \\
\hline & Design da embalagem & -- & -- & -- & -- \\
\hline & Período de carência & $12 \%$ & -- & $22 \%$ & -- \\
\hline & Tempo de latência & -- & -- & -- & $12 \%$ \\
\hline & Outros & -- & -- & - & -- \\
\hline & Total & $100 \%$ & $100 \%$ & $100 \%$ & $100 \%$ \\
\hline \multirow[t]{10}{*}{ Antibióticos } & Qualidade & $54 \%$ & $27 \%$ & $18 \%$ & -- \\
\hline & Inovação tecnológica & -- & -- & $18 \%$ & $10 \%$ \\
\hline & Preço & $36 \%$ & $63 \%$ & -- & - \\
\hline & Serviço pós-venda & -- & -- & $10 \%$ & $18 \%$ \\
\hline & Facilidade de aplicação & -- & $10 \%$ & $36 \%$ & $36 \%$ \\
\hline & Design da embalagem & -- & -- & -- & -- \\
\hline & Período de carência & $10 \%$ & -- & $18 \%$ & $18 \%$ \\
\hline & Tempo de latência & -- & -- & -- & $18 \%$ \\
\hline & Outros & -- & -- & - & -- \\
\hline & Total & $100 \%$ & $100 \%$ & $100 \%$ & $100 \%$ \\
\hline
\end{tabular}

Fonte: Resultado da pesquisa

Para a eqüinocultura, a qualidade é o fator decisivo na escolha dos dois tipos produtos questionados, sobretudo na compra de antibióticos. O preço vem em segundo lugar como o fator mais importante (Tabela 27). 
Tabela 27 - Distribuição da freqüência com que os atributos foram citados como importantes, em ordem de preferência, na decisão de compra na eqüinocultura, sob a perspectiva das empresas

\begin{tabular}{llcccc}
\hline & & $1^{\circ}$ Lugar & $2^{\circ}$ Lugar & $3^{\circ}$ Lugar & $4^{\circ}$ Lugar \\
\hline & Qualidade & $50 \%$ & $30 \%$ & $10 \%$ & - \\
& Inovação tecnológica & $25 \%$ & $10 \%$ & $30 \%$ & - \\
Antiparasitários & Preço & $12,5 \%$ & $40 \%$ & $30 \%$ & - \\
& Serviço pós-venda & -- & $10 \%$ & -- & $25 \%$ \\
& Facilidade de aplicação & -- & $10 \%$ & $20 \%$ & $37,5 \%$ \\
& Design da embalagem & -- & -- & $10 \%$ & - \\
& Tempo de latência & $12,5 \%$ & -- & -- & $37,5 \%$ \\
& Outros & -- & -- & -- & -- \\
\cline { 2 - 6 } Antibióticon & Total & $700 \%$ & $100 \%$ & $100 \%$ & $100 \%$ \\
\hline & Qualidade & $11 \%$ & $22 \%$ & $33 \%$ & -- \\
& Inovação tecnológica & -- & $45 \%$ & $45 \%$ & -- \\
& Preço & -- & -- & $11 \%$ & $27 \%$ \\
& Serviço pós-venda & -- & $11 \%$ & $11 \%$ & $45 \%$ \\
& Facilidade de aplicação & -- & - & -- & $14 \%$ \\
& Design da embalagem & $11 \%$ & $11 \%$ & -- & $14 \%$ \\
& Tempo de latência & & & & \\
\hline & Outros & $100 \%$ & $100 \%$ & $100 \%$ & $100 \%$ \\
\hline
\end{tabular}

Fonte: Resultado da pesquisa

O padrão de concorrência percebido pelas empresas difere da bovinocultura para a eqüinocultura. Para antiparasitários na bovinocultura o preço e qualidade são fatores determinantes de compra, enquanto na eqüinocultura, somente o fator qualidade mostrase essencial na aquisição de antiparasitários e de antibióticos. Essa diferença poderia ser explicada pelo fato de que, aos olhos do pecuarista de leite, a maioria dos antiparasitários se apresentam homogêneos e, assim, a competição se volta para o preço. Na criação de eqüinos, o padrão de concorrência vigente é mais voltado para qualidade. 


\subsection{Percepção da demanda pelo canal de distribuição}

Segundo a percepção dos canais de distribuição, a principal faixa etária dos consumidores que vão ao ponto de venda situa-se entre 30-45 anos (Tabela 28). De modo semelhante, a pesquisa realizada pela Associação Brasileira de Marketing Rural - ABMR (1998/1999), informa que 53\% dos produtores rurais têm entre 30 e 50 anos de idade. $O$ perfil do produtor levantado demonstra que mais da metade dos consumidores desenvolvem tanto atividades agropecuárias como agrícola. Segundo os resultados da ABMR, $17 \%$ são analfabetos ou têm primário incompleto, $38 \%$ têm o primário completo ou ginásio incompleto, $14 \%$ têm ginásio completo/colegial incompleto, $19 \%$ têm colegial completo/superior incompleto e $13 \%$ têm o superior completo.

Tabela 28 - Distribuição da freqüência com que as diferentes faixas etárias dos clientes foram citadas como importantes em cada região, sob a perspectiva do canal de distribuição

\begin{tabular}{lc}
\hline & \\
\hline Abaixo de 20 anos & Brasil \\
Entre 20 e 30 anos & -- \\
Entre 30 e 45 anos & $10 \%$ \\
Acima de 45 anos & $77 \%$ \\
Total & $13 \%$ \\
\hline
\end{tabular}

Fonte: Resultado da pesquisa

Tabela 29 - Distribuição da frequiência com que as principais fontes de renda foram citadas como importantes em cada região, sob a perspectiva do canal de distribuição

\begin{tabular}{lc}
\hline & Brasil \\
\hline Apenas pecuária & $10 \%$ \\
Pecuária e atividade agrícola & $55 \%$ \\
Pecuária e outras atividades desenvolvidas na zona urbana & $31 \%$ \\
Atividades não agrícolas & $4 \%$ \\
\hline Total & $100 \%$ \\
\hline
\end{tabular}

Fonte: Resultado da pesquisa 
Ainda conforme a percepção do canal de distribuição, o produtor é o principal agente que vai ao ponto de venda em todo o Brasil (Tabela 30).

Tabela 30 - Distribuição da freqüência, em porcentagem, com que os agentes foram citados como importantes, sob a perspectiva do canal de distribuição

\begin{tabular}{lccccc}
\hline & $1^{\circ}$ Lugar & $2^{\circ}$ Lugar & $3^{\circ}$ Lugar & $4^{\circ}$ Lugar & $5^{\circ}$ Lugar \\
\hline Produtor & $82 \%$ & $8 \%$ & $4 \%$ & $5 \%$ & - \\
Administrador & $13 \%$ & $56 \%$ & $27 \%$ & $4 \%$ & - \\
Veterinário & $3 \%$ & $17 \%$ & $25 \%$ & $47 \%$ & $40 \%$ \\
Peão & -- & $17 \%$ & $39 \%$ & $42 \%$ & $20 \%$ \\
Outros & $2 \%$ & $2 \%$ & $5 \%$ & $2 \%$ & $40 \%$ \\
\hline Total & $100 \%$ & $100 \%$ & $100 \%$ & $100 \%$ & $100 \%$ \\
\hline
\end{tabular}

Fonte: Resultado da pesquisa

Exemplo de outros: carreteiro, consumidor urbano/criadores de cães, leiteiro, filho, esposa

Sob a percepção do canal de distribuição, para $82 \%$ das empresas o veterinário só é chamado à propriedade nos casos de emergência. Caracterizou-se, assim, que o sistema brasileiro de criação ainda está aquém do ideal, em que o médico veterinário prestaria assistência técnica preventiva. Dos que responderam que o veterinário vai com freqüência à propriedade orientar o manejo, $44 \%$ eram provenientes do Sudeste, $14 \%$ do Sul, $14 \%$ do Nordeste e $28 \%$ do Centro Oeste. No Sudeste, $75 \%$ das empresas responderam que o veterinário só é chamado nos casos de emergência, $12,5 \%$ responderam que o veterinário é chamado com freqüência para orientar o manejo e $12,5 \%$ consideram que o produtor rural não costuma chamar o veterinário. Dos questionários respondidos que os produtores não costumam chamar o veterinário $44 \%$ proveniam da região Sudeste (Tabela 31). 
Tabela 31 - Distribuição da freqüência, em porcentagem, com que o veterinário é chamado à propriedade rural nas diferentes regiões, sob a perspectiva do canal de distribuição

\begin{tabular}{lcccc}
\hline & $\begin{array}{c}\text { Com freqüência para } \\
\text { orientar o manejo }\end{array}$ & $\begin{array}{c}\text { Só em caso de } \\
\text { emergência }\end{array}$ & $\begin{array}{c}\text { Não costumam chamar } \\
\text { o veterinário }\end{array}$ & Total \\
\hline Sudeste & $44 \%$ & $30 \%$ & $44 \%$ & $(32 \%)$ \\
Sul & $(12,5 \%)$ & $(75 \%)$ & $(12,5 \%)$ & \\
& $14 \%$ & $31 \%$ & $28 \%$ & $(30 \%)$ \\
Centro - Oeste & $(4 \%)$ & $(87 \%)$ & $(9 \%)$ & \\
& $28 \%$ & $34 \%$ & $28 \%$ & $(33 \%)$ \\
Nordeste & $(8 \%)$ & $(84 \%)$ & $(8 \%)$ & \\
& $14 \%$ & $5 \%$ & $-\cdots$ & $(5 \%)$ \\
Total & $(25 \%)$ & $(75 \%)$ & $-\cdots$ & \\
\hline
\end{tabular}

Fonte: Resultado da pesquisa

A principal finalidade da compra de produtos veterinários é para uso imediato, como pode ser visualizado na Tabela 32 , em que $90 \%$ das empresas responderam que o produtor de leite vai à loja comprar para este fim. $O$ mesmo ocorre na eqüinocultura, com 91\% dos entrevistados. Dos que afirmaram comprar para estoque, $44 \%$ provinham do Centro Oeste, que possui várias propriedades distantes de centros urbanos e portanto, fazer estoque é uma necessidade. No Sudeste, $95 \%$ responderam que as compras são de uso imediato na pecuária de leite, bem como $81 \%$ das compras na eqüinocultura. Tabela 32 - Distribuição da freqüência de finalidade de compra nas diferentes regiões, sob a perspectiva do canal de distribuição

\begin{tabular}{lcccc}
\hline & \multicolumn{3}{c}{ Pecuária de leite } & \multicolumn{1}{c}{ Eqüinocultura } \\
\hline & Uso imediato & Estoque & Uso imediato & Estoque \\
\hline Sudeste & $30 \%$ & $14 \%$ & $25 \%$ & $58 \%$ \\
& $(95 \%)$ & $(5 \%)$ & $(81 \%)$ & $(19 \%)$ \\
Sul & $32 \%$ & $28 \%$ & $34 \%$ & $14 \%$ \\
& $(91 \%)$ & $(9 \%)$ & $(96 \%)$ & $(4 \%)$ \\
Centro - Oeste & $32 \%$ & $44 \%$ & $35 \%$ & $14 \%$ \\
& $(88 \%)$ & $(12 \%)$ & $(96 \%)$ & $(4 \%)$ \\
Nordeste & $6 \%$ & $14 \%$ & $6 \%$ & $14 \%$ \\
& $(80 \%)$ & $(20 \%)$ & $(80 \%)$ & $(20 \%)$ \\
\hline Total & $90 \%$ & $10 \%$ & $91 \%$ & $9 \%$ \\
\hline
\end{tabular}

Fonte: Resultado da pesquisa 
Quanto à decisão de compra de medicamentos, os pecuaristas de leite ao comprar antiparasitários consideram em primeira instância preço e, em seguida, qualidade. $O$ mesmo ocorre com antibióticos (Tabela 33).

Tabela 33 - Distribuição da frequiência dos atributos considerados importantes pelo consumidor na decisão de compra na pecuária leiteira, sob a visão do canal de distribuição

\begin{tabular}{|c|c|c|c|c|c|}
\hline & & $1^{\circ}$ Lugar & $2^{\circ}$ Lugar & $3^{\circ}$ Lugar & $4^{\circ}$ Lugar \\
\hline \multirow{11}{*}{ Antiparasitários } & Qualidade & $40 \%$ & $31 \%$ & $20 \%$ & $9 \%$ \\
\hline & Inovação tecnológica & -- & -- & $16 \%$ & $6 \%$ \\
\hline & Preço & $41 \%$ & $38 \%$ & $9 \%$ & $7 \%$ \\
\hline & Serviço pós-venda & -- & -- & -- & $3 \%$ \\
\hline & Facilidade de aplicação & -- & $7 \%$ & $9 \%$ & $21 \%$ \\
\hline & Design da embalagem & -- & -- & -- & -- \\
\hline & Período de carência & $11 \%$ & $16 \%$ & $20 \%$ & $12 \%$ \\
\hline & Tempo de latência & $2 \%$ & $4 \%$ & $5 \%$ & $21 \%$ \\
\hline & Marca & $2 \%$ & $4 \%$ & $16 \%$ & $12 \%$ \\
\hline & Não abortivo & $4 \%$ & -- & $5 \%$ & $9 \%$ \\
\hline & Total & $100 \%$ & $100 \%$ & $100 \%$ & $100 \%$ \\
\hline \multirow{11}{*}{ Antibióticos } & Qualidade & $40 \%$ & $30 \%$ & $16 \%$ & $6 \%$ \\
\hline & Inovação tecnológica & -- & $4 \%$ & $7 \%$ & $19 \%$ \\
\hline & Preço & $44 \%$ & $36 \%$ & $11 \%$ & $2 \%$ \\
\hline & Serviço pós-venda & -- & $4 \%$ & -- & $6 \%$ \\
\hline & Facilidade de aplicação & $2 \%$ & $4 \%$ & $18 \%$ & $19 \%$ \\
\hline & Design da embalagem & -- & -- & -- & $2 \%$ \\
\hline & Período de carência & $9 \%$ & $11 \%$ & $28 \%$ & $3 \%$ \\
\hline & Tempo de latência & -- & $4 \%$ & $5 \%$ & $19 \%$ \\
\hline & Marca & $5 \%$ & $5 \%$ & $9 \%$ & $12 \%$ \\
\hline & Não abortivo & -- & $2 \%$ & $6 \%$ & $12 \%$ \\
\hline & Total & $100 \%$ & $100 \%$ & $100 \%$ & $100 \%$ \\
\hline
\end{tabular}

Fonte: Resultado da pesquisa

Ainda segundo o canal de distribuição, a qualidade foi considerada o fator decisório de compras na eqüinocultura, tanto para antiparasitários como para antibióticos (Tabela 34). Em segundo lugar, apontam o preço e poucos consideram outros fatores, como inovação tecnológica, marca e tempo de latência. Para antibióticos, $64 \%$ dos canasi de distribuição consideram qualidade fator decisório de compra, $21 \%$ acreditam ser preço o 
que os criadores levam mais em consideração e $10 \%$ responderam ser a marca fator decisório de compra.

Tabela 34 - Distribuição da freqüência com que os atributos foram citados como importantes na decisão de compra na eqüinocultura, sob a perspectiva do canal de distribuição

\begin{tabular}{|c|c|c|c|c|c|}
\hline & & $1^{\circ}$ Lugar & $2^{\circ}$ Lugar & $3^{\circ}$ Lugar & $4^{\circ}$ Lugar \\
\hline & Qualidade & $62 \%$ & $30 \%$ & $7 \%$ & - \\
\hline & Inovação tecnológica & $2 \%$ & $7 \%$ & $25 \%$ & $14 \%$ \\
\hline & Preço & $26 \%$ & $43 \%$ & $18 \%$ & $7 \%$ \\
\hline \multirow[t]{9}{*}{ Antiparasitários } & Serviço pós-venda & - & $2 \%$ & $3 \%$ & $10 \%$ \\
\hline & Facilidade de aplicação & $3 \%$ & $3 \%$ & $18 \%$ & $28 \%$ \\
\hline & Design da embalagem & -- & $2 \%$ & - & -- \\
\hline & Tempo de latência & $2 \%$ & $3 \%$ & $18 \%$ & $17 \%$ \\
\hline & Marca & $5 \%$ & $10 \%$ & $11 \%$ & $24 \%$ \\
\hline & Total & $100 \%$ & $100 \%$ & $100 \%$ & $100 \%$ \\
\hline & Qualidade & $64 \%$ & $26 \%$ & $8 \%$ & $2 \%$ \\
\hline & Inovação tecnológica & $2 \%$ & $8 \%$ & $27 \%$ & $13 \%$ \\
\hline & Preço & $21 \%$ & $45 \%$ & $12 \%$ & $12 \%$ \\
\hline \multirow[t]{6}{*}{ Antibióticos } & Serviço pós-venda & -- & -- & $6 \%$ & $13 \%$ \\
\hline & Facilidade de aplicação & $3 \%$ & $8 \%$ & $20 \%$ & $22 \%$ \\
\hline & Design da embalagem & -- & -- & -- & $\%$ \\
\hline & Tempo de latência & -- & $5 \%$ & $17 \%$ & $10 \%$ \\
\hline & Marca & $10 \%$ & $8 \%$ & $10 \%$ & $28 \%$ \\
\hline & Total & $100 \%$ & $100 \%$ & $100 \%$ & $100 \%$ \\
\hline
\end{tabular}

Fonte: Resultado da pesquisa 


\subsection{Comunicação utilizada pelas empresas}

\subsubsection{Investimento em Comunicação}

Das empresas entrevistadas, que trabalham com a linha de antiparasitários, $80 \%$ responderam, quando perguntadas sobre a porcentagem do faturamento bruto destinado ao Marketing, investir mais que quatro por cento (Tabela 35).

Das empresas que trabalham com antibióticos, $82 \%$ das empresas responderam investir mais que quatro por cento do faturamento bruto da empresa em marketing (Tabela 35).

Tabela 35 - Distribuição da freqüência das empresas versus Investimento em Marketing

\begin{tabular}{l|ccc}
\hline Marketing/ & \multicolumn{3}{|c}{ Porcentagem do faturamento bruto investido em Marketing } \\
\cline { 2 - 4 } Produto & $1-3 \%$ & $4-6 \%$ & Mais de 6\% \\
\hline Antiparasitários & $20 \%$ & $40 \%$ & $40 \%$ \\
\hline Antibióticos & $18 \%$ & $64 \%$ & $18 \%$ \\
\hline
\end{tabular}

Fonte: Entrevista junto às empresas

Mais que $50 \%$ das empresas, quando questionadas a que ponto conhecem as necessidades dos clientes, responderam não as conhecerem totalmente. Das empresas que trabalham com antiparasitários, $30 \%$ disseram conhecer todas as necessidades dos consumidores, enquanto as $70 \%$ restantes dividem-se entre conhecer razoavelmente, ter noção das necessidades e não saber direito (Gráfico 7).

No que se refere aos antibióticos, $18 \%$ das empresas responderam conhecer todas as necessidades, contra $82 \%$ que responderam ter noção ou conhecer razoavelmente (Gráfico 8). 
Gráfico 7 - Conhecimento das empresas quanto às necessidades do consumidor para antiparasitários

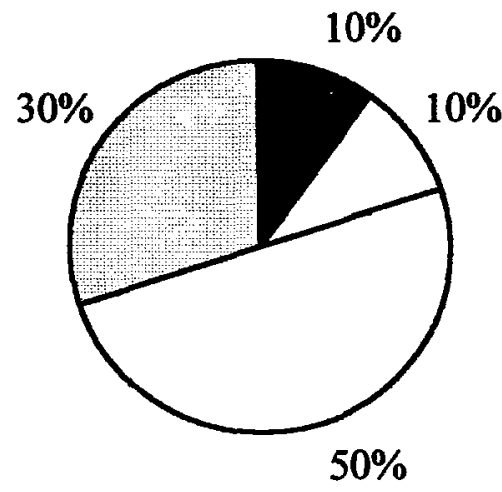

Não sabem direto
$\square$ Têm noção
$\square$ Conhecem
razavelmente
$\square$ Conhecem bem

Fonte: Elaborado pela autora

Gráfico 8 - Conhecimento das empresas quanto às necessidades do consumidor para antibióticos

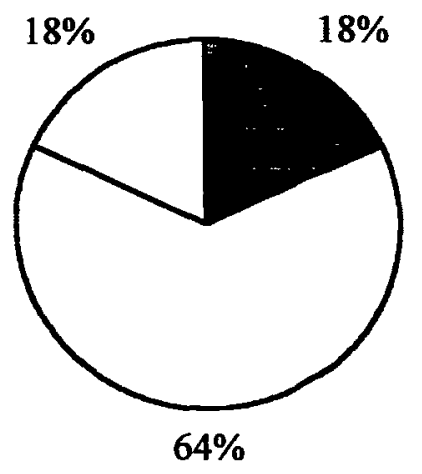

Têm noção

Conhecem razoavelmente

$\square$ Conhecem bem

Fonte: Elaborado pela autora 


\subsubsection{Formas de comunicação}

Os resultados obtidos junto às empresas mostram que as formas de comunicação mais utilizadas são: merchandising em pontos de vendas e revistas especializadas (Tabela 36). Há algumas diferenças regionais como a maior utilização de jornais de cooperativas no Sudeste e Sul, quando comparado ao Centro-Oeste, e a maior utilização do rádio, como canal de comunicação, no Sul.

Tabela 36 - Distribuição da freqüência das diferentes formas de comunicação que foram citadas como adotadas em 1998 pelas empresas

\begin{tabular}{lllll}
\hline Produto & Formas de comunicação utilizada & Sul & Sudeste & Centro Oeste \\
\hline & TV & $20 \%$ & $20 \%$ & $20 \%$ \\
& Revista especializada & $70 \%$ & $70 \%$ & $70 \%$ \\
Antiparasitários & Revista não especializada & $0 \%$ & $0 \%$ & $0 \%$ \\
& Jornais de grande circulação & $10 \%$ & $10 \%$ & $10 \%$ \\
& Jornais regionais & $40 \%$ & $40 \%$ & $30 \%$ \\
& Jornais de cooperativas & $60 \%$ & $70 \%$ & $40 \%$ \\
& Rádio & $40 \%$ & $30 \%$ & $30 \%$ \\
& Mala direta & $70 \%$ & $70 \%$ & $80 \%$ \\
& Merchandising em ponto de venda & $90 \%$ & $90 \%$ & $90 \%$ \\
& Outros & $10 \%$ & $10 \%$ & $10 \%$ \\
\hline \multirow{5}{*}{ Antibióticos } & $9 \%$ & $9 \%$ & $9 \%$ \\
& TV & $72 \%$ & $72 \%$ & $72 \%$ \\
& Revista especializada & $0 \%$ & $0 \%$ & $0 \%$ \\
& Revista não especializada & $0 \%$ & $0 \%$ & $0 \%$ \\
& Jornais de grande circulação & $45 \%$ & $45 \%$ & $18 \%$ \\
& Jornais regionais & $63 \%$ & $72 \%$ & $27 \%$ \\
& Jornais de cooperativas & $36 \%$ & $27 \%$ & $18 \%$ \\
& Rádio & $63 \%$ & $63 \%$ & $45 \%$ \\
& Mala direta & $81 \%$ & $81 \%$ & $81 \%$ \\
& Merchandising em ponto de venda & $9 \%$ & $9 \%$ & $9 \%$ \\
\hline
\end{tabular}

Fonte: Resultado da pesquisa

No resultado do perfil do consumidor de insumos agropecuários (ABMR, 1998/1999) a televisão despontou como o melhor meio de divulgação de mensagens sobre novos lançamentos, usos, características de produtos, máquinas e equipamentos no meio rural, 
com $40 \%$ dos votos. Em segundo lugar veio demonstração do produto/dias de campo com $12 \%$, rádio com $12 \%$, reuniões técnicas com $10 \%$, jornais de cooperativas com $7 \%$ e mala direta $\operatorname{com} 6 \%$.

Em relação ao merchandising no ponto de venda, quase todas as empresas entrevistadas utilizam esta forma de comunicação (Tabela 37). Treinamento para balconista e promoção com prêmios para balconistas foram considerados, também, como formas eficazes para vendas de antiparasitários e antibióticos.

Tabela 37 - Medida de tendência central ${ }^{*}$ das formas de merchandising por categoria de produto utilizados pelas empresas

\begin{tabular}{lcc}
\hline & Antiparasitários & Antibióticos \\
\hline Banner & 3 & 3 \\
Cartaz para balcão & 2 & 2 \\
Folhetos & 1 & 3 \\
Treinamento para balconista & 1 & 1 \\
Promoção com prêmios p/ balconista & 1 & 1 \\
\hline
\end{tabular}

* Calculado pela moda

Fonte: Resultado da pesquisa

As formas de comunicação listadas acima são as tradicionais preconizadas pelo planejamento de vendas. Uma alternativa de comunicação direta com o consumidor também apontada é o oferecimento de serviços de pós-venda, mesmo quando não é realizado venda direta. Essa estratégia visa aumentar o contato da empresa com o consumidor e permite perceber melhor a necessidade e o desejo do mercado.

No caso de antiparasitários para bovinocultura de leite, $33 \%$ das empresas fazem venda direta ao consumidor e agregam serviço pós-venda. Tais serviços são constituídos por análise laboratorial, atendimento telefônico para dúvidas, aplicação do produto, acompanhamento técnico do manejo e outros. Das empresas entrevistadas, $45 \%$ não realizam venda direta de antiparasitários e não oferecem serviços de pós-venda (Figura 7). 
Das empresas que comercializam antibióticos para bovinocultura, $18 \%$ fazem venda direta ao consumidor e oferecem serviços pós-venda, contra $55 \%$ que não o fazem (Figura 8).

Figura 7 - Venda direta de antiparasitários para bovinocultura de leite

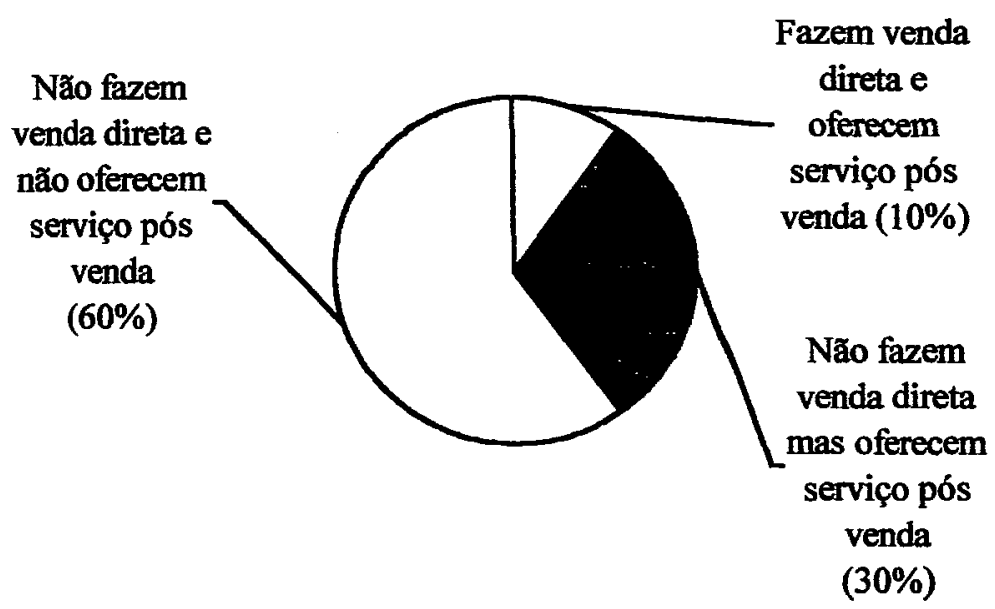

Fonte: Elaborado pela autora

Figura 8 - Venda direta de antibióticos para bovinocultura de leite

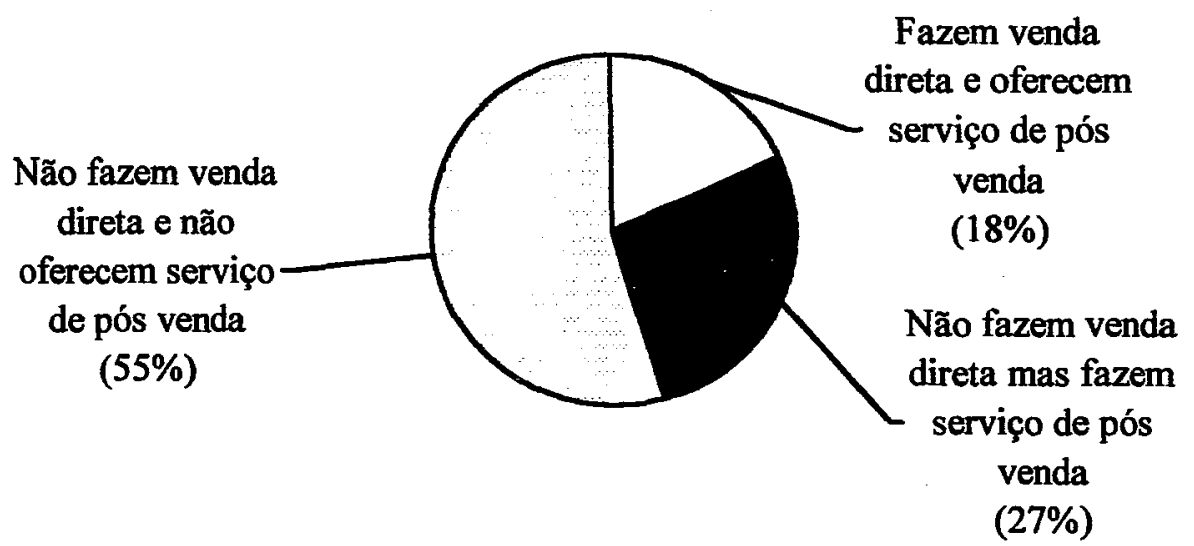

Fonte: Elaborado pela autora 
$\mathrm{Na}$ eqüinocultura, $14 \%$ das empresas que comercializam antiparasitários disseram realizar venda direta ao consumidor e oferecem serviço pós-venda, enquanto $57 \%$ não o fazem e tampouco oferecem serviço de pós-venda (Figura 9). O mesmo ocorre para antibióticos, onde mais de $\mathbf{5 0 \%}$ das empresas entrevistadas não oferecem de pós-venda nem fazem venda direta ao consumidor (Figura 10).

Figura 9 - Venda direta de antiparasitários para Eqüinocultura

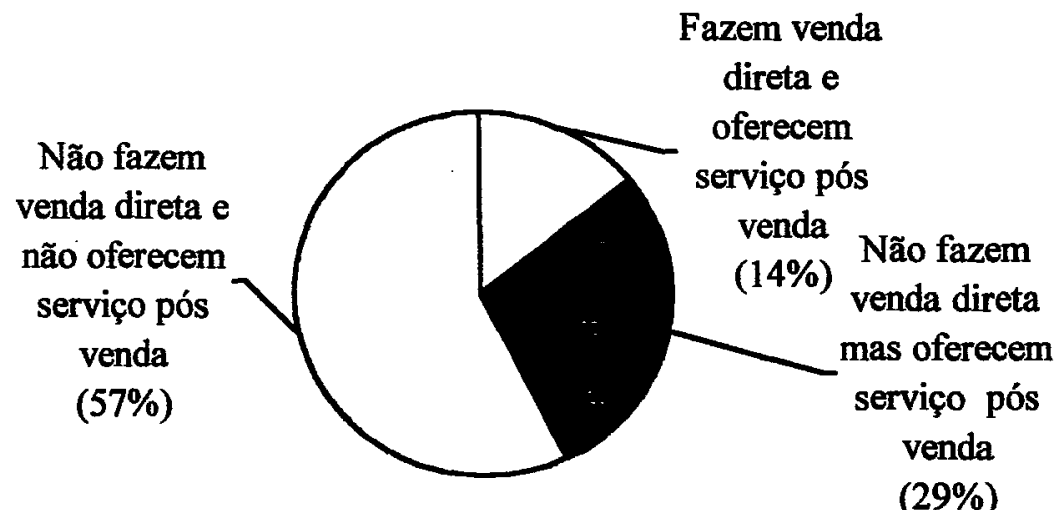

Fonte: Elaborado pela autora

Figura 10 - Venda direta de antibióticos para Eqüinocultura

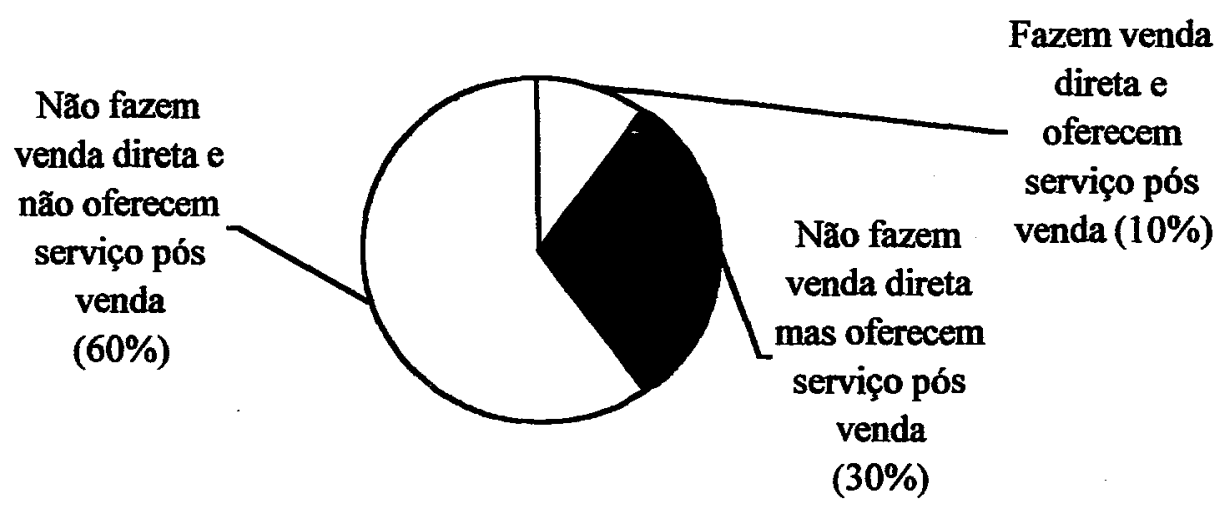

Fonte: Elaborado pela autora 


\subsubsection{Comunicação eficaz sob a perspectiva dos canais de distribuição}

\subsubsection{Pecuária de leite}

Os resultados dos questionários indicam que $49 \%$ dos canais de distribuição consideram a televisão a forma mais eficaz de atingir o pecuarista de leite, enquanto $19 \%$ consideram a propaganda no ponto de venda como a forma mais importante de comunicação (Tabela 38). Das empresas entrevistadas, apenas vinte por cento responderam utilizar televisão como veículo de comunicação e $90 \%$ delas utilizam merchandising no ponto de venda. Figura em segundo lugar, a revista especializada.

Tabela 38 - Distribuição da freqüência com que as formas de comunicação foram consideradas mais eficazes para pecuária de leite de acordo com o canal de distribuição

\begin{tabular}{lcccc}
\hline & $1^{\circ}$ Lugar & $\mathbf{2}^{\circ}$ Lugar & $3^{\circ}$ Lugar & $4^{\circ}$ Lugar \\
\hline TV & $49 \%$ & $12,5 \%$ & $11 \%$ & $5 \%$ \\
Revista especializada & $7 \%$ & $25 \%$ & $14 \%$ & $14 \%$ \\
Revista não especializada & $2 \%$ & $0 \%$ & $0 \%$ & $5 \%$ \\
Jornais de grande circulação & $2 \%$ & $5,5 \%$ & $18 \%$ & $2 \%$ \\
Jornais regionais & $2 \%$ & $0 \%$ & $7 \%$ & $9 \%$ \\
Jornais de cooperativas & $7 \%$ & $7 \%$ & $16 \%$ & $20 \%$ \\
Rádio & $5 \%$ & $16 \%$ & $14 \%$ & $14 \%$ \\
Mala direta & $7 \%$ & $16 \%$ & $11 \%$ & $18 \%$ \\
Propaganda em ponto de venda & $19 \%$ & $18 \%$ & $9 \%$ & $13 \%$ \\
\hline Total & $100 \%$ & $100 \%$ & $100 \%$ & $100 \%$ \\
\hline
\end{tabular}

Fonte: Resultado da pesquisa

Fica claro que a televisão e a propaganda em pontos de venda são as formas mais relevantes. Em segundo lugar, estão as revistas especializadas, à exceção do Sudeste onde o jornal de cooperativa é o segundo colocado.

Quanto às formas de comunicação mais eficientes nos pontos de venda, as palestras técnicas para clientes e veterinários foram as formas consideradas eficazes de acordo com o canal de distribuição, seguida pelo treinamento do balconista (Tabela 39). 
Tabela 39 - Distribuição da freqüência das formas de comunicação consideradas mais eficazes junto aos pecuaristas de leite de acordo com o canal de distribuição

\begin{tabular}{lcccc}
\hline & $\mathbf{1}^{\circ}$ Lugar & $\mathbf{2}^{\circ}$ Lugar & $\mathbf{3}^{\circ}$ Lugar & $\mathbf{4}^{\circ}$ Lugar \\
\hline Cartazes de parede & $\mathbf{2 \%}$ & $\mathbf{2 \%}$ & $\mathbf{2 \%}$ & $3 \%$ \\
Cartaz de balcão & $2 \%$ & $3 \%$ & $3 \%$ & $3 \%$ \\
Folhetos & $0 \%$ & $2 \%$ & $2 \%$ & $11 \%$ \\
Treinamento para balconista & $30 \%$ & $11 \%$ & $29 \%$ & $7 \%$ \\
Promoção com prêmios para balconista & $7 \%$ & $16 \%$ & $9 \%$ & $22 \%$ \\
Expositores para produtos & $0 \%$ & $3 \%$ & $7 \%$ & $9 \%$ \\
Palestras técnicas p/ clientes e veterinários & $41 \%$ & $23 \%$ & $19 \%$ & $7 \%$ \\
Distribuição de amostra grátis & $5 \%$ & $11 \%$ & $9 \%$ & $17 \%$ \\
Serviço técnico de atendimento ao cliente & $11 \%$ & $26 \%$ & $11 \%$ & $12 \%$ \\
Participação em feiras e exposições & $2 \%$ & $3 \%$ & $9 \%$ & $9 \%$ \\
\hline Total & $100 \%$ & $100 \%$ & $100 \%$ & $100 \%$ \\
\hline
\end{tabular}

Fonte: Resultado da pesquisa

\subsubsection{Eqüinocultura}

Na eqüinocultura, assim como na pecuária de leite, o canal de distribuição considera a televisão o veículo de comunicação mais importante, seguida pelas revistas especializadas (Tabela 40).

Tabela 40 - Distribuição da freqüência das formas de divulgação e promoção consideradas como as mais importantes na Eqüinocultura pelo canal de distribuição

\begin{tabular}{lcccc}
\hline & $1^{\circ}$ Lugar & $2^{\circ}$ Lugar & $3^{\circ}$ Lugar & $4^{\circ}$ Lugar \\
\hline TV & $44 \%$ & $19 \%$ & $10 \%$ & $5 \%$ \\
Revista especializada & $23 \%$ & $34 \%$ & $15 \%$ & $12 \%$ \\
Revista não especializada & $0 \%$ & $0 \%$ & $0 \%$ & $7 \%$ \\
Jornais de grande circulação & $0 \%$ & $5 \%$ & $15 \%$ & $12 \%$ \\
Jornais regionais & $2 \%$ & $0 \%$ & $8 \%$ & $10 \%$ \\
Jornais de cooperativas & $3 \%$ & $3 \%$ & $12 \%$ & $10 \%$ \\
Rádio & $3 \%$ & $14 \%$ & $5 \%$ & $14 \%$ \\
Mala direta & $10 \%$ & $17 \%$ & $20 \%$ & $14 \%$ \\
Propaganda em ponto de venda & $15 \%$ & $8 \%$ & $15 \%$ & $16 \%$ \\
\hline Total & $100 \%$ & $100 \%$ & $100 \%$ & $100 \%$ \\
\hline
\end{tabular}

Fonte: Resultado da pesquisa 
Quanto às formas de propaganda nos pontos de venda, o meio de comunicação considerado mais importante pelo canal de distribuição foi palestra técnica para veterinários com $39 \%$ dos votos. Entre os agentes de distribuição, $23 \%$ consideram treinamento para balconista fundamental e $21 \%$ consideram a participação em provas eqüestres a principal forma de divulgação de medicamentos para a eqüinocultura (Tabela 41).

Tabela 41 - Distribuição da freqüência das formas de propaganda consideradas como as mais importantes na Eqüinocultura pelo canal de distribuição

\begin{tabular}{lcccc}
\hline & $\mathbf{1}^{\circ}$ Lugar & $\mathbf{2}^{\circ}$ Lugar & $\mathbf{3}^{\circ}$ Lugar & $\mathbf{4}^{\circ}$ Lugar \\
\hline Cartazes de parede & $\mathbf{4} \%$ & $4 \%$ & $5 \%$ & $9 \%$ \\
Cartaz de balcão & $0 \%$ & $7 \%$ & $9 \%$ & $15 \%$ \\
Folhetos & $0 \%$ & $2 \%$ & $18 \%$ & $20 \%$ \\
Treinamento p/ balconista & $23 \%$ & $20 \%$ & $25 \%$ & $13 \%$ \\
Promoção c/ prêmios p/ balconista & $13 \%$ & $9 \%$ & $16 \%$ & $18 \%$ \\
Expositores p/ produtos & $0 \%$ & $5 \%$ & $13 \%$ & $9 \%$ \\
Participação de provas eqüestres & $21 \%$ & $24 \%$ & $7 \%$ & $9 \%$ \\
Palestras para veterinários & $39 \%$ & $29 \%$ & $7 \%$ & $7 \%$ \\
Outros & $0 \%$ & $0 \%$ & $0 \%$ & $0 \%$ \\
\hline Total & $100 \%$ & $100 \%$ & $100 \%$ & $100 \%$ \\
\hline
\end{tabular}

Fonte: Resultado da pesquisa 


\section{CONCLUSÃo}

O mercado farmacêutico veterinário, assim como o mercado farmacêutico humano, segue a tendência de se concentrar, por meio de fusões e aquisições, numa busca de redução dos altos custos de descobertas científicas, redução dos investimentos em construção de marcas de sucesso e expansão dos mercados globais. No Brasil o mercado farmacêutico veterinário sofreu influências das fusões ocorridas nos últimos anos, caracterizando-se pelo crescimento da participação das vendas das multinacionais no mercado nacional.

Nos paises desenvolvidos o crescimento quantitativo estagnou-se, abrindo apenas a possibilidade da ampliação de consumo qualitativo, no caso das drogas que provêem valor agregado aos seus consumidores. $O$ sucesso de uma droga depende de ser o primeiro a lançá-la, da comprovação dos ganhos terapêuticos obtidos com ela e da habilidade da empresa em adotar estratégias de mercado voltadas para o marketing, utilizando a mídia popular como o principal veículo de lançamento de medicamentos.

As drogas das quais se espera maior sucesso são as de alto valor agregado, moléculas de última geração, atendendo às mudanças dos hábitos alimentares e sociais dos animais. Dedicando-lhes maior atenção, os proprietários, investem grandes quantias de sua renda no bem estar do animal e na melhoria do convívio humano com os animais.

Estima-se que as vacinas, antiparasitários e especialidades apresentem um crescimento de destaque nesta próxima década. Drogas para controle de pulga no animal e no ambiente ganham destaque, assim como drogas que atendam às crescentes exigências de especializações médicas veterinárias. Assim, o principal mercado consumidor com potencial de crescimento mundialmente indubitavelmente é o de animais de companhia, representado por cães, gatos e eqüinos. 
De modo bastante específico, o mercado mundial avícola e o suíno sofrerão, certamente, os impactos provenientes de futuras restrições ao uso de antimicrobianos como aditivos alimentares, devendo-se estar atento a possíveis substitutos que estão sendo desenvolvidos no exterior.

Com essa briga, o Brasil tem oportunidade de suprir países que, outrora atendidos por produção européia ou americana, não possam mais ser supridos eficientemente. Em contrapartida, mercados consumidores dos países desenvolvidos exigirão de seus fornecedores material de procedência com a garantia da ausência de aditivos, o que pode forçar parte da produção avícola e suína a se adaptarem.

Quanto ao mercado consumidor brasileiro, o "cliente final" caracteriza-se por possuir como principal fonte de renda a pecuária e a atividade agrícola. Concentra-se na faixa etária entre 30 e 45 anos e, segundo a percepção dos canais de distribuição, o agente que mais vai ao ponto de venda é o próprio produtor. Os principais produtos consumidos são os antiparasitários e os biológicos, consumo destes fortemente influenciado por fatores climáticos. Constata-se ainda que, no Brasil, o aumento do consumo de medicamento para animais de companhia segue tendências mundiais.

Quanto aos canais de distribuição utilizados pelas empresas, não há uma concentração no uso de um tipo específico de distribuição. Na grande maioria, utilizam-se todos os canais, embora se note uma preferência pelos específicos, dependendo do consumidor final, da região ou de ser o produto uma commodity ou uma especialidade. $\mathrm{Na}$ eqüinocultura, diferentemente, os canais exclusivos de distribuição se destacam, caracterizando um sistema especializado cuja agregação de valor ao produto pelo agente é necessária. $\mathrm{Na}$ bovinocultura de leite, por sua vez, confere-se a mesma importância aos distribuidores exclusivos e às revendas para a comercialização de produtos, o que caracteriza a presença de segmentos consumidores especializados e não especializados neste setor.

Para produtos genéricos, não há a necessidade de se trabalhar com canal de distribuição especializado, já que a comunicação é mais dinâmica e a integração empresa com o canal de distribuição não é fator decisivo para o sucesso do produto. Preço e promoção são os principais fatores competitivos, diferentemente do que ocorre com os 
produtos denominados especialidades, que requerem maior especialização dos canais de distribuição. Tais canais podem colaborar com o sucesso do produto ao conferir maior atenção a nichos do mercado e à fixação da marca, variáveis fundamentais para o sucesso desta classe de medicamentos.

Quanto à importância regional, para antiparasitários e antibióticos, a revenda é considerada um importante canal no Centro-Oeste, Nordeste e Norte. No Sul, vendedores próprios e revendas são importantes. No Sudeste, os distribuidores exclusivos são representativos.

Quanto à comunicação, o canal de distribuição assume um importante papel por ser o balconista o principal "agente influenciador" na compra de antiparasitários. Na venda de antibióticos para a pecuária de leite e para a eqüinocultura, por serem um produto que exige maior agregação de valor no ato da venda, o principal agente passa a ser o veterinário, tornando-se ele um "facilitador" de comunicação entre os canais de distribuição e as empresas. Apesar de serem considerados importantes agentes na transação de medicamentos, os resultados evidenciam que os veterinários ainda têm pouco poder de decisão sobre todo o sistema, sendo chamados à propriedade geralmente em casos de emergência.

A visão que as empresas e os canais de distribuição têm do consumidor final de medicamento se diverge quando enumeram os principais atributos oferecidos pelos produtos. As empresas consideram igualmente importantes preço e qualidade na venda de antiparasitários para a bovinocultura de leite, enquanto os canais consideram o preço como o mais importante fator decisório de compra. Quanto aos atributos considerados importantes na venda de antibióticos para a pecuária de leite, as empresas consideram mais importante qualidade, e os canais de distribuição consideram preço. $\mathrm{Na}$ equiuinocultura, no entanto, as opiniões das empresas e dos canais de distribuição sobre os principais atributos decisórios de compra convergem. Ambos consideram fator decisivo de compra a qualidade, tanto para antiparasitários como para antibióticos.

Essa diferença de opiniões sugere que as empresas não estão sabendo comunicar o valor agregado do produto oferecido aos canais de distribuição ou têm dificuldade de perceber as verdadeiras necessidades dos consumidores. 
As empresas que sinalizaram nas entrevistas obterem sucesso na comunicação com os "consumidores finais" foram aquelas que demonstraram ter os melhores elos com os canais de distribuição, apresentando estratégias coordenadas de mercado, linha de produto e comunicação.

No Brasil, as empresas farmacêuticas veterinárias alegam apresentar dependência do canal de distribuição para obterem as características da demanda do consumidor final. Procuram trabalhar com todos os tipos de canais de distribuição, evitando dependência numa única forma. O canal de distribuição, por muitas empresas, não é considerado como um composto mercadológico que oferece vantagens competitivas, de fato são considerados como barreiras de entrada. Os motivos que levam a essas considerações devem ser melhor estudados, focalizando-se, principalmente, os elos da cadeia de valores, fluxo e coordenação de informação.

As vendas diretas, como formas de integração do consumidor final com as empresas, representam pouco do volume total de vendas. E o serviço pós-venda, que poderia ser também uma estratégia de integração, é mais ofertado na bovinocultura do que na eqüinocultura, apesar de ser este um segmento mais especializado.

A maioria das empresas farmacêuticas veterinárias não faz diferença entre comunicação para o canal e comunicação para o produtor. De um modo geral, segundo as entrevistas, pode-se dizer que, para a pecuária de leite, a comunicação é mais direcionada aos veterinários e balconistas enquanto, na eqüinocultura, o marketing é mais voltado ao consumidor final. Esse foco da comunicação voltado a diferentes agentes ocorre de acordo com a percepção das empresas sobre quem elas consideram "influenciadores da demanda" para cada atividade.

$\mathrm{O}$ enfoque do marketing varia também de acordo com o tipo de produto. Os produtos genéricos têm o enfoque do marketing maior no canal de distribuição e menor no cliente. Os entrevistados citam o exemplo da maioria dos parasiticidas, cujo marketing deve ser enfatizado no canal, pois tanto as empresas farmacêuticas veterinárias, como os canais de distribuição, consideram-nos como commodities, o que justificaria o direcionamento. Em segmentos com maior exigência qualitativa, existe uma tendência do apoio técnico ser integrante do canal de distribuição. 


\section{Anexos}

Anexo A - Trabalho realizado pela FAEMG e SEBRAE de Minas Gerais, numa amostra de 1.000 produtores da Produção e produtividade do leite nas mesorregiões do Estado de Minas Gerais

\begin{tabular}{|l|l|l|l|}
\hline \multirow{2}{*}{ Messoregiões } & \multicolumn{2}{|l|}{ Produção anual } & $\begin{array}{l}\text { Produtividade } \\
\text { litros/ano/vaca/ } \\
\text { ordenhada }\end{array}$ \\
\cline { 2 - 4 } & Mil litros & $\%$ & 775 \\
\hline Triângulo/Alto Paranaíba & 1.012 .908 & 22,50 & 1.231 \\
\hline Sul/Sudeste & 833.737 & 18,52 & 1.206 \\
\hline Mata & 553.660 & 12,30 & 793 \\
\hline Vale do Rio Doce & 379.953 & 8,44 & 1.029 \\
\hline Metropolitana de BH & 308.379 & 6,85 & 1.048 \\
\hline Oeste de MG & 287.672 & 6,40 & 1.018 \\
\hline Central mineira & 269.259 & 5,98 & 1.536 \\
\hline Campos das Vertentes & 251.858 & 5,59 & 619 \\
\hline Nordeste de Minas & 180.389 & 4,01 & 476 \\
\hline Norte de Minas & 179.840 & 3,99 & 582 \\
\hline Jequitinhonha & 143.101 & 3,17 & 568 \\
\hline Vale do Mucuri & 101.899 & 2,25 & 897 \\
\hline Minas Gerais & 4.502 .655 & 100,00 & \\
\hline
\end{tabular}

Fonte: Pesquisa Direta, SEBRAE-MG/FAEMG 
Anexo B - Número relativo à produção de leite por produtor, por vaca ordenhada e por rebanho - Estado de Minas Gerais

\begin{tabular}{|c|c|c|c|c|c|c|c|c|c|c|c|}
\hline \multirow[t]{3}{*}{ Messoregiões } & \multirow{2}{*}{\multicolumn{3}{|c|}{\begin{tabular}{|l} 
Distribuição \\
percentual do \\
número de \\
produtores de \\
leite \\
Estratos de \\
produção de \\
leite \\
(litros/dia)
\end{tabular}}} & \multicolumn{4}{|c|}{$\begin{array}{l}\text { Produção de leite/vaca } \\
\text { ordenhada (dados em } \\
\text { litros por dia) }\end{array}$} & \multicolumn{4}{|c|}{$\begin{array}{l}\text { Número de vacas } \\
\text { ordenhadas/número total } \\
\text { de vacas }\end{array}$} \\
\hline & & & & \multicolumn{4}{|c|}{$\begin{array}{l}\text { Estratos de produção } \\
\text { de leite (litros/dia) }\end{array}$} & \multicolumn{4}{|c|}{$\begin{array}{l}\text { Estratos de produção de } \\
\text { leite (litros/dia) }\end{array}$} \\
\hline & 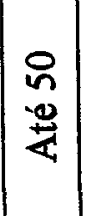 & 号 & 吾 & 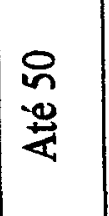 & $\frac{\stackrel{\circ}{n}}{\frac{1}{n}}$ & 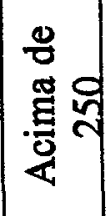 & 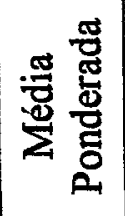 & 号 & 畩 & 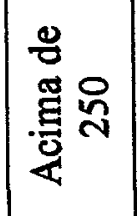 & 焉曾 \\
\hline $\begin{array}{l}\text { Triângulo/ } \\
\text { Alto Paranaíba }\end{array}$ & 41 & 53 & 6 & 3,96 & 5,14 & 7,87 & 4,82 & 64,6 & 68,8 & 67,9 & 67,08 \\
\hline Sul/Sudeste & 61 & 30 & 9 & 3,30 & 7,11 & 11,9 & 5,22 & 59,4 & 67,6 & 74,97 & 63,28 \\
\hline Mata & 71 & 25 & 4 & 3,78 & 4,35 & 8,88 & 4,13 & 63,5 & 68,9 & 68,94 & 65,14 \\
\hline Vale do Rio Doce & 60 & 34 & 6 & 4,54 & 4,22 & 5,07 & 4,46 & 66,6 & 57,1 & 63,94 & 63,25 \\
\hline Metropolitana de $\mathrm{BH}$ & 62 & 32 & 6 & 5,43 & 6,33 & 8,88 & 5,92 & 55,5 & 70,3 & 77,38 & 61,62 \\
\hline Oeste de MG & 58 & 34 & 8 & 3,57 & 6,00 & 7,22 & 4,69 & 60,1 & 68,2 & 72,88 & 63,91 \\
\hline Central Mineira & 62 & 32 & 6 & 5,91 & 6,83 & 10,5 & 6,48 & 65,1 & 64,8 & 77,01 & 65,75 \\
\hline Campos das Vertentes & 61 & 32 & 7 & 4,83 & 6,57 & 8,97 & 5,67 & 76,0 & 68,1 & 78,58 & 73,73 \\
\hline Nordeste de Minas & 73 & 25 & 2 & 3,98 & 5,24 & 10,1 & 4,42 & 41,7 & 64,3 & 74,54 & 48,08 \\
\hline Norte de Minas & 69 & 29 & 2 & 5,18 & 5,12 & 8,48 & 5,23 & 42,6 & 51,4 & 53,70 & 45,43 \\
\hline Jequitinhonha & 74 & 21 & 5 & 2,85 & 3,35 & 4,04 & 3,02 & 65,8 & 52,5 & 41,09 & 61,81 \\
\hline
\end{tabular}

Fonte: Pesquisa Direta, SEBRAE-MG/FAEMG 
Anexo $\mathrm{C}$ - Escalas básicas de medição

\begin{tabular}{|c|c|c|c|}
\hline ESCALA & CARACTERISTICA & $\begin{array}{c}\text { USO EM } \\
\text { MARKETING }\end{array}$ & $\begin{array}{c}\text { ESTATISTICAS } \\
\text { POSSÍVEIS }\end{array}$ \\
\hline Nominal & $\begin{array}{l}\text { Os números servem apenas para } \\
\text { nomear, identificar e/ou } \\
\text { classificar dados sobre pessoas, } \\
\text { objetos ou fatos. Com escalas } \\
\text { nominais, a única operação } \\
\text { possível é a contagem, e por isso, } \\
\text { a moda é a única medida de } \\
\text { tendência central que pode ser } \\
\text { calculada }\end{array}$ & $\begin{array}{l}\text { Marcas, sexo, raças, } \\
\text { cores, tipo de lojas, } \\
\text { região, uso/não uso, } \\
\text { gosta/não gosta, e a } \\
\text { toda variável que se } \\
\text { possararar } \\
\text { números associar } \\
\text { identificação }\end{array}$ & $\begin{array}{l}\text { Moda, } \\
\text { percentagens, teste } \\
\text { binomial, teste } \\
\text { qui-quadrado, } \\
\text { Mcnemar, } \\
\text { Cochran Q }\end{array}$ \\
\hline Ordinal & $\begin{array}{l}\text { Os números servem para nomear, } \\
\text { identificar, categorizar e ordenar, } \\
\text { segundo um processo de } \\
\text { comparação de uma determinada } \\
\text { característica. Esta escala permite } \\
\text { identificar a preferência por uma } \\
\text { marca, mas não quão melhor é } \\
\text { em relação à outra }\end{array}$ & \begin{tabular}{|l|} 
Atitudes, \\
preferências, \\
opiniões, classe \\
social, ocupação \\
\\
\end{tabular} & $\begin{array}{lr}\text { Medianas, } & \text { quartis, } \\
\text { decis, } & \text { percentis, } \\
\text { teste } & \text { Mann- } \\
\text { Whitney, } & \text { teste U, } \\
\text { Kruskal } & \text { Wallis, } \\
\text { correlação } & \text { de } \\
\text { postos } & \end{array}$ \\
\hline Intervalo & $\begin{array}{l}\text { Os intervalos entre os números } \\
\text { indicam a posição e quanto que } \\
\text { as pessoas, objetos ou fatos estão } \\
\text { distantes entre si em relação a } \\
\text { determinada característica. É } \\
\text { possível comparar diferenças } \\
\text { entre medições, mas não é } \\
\text { possível concluir quanto à } \\
\text { magnitude absolutar das } \\
\text { medições, pois não há um zero } \\
\begin{array}{lll}\text { absoluto } \\
\end{array}\end{array}$ & $\begin{array}{l}\text { Atitudes, opiniões, } \\
\text { conscientização, } \\
\text { preferências, número } \\
\text { - indice } \\
\end{array}$ & $\begin{array}{|lr|}\text { Média, intervalo, } \\
\text { amplitude } & \text { total, } \\
\text { amplitude } & \text { média, } \\
\text { desvio } & \text { médio, } \\
\text { variância, desvio } & \\
\text { padrão, teste Z, } \\
\text { teste T, análise da } \\
\text { variância, } \\
\text { correlação } \\
\text { produto de } \\
\text { momento }\end{array}$ \\
\hline Razão & $\begin{array}{l}\text { As escalas razão possuem as } \\
\text { mesmas propriedades das escalas } \\
\text { de intervalo, com a vantagem de } \\
\text { possuir zero absoluto. É possível } \\
\text { concluir a magnitude absoluta } \\
\text { das medidas e informar a posição } \\
\text { que o objeto, pessoa ou fato esta } \\
\text { de uma determinada } \\
\text { característica }\end{array}$ & $\begin{array}{l}\text { Idade, preço, número } \\
\text { de consumidores, } \\
\text { volume de vendas, } \\
\text { renda, patrimônio }\end{array}$ & $\begin{array}{l}\text { Todos os itens } \\
\text { anteriores e mais } \\
\text { media geométrica, } \\
\text { média harmônica e } \\
\text { coeficiente de } \\
\text { variação }\end{array}$ \\
\hline
\end{tabular}

Fonte: Mattar, 1997 


\section{REFERÊNCIAS BIBLIOGRAFICAS}

AAKER, D.A.; KUMAR, V.; DAY, G.S. Marketing Research. $6^{a}$ edição, New York: John Wiley \& Sons, Inc.. 1997. 756p.

ALDEBARÃ. Pesquisa força de vendas veterinárias. São Paulo: Aldebarã, 1998. 74p.

ANIMAL PHARM, London, n. 392, March 6, 1998. 27p.

ASSOCIAÇÃo BRASILEIRA DE MARKETING RURAL. Perfil do consumidor de insumos agropecuários. São Paulo, 1998/1999. 23p.

BAKER, G.A.; CROSBIE, P.J. Consumer Preferences for Food Safety Attribute: A Market Segment Approach. Agribusiness, v.10, n. 4, p. 319-324, 1994.

BRAR, D.S. The international generics marketplace: a new model for competition. Chemical Management Review, p. 61-65, November/December, 1999.

BRUNO, M.A.C. Tecnologia e estratégia das empresas do setor químico: conceitos e tendências. Revista de Administração, São Paulo, v. 30, n. 2, p. 5-17, abril/junho, 1995.

BURBANK, J.R. Designing Performance Measures for productivity and customer satisfaction./ Apresentado ao 1992 ASQS Quality Congress Transaction, Nashville, 1992/ 
CHANG, J. AHP and Monsanto merge to form colossal life science firm. Chemical Market Report, v. 253, n. 23, p. 1-37, Jun. 8, 1998.

CLEMENTS, M. Feeling the benefit of tighter disease control. Animal Pharm: Review of 1997, p. 11-12, 1997.

ESCOLA SUPERIOR DE AGRICULTURA “LUIZ DE QUEIROZ”. Comissão de PósGraduação. Normas para elaboração de dissertaçôes e teses. Piracicaba: ESALQ/USP, 1997. 80p.

FARINA, E.M.M.Q.; ZYLBERSZTAJN, D. Competitividade no Agribusiness Brasileiro. São Paulo, PENSA/FIA/FEA/USP, julho, 1998. 77p.

GERRY, R. It's raining cats and dogs in animal health. Chemical Market Report, v. 252, n. 11, p. 20-24, sep. 15, 1997.

HAYSLIP, W. Measuring Customer Satisfaction in Business Markets. Quality Process. April 1994. 5p.

HOBBS, J.E. Transaction Cost and Slaughter Cattle Procurement: Processors Selection of Supply Channels. Agribusiness, v. 12, n. 6, p. 509-523, 1996.

HOOKER, N.H.; CASWELL, J.A. Trends in Food Quality Regulation: Implications for Processed Food Trade and Foreign Direct Investment. Agribusiness, v. 12, n. 5, p. 411-419, 1996.

JANK, M.S. Programa de qualidade e o leite informal. Balde Branco, ano 34, n. 406, p. 24, agosto. 1998. 
KOTLER, P. Administração de marketing: Análise, planejamento, implementação e controle. $3^{\text {a }}$ edição. São Paulo: Ed. Atlas, 1994. 840p.

LEITE B. São Paulo SP, 1995 - 1999

MATTAR, F.N. Pesquisa de Marketing 1: Metodologia e planejamento. $4^{\text {a }}$ edição, São Paulo: Ed. Atlas, 1997. 336 p.

MATTAR, F.N. Pesquisa de Marketing 2: Execução e análise. $2^{\mathrm{a}}$ edição, São Paulo: Ed. Atlas, 1998. 224 p.

MEGIDO, J.L.T; XAVIER, C. Marketing \& Agribusiness. $3^{\text {a }}$ edição, São Paulo: Ed. Atlas, $1998.330 \mathrm{p}$.

MELCHER, R; BARRET, A. Grains that taste like meat?. Business Week, p.73, May $25,1998$.

MENKHAUS, D.J; COLIN, D.P.M.; WHIPPLE, G.D.; FIELD, R.A. The Effects of Perceived Product Attributes on the Perception of Beef. Agribusiness, v. 9, n. 1, p. $57-63,1993$.

MIRASOL, F. Ban on Animal Feed Antibiotics opens door to new alternatives. Chemical Market Report, vol. 257, n. 11, p.14, March , 2000.

NEVES, M.F. Um modelo para planejamento de canais de distribuição no setor de alimentos. São Paulo, 1999. 297 p. Tese (Doutorado) - Faculdade de Economia e Administração, Universidade de São Paulo.

PENGELLY, C. Joint venture \& low-risk deals gain in popularity. Animal Pharm: Review of 1997. p. 16-18, 1997. 
PEREIRA, H.M.S. Patentes na Indústria Farmacêutica: A adoção de patentes e o acesso a produtos farmacêuticos no Brasil. São Paulo, 1992. 270p. Tese (Mestrado) Faculdade de Economia e Administração, Universidade de São Paulo.

PIMENTA, M.C.; RICHERS, R. Segmentação: Opções Estratégicas para o Mercado Brasileiro. $1^{a}$ edição, São Paulo: Ed. Nobel, 1991. 300 p.

PINDYCK, R.S.; RUBINFELD, D. L. Microeconomia. $2^{\mathrm{a}}$ edição, São Paulo: Editora Makron Books, 1994. 968 p.

PORTER, M. E. Vantagem Competitiva. $7^{a}$ edição, Rio de Janeiro: Ed. Campus, 1992. 494p.

RICO, R.; RIVERAS, I. O triunfo do leite longa vida. São Paulo, Gazeta Mercantil, 30 de novembro de 1998. p. B22.

RIES, A.; TROUT, J. Posicionamento: A batalha pela sua mente. $6^{a}$ edição, São Paulo: Ed. Pioneira, 1996. 151 p.

ROZUM, J. A way to improve customer satisfaction. Quality Process. October, 1994. 5 p.

SAUER, P. Pet Companion Sales Drive Animal Health. Chemical Market Report. p. 89, October, 1999.

SEBRAE-MG/FEDERAÇÃO DA AGRICULTURA DO ESTADO DE MINAS GERAIS - Pesquisa direta. Belo Horizonte: SEBRAE, 1998. 
SPINOSA, H.S.; GÓRNIAK, S.; BERNARDI, M.M. Farmacologia Aplicada à Medicina Veterinária. $1^{2}$ edição, São Paulo: Ed. Guanabara Koogan, 1996. 545p.

STUART, K. Keeping them purring. Practical Accountant, v. 31, n. 3, p. 47-48, mar., 1998.

TAUER, L.W. The Value of Segmenting the Milk Market into BST-Produced and NonBST-Produced Milk. Agribusiness, v. 10, n. 1, p.3-12, 1994.

THAYER, A. Shering Plough ups its Animal Health Stake. Chemical \& Engineering News, v. 75, n. 21, p. 9, May 26, 1997.

VASCONCELLOS, E; PEREIRA, H.S. Patents in Pharmaceutical Sector: The case of developing countries. Apresentado no seminário: Internacional Perspectives on Business Ethics Conference, mar., 1992.

WAACK, R. S.; Distribuição de insumos veterinários no Brasil - Uma visão à partir da Economia dos Custos de Transação. Seminário mensal PENSA - FEA USP, agosto, $1999.30 \mathrm{p}$.

WAACK, R. S.; NEVES, M.F. Insumos Veterinários no Mercosul. Informações Econômicas, São Paulo, v.25, n. 8, p. 27-33, ago., 1995.

WAACK, R.S.; ZYLBERSZTAJN, D.; NEVES, M.F. Aspectos de tecnologia no setor produtor de insumos veterinários. Caderno de Pesquisa em Administração, ano 0, v. 0, n. 0, jul./dez. 1994.

WADE, M.A.; BARKLEY, A.P. The Economic Impacts of Ban on Subtherapeutic Antibiotics in Swine Production. Business Week, v. 9 , n. 2 , p. 93-106, 1992. 
WADSWORTH, K.H. What's hot what's not. Journal of Property Management, v. 63, n. 1, p. 24-26, Jan./Feb., 1998.

WALSH, K. Animal health. Chemical Week, v. 159, n. 27, p. 26, Jul. 16, 1997.

WALSH, K. Mallinckrodt sells veterinary unit to Shering Plough. Chemical Week, v. 159, n. 21, p. 9 , may $28,1997$.

WARDELL, D.G.; CANDIA, M.R. Statistical Process Monitoring of Customer Satisfaction Surveys Data. QMJ 96, n.4, p.36-50, 1996.

WESLEY, T.; HICKS, L. A Guide to the Brazilian Animal Health Market. London: PJB Publications Ltd., July 1992. 87p.

WOOD, T.J.; CURADO, I.B.; CAMPOS, H.M. Vencendo a crise: mudança organizacional na Rhodia Farma. Revista de Administração de Empresa. São Paulo, v. 34, n. 5, p. 62-79, set./out., 1994.

YEO, A. Industry hounds its political masters. Animal Pharm: Review of 1997. P. 5-6, 1997.

YOUNG, I. Rhone-Poulenc and Merck merge units. Chemical Week, v. 159, n. 1, p. 14, jan1-jan8, 1997.

ZYLBERSZTAJN, D; NETO SOUZA, A.; STAL, E.; WAACK, R.; GIORDANO, S.R.; LEPSCH, S.L. Biotecnologia no setor de insumos veterinários. São Paulo, PENSA - Programa dos Estudos do Sistema Agroindustrial: FIA - FEA - USP. jul., 1994. $155 \mathrm{p}$. 


\section{ENTREVISTAS}

1. Arnaldo Elias Sobrinho (Vallée) - Coordenador de pesquisa e mercado

2. Daniel J. Costa - Editor da Revista Nelore

3. Enrico Lippi Ortolani - Professor Doutor da Faculdade de Medicina Veterinária Universidade de São Paulo.

4. Fernando Heiderich (Schering Plough) - Diretor divisão veterinária

5. Ismael Lara (Bayer S.A.) - Chefe de produto

6. Jacó V. Tormes (Elanco) - Gerente da divisão de marketing e vendas

7. Luiz C. Lucas (Merial) - Diretor de Marketing

8. Márcio Cecantini (M. Cassab)

9. Marcos Jank - Professor da Escola Superior de Agricultura Luiz de Queiroz - USP

10. Mário Pires (Vallée) - Linha antiparasitários

11. Milson da Silva Pereira (SINDAN): Diretor executivo

12. Polípio Soares (Pearson) - Gerente da unidade de negócios

13. Roberto Losito - Professor da Escola Superior de Agricultura Luiz de Queiroz - USP

14. Roberto Waack (Boehringer Ingelheim) - Diretor do setor vetmédica da

15. Silvio Lazzarini - Consultoria SDF

16. Simone Kaiser (Virbac) - Gerente de marketing

Entrevistas por telefone

1. Cledson Walter (Pfizer)

2. José Popeye (Novartis)

3. Raul Moura (Fort Dodge.) 


\section{APÊNDICE}

Apêndice 1 - Tipo de especialização das vendas dos distribuidores e atacadistas

\begin{tabular}{|c|c|c|c|}
\hline & \begin{tabular}{|l|} 
Distribuidor/ \\
Atacadista
\end{tabular} & $\%$ vendas à revendas & $\%$ das vendas ao produtor \\
\hline \multirow[t]{6}{*}{ Sudeste } & Empresa 1 & $98,0 \%$ & $2,0 \%$ \\
\hline & Empresa 2 & $20,0 \%$ & $80,0 \%$ \\
\hline & Empresa 3 & $22,0 \%$ & $78,0 \%$ \\
\hline & Empresa 4 & $80,0 \%$ & $20,0 \%$ \\
\hline & Empresa 5 & $0,0 \%$ & $100,0 \%$ \\
\hline & Empresa 6 & $20 \%$ & $80 \%$ \\
\hline \multirow[t]{6}{*}{ Centro Oeste } & Empresa 1 & $30,0 \%$ & $70,0 \%$ \\
\hline & Empresa 4 & $80,0 \%$ & $20,0 \%$ \\
\hline & Empresa 5 & $46,0 \%$ & $54,0 \%$ \\
\hline & Empresa 6 & $70,0 \%$ & $30,0 \%$ \\
\hline & Empresa 7 & $0,0 \%$ & $100,0 \%$ \\
\hline & Empresa 8 & $60,0 \%$ & $40,0 \%$ \\
\hline Sul & Empresa 1 & $72,0 \%$ & $28,0 \%$ \\
\hline \multirow[t]{2}{*}{ Nordeste } & Empresa 1 & $95,0 \%$ & $5,0 \%$ \\
\hline & Empresa 2 & $70 \%$ & $30 \%$ \\
\hline
\end{tabular}

Fonte: Resultado junto às empresas 
Apêndice 2 - Tïpo de especialização das vendas de revenda de cooperativas

\begin{tabular}{|l|l|l|l|}
\hline & $\begin{array}{l}\text { Revenda de } \\
\text { Cooperativas }\end{array}$ & $\%$ vendas cooperados & $\%$ vendas não cooperados \\
\hline Sudeste & Cooperativa 1 & $96,5 \%$ & $3,5 \%$ \\
\hline & Cooperativa 2 & $75,0 \%$ & $25,0 \%$ \\
\hline & Cooperativa 3 & $80,0 \%$ & $20,0 \%$ \\
\hline & Cooperativa 4 & $90,0 \%$ & $10,0 \%$ \\
\hline & Cooperativa 5 & $95,0 \%$ & $5,0 \%$ \\
\hline & Cooperativa 6 & $98,0 \%$ & $2,0 \%$ \\
\hline & Cooperativa 7 & $90,0 \%$ & $10,0 \%$ \\
\hline & Cooperativa 8 & $80,0 \%$ & $10,0 \%$ \\
\hline & Cooperativa 9 & $80,0 \%$ & $20,0 \%$ \\
\hline & Cooperativa 1 & $90,0 \%$ & $10,0 \%$ \\
\hline & Cooperativa 2 & $70,0 \%$ & $30,0 \%$ \\
\hline & Cooperativa 3 & $95,0 \%$ & $5,0 \%$ \\
\hline & Cooperativa 1 & $75,0 \%$ & $25,0 \%$ \\
\hline & Cooperativa 2 & $80,0 \%$ & $20,0 \%$ \\
\hline & Cooperativa 3 & $80,0 \%$ & $20,0 \%$ \\
\hline & Cooperativa 4 & $95,0 \%$ & $5,0 \%$ \\
\hline & Cooperativa 5 & $60,0 \%$ & $40,0 \%$ \\
\hline & Cooperativa 6 & $90,0 \%$ & $10,0 \%$ \\
\hline & Cooperativa 7 & $80,0 \%$ & $20,0 \%$ \\
\hline & Cooperativa 8 & $80,0 \%$ & $20,0 \%$ \\
\hline
\end{tabular}

Fonte: Resultado junto às empresas 
Apêndice 3: Questionário para o canal de distribuição

Questionário

Nome do entrevistado:

Endereço:

Cep.: Cidade: Estado:

Tel.: Fax.:

Data:

Esclarecimentos:

Antibióticos: considerar os injetáveis, orais ou velas, com ou sem antiinflamatórios. Antiparasitários: considerar todos os tipos, gastrointestinais ou p/ combate externo.

Por favor, assinalar com um $\mathrm{X}$ a alternativa correspondente ao estabelecimento Este estabelecimento pode ser considerado, basicamente, como:

\begin{tabular}{|l|l|}
\hline (1) Distribuidor exclusivo & \\
\hline (2) Distribuidor não exclusivo & \\
\hline (3) Atacadista & \\
\hline (4) Revenda (pule para questão 4) & \\
\hline (5) Revenda de cooperativa (pule para questão 3) & \\
\hline
\end{tabular}

Se for um distribuidor ou atacadista, quantos porcentos das vendas é feita para:

\begin{tabular}{|l|r|}
\hline (1) Revendas & $\%$ \\
\hline (2) Produtor & $\%$ \\
\hline
\end{tabular}

Pule para questão 4

Se for uma revenda de cooperativa, quantos porcentos das vendas é feita para:

\begin{tabular}{|l|r|}
\hline (1) Cooperados & $\%$ \\
\hline (2) Não cooperados & $\%$ \\
\hline
\end{tabular}

$O$ faturamento anual bruto do estabelecimento pode ser enquadrado na categoria:

\begin{tabular}{|l|l|}
\hline (1) Menos que $R \$ 200.000 /$ ano & \\
\hline (2) Entre $R \$ 200.000$ e $R \$ 1.000 .000 /$ ano & \\
\hline (3) Entre $R \$ 1.000 .000$ e $R \$ 2.000 .000 /$ ano & \\
\hline (4) Entre $R \$ 2.000 .000$ e R $5.000 .000 / a n o$ & \\
\hline (5) Mais que R\$ 5.000.000/ano & \\
\hline
\end{tabular}

Coloque numa ordem de 1 (mais freqüente) a 4 (menos freqüente) as pessoas que vêm a loja comprar produtos veterinários:

\begin{tabular}{|l|l|}
\hline Produtor & \\
\hline Gerente/Capataz/Administrador & \\
\hline Veterinário & \\
\hline Peão & \\
\hline Outros, Qual? & \\
\hline
\end{tabular}


A faixa etária dos clientes, na maioria, situa-se:

\begin{tabular}{|l|l|}
\hline (1) Abaixo de 20 anos & \\
\hline (2) Entre 20 e 30 anos & \\
\hline (3) Entre 30 e 45 anos & \\
\hline (4) Acima de 45 anos & \\
\hline
\end{tabular}

A principal fonte de renda dos clientes é:

(1) Apenas pecuária

(2) Pecuária e atividades agrícolas

(3) Pecuária e outras atividades desenvolvidas na zona urbana

(4) Atividades não-agrícolas

Na maioria das vezes, o veterinário é chamado às propriedades dos seus clientes:

\begin{tabular}{|l|l|}
\hline (1) Com freqüência para orientar o manejo & \\
\hline (2) Só em caso de emergência & \\
\hline (3) Não costumam chamar o veterinário & \\
\hline
\end{tabular}

\section{PECUÁRIA DE LEITE}

O produtor de leite, geralmente, compra produtos veterinários:

\begin{tabular}{|l|l|}
\hline (1) Para uso imediato & \\
\hline (2) Para repor/fazer o estoque da propriedade & \\
\hline
\end{tabular}

As próximas questões devem ser respondidas ordenando as PREFERÊNCIAS DOS CLIENTES de 1 (mais importante) a 10 (menos importante), conforme a questão. Por exemplo, se o preço for o principal fator de escolha, coloque 1. Se em segundo lugar vier, por exemplo, inovação tecnológica, coloque 2 e assim por diante até o $n^{\circ} 10$.

Coloque numa ordem de 1 (mais importante) a 10 (menos importante) os atributos que 0 cliente considera importante, quando compra antibióticos para as vacas leiteiras.

\begin{tabular}{|l|l|}
\hline Preço & \\
\hline Qualidade & \\
\hline Inovação tecnológica & \\
\hline Tempo que não pode utilizar o leite & \\
\hline Tempo de intervalo de aplicação & \\
\hline Serviço pós venda oferecido pela empresa & \\
\hline Marca & \\
\hline Facilidade de aplicação & \\
\hline Design da embalagem & \\
\hline
\end{tabular}




\begin{tabular}{|l|l|}
\hline Não ser abortivo & \\
\hline Outros, qual? & \\
\hline
\end{tabular}

Coloque numa ordem de 1 (mais importante) a 10 (menos importante) os atributos que cliente considera importante, quando compra antiparasitários para vacas leiteiras.

\section{Preço}

Qualidade

Inovação tecnológica

Tempo que não pode utilizar o leite

Tempo de intervalo de aplicação

Serviço pós venda oferecido pela empresa fabricante

Marca

Facilidade de aplicação

Design da embalagem

Não ser abortivo

Outros, Qual?

Coloque numa ordem de 1 (mais importante) a 9 (menos importante) as formas de divulgação e promoção mais eficazes para medicamentos.

\begin{tabular}{|l|l|}
\hline TV & \\
\hline Revista especializada & \\
\hline Revista não especializada & \\
\hline Jornais de grande circulação & \\
\hline Jornais regionais & \\
\hline Jornais de cooperativa & \\
\hline Rádio & \\
\hline Mala direta & \\
\hline Propagandas em ponto de venda & \\
\hline
\end{tabular}

Coloque numa ordem de 1 (mais importante) a 10 (menos importante) as formas de propaganda que surtem melhor efeito no cliente (produtor de leite).

Cartazes de parede

Cartaz para balcão

Folhetos

Treinamento para balconista

Promoção com prêmios para balconista

Expositores para produtos

Palestras técnicas para o cliente e veterinários

Distribuição de amostra grátis

Serviço técnico de atendimento ao cliente 
Participação em feira e exposições

Outros, quais?

\section{EQUINOS}

O proprietários de cavalos geralmente compra produtos veterinários em:

(1) Para uso imediato

(2) Para repor/fazer o estoque da propriedade

Coloque numa ordem de 1 (mais importante) a 8 (menos importante) os atributos, que o cliente considera quando compra antibióticos para eqüinos.

\begin{tabular}{|l|l|}
\hline Preço & \\
\hline Qualidade & \\
\hline Inovação tecnológica & \\
\hline Tempo de intervalo de aplicação & \\
\hline Serviço pós venda oferecido pela empresa fabricante & \\
\hline Marca & \\
\hline Facilidade de aplicação & \\
\hline Design da embalagem & \\
\hline Outros, qual? & \\
\hline
\end{tabular}

Coloque numa ordem de 1 (mais importante) a 8 (menos importante) os atributos que o cliente considera quando compra antiparasitários para eqüinos.

\begin{tabular}{|l|l|}
\hline Preço & \\
\hline Qualidade & \\
\hline Inovação tecnológica & \\
\hline Tempo de intervalo de aplicação & \\
\hline Serviço pós venda oferecido pela empresa fabricante & \\
\hline Marca & \\
\hline Facilidade de aplicação & \\
\hline Design da embalagem & \\
\hline Outros, qual? & \\
\hline
\end{tabular}

Coloque numa ordem de 1 (mais importante) a 9 (menos importante) as formas de divulgação e promoção mais eficazes para medicamentos de cavalos:

\begin{tabular}{|l|}
\hline TV \\
\hline Revista especializada \\
\hline Revista não especializada \\
\hline Jornais de grande circulação \\
\hline Jornais regionais \\
\hline Jornais de cooperativa \\
\hline Rádio \\
\hline Mala direta \\
\hline Propaganda em ponto de venda \\
\hline
\end{tabular}


Coloque numa ordem de 1 (mais importante) a 8 (menos importante) as formas de propaganda que melhor surtem efeito no proprietário de eqüinos.

Cartaz de parede

Cartaz para balcão

Folhetos

Treinamento para balconista

Promoção com prêmios para balconista

Expositores para produtos

Participação de provas equiestres

Palestras para veterinários

Outros, quais? 
Apêndice 4 - Questionário para as empresas - ANÁLISE CONCORRENCIAL

EMPRESA:

LINHA DO PRODUTO:

Assinale as formas de distribuição utilizada pela empresa, o número de representantes e as principais regiões:

\begin{tabular}{|l|l|l|l|l|l|l|l|l|l|l|l|}
\hline & Sim & Não & \multicolumn{3}{|c|}{ Número de representantes } & \multicolumn{5}{|c|}{ Principais regiões } \\
\hline & & & $1-5$ & $6-10$ & $11-20$ & $>20$ & CO & SE & SUL & NO & NE \\
\hline $\begin{array}{l}\text { Distribuidores } \\
\text { exclusivos }\end{array}$ & & & & & & & & & & & \\
\hline $\begin{array}{l}\text { Vendedor } \\
\text { autônomo }\end{array}$ & & & & & & & & & & & \\
\hline $\begin{array}{l}\text { Vendedor } \\
\text { próprio }\end{array}$ & & & & & & & & & & & \\
\hline Venda direta & & & & & & & & & & & \\
\hline Atacadista & & & & & & & & & & & \\
\hline Revenda & & & & & & & & & & & \\
\hline
\end{tabular}

As principais regiões brasileiras $\left(1^{\circ}, 2^{\circ}\right.$ e $3^{\circ}$ lugar) na representatividade de vendas para bovinos de leite, corte e eqüinos são:

\begin{tabular}{|l|l|l|l|l|l|}
\hline & CO & SE & SUL & NO & NE \\
\hline Bovinos de leite & & & & & \\
\hline Bovinos de corte & & & & & \\
\hline Eqüinos & & & & & \\
\hline
\end{tabular}

A empresa trabalha com venda direta ao consumidor?

\begin{tabular}{|l|l|l|l|l|l|}
\hline & Sim & Não & \multicolumn{2}{|l|}{$\begin{array}{l}\text { Caso sim, há } \\
\text { serviços à } \\
\text { venda } \\
\text { Sim Não }\end{array}$} & Quais \\
\hline Bovinos de leite & & & & & \\
\hline Bovinos de corte & & & & & \\
\hline Eqüinos & & & & & \\
\hline
\end{tabular}

A política de vendas da empresa é voltada:

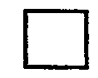

Volume de negócios

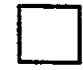

Linha do produto
Individualizada caso a caso 
5. A empresa adota qual política de desconto para os diversos canais de distribuição?

\begin{tabular}{|l|l|l|l|l|l|l|}
\hline & Desconto & \multicolumn{3}{|l|}{ Intervalo de desconto fornecido } \\
\hline & Sim & Não & $\begin{array}{l}\text { Menos que } \\
5 \%\end{array}$ & $5-10 \%$ & $11-20 \%$ & $\begin{array}{l}\text { Mais de } \\
20 \%\end{array}$ \\
\hline Venda Direta & & & & & & \\
\hline Atacadista & & & & & & \\
\hline $\begin{array}{l}\text { Distribuidor } \\
\text { exclusivo }\end{array}$ & & & & & & \\
\hline Revenda & & & & & & \\
\hline
\end{tabular}

Caso a empresa trabalhe com vendedores autônomos, a faixa de comissão concedida é:
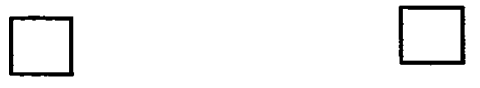
$1-5 \%$
$6-10 \%$
mais de $11 \%$

1. Assinale a porcentagem de vendas que cada canal de distribuição aproximadamente atinge para esta linha de produto:

\begin{tabular}{|l|l|l|l|l|}
\hline & $1-5 \%$ & $6-20 \%$ & $21-50 \%$ & Mais que 50\% \\
\hline Distribuidor exclusivo & & & & \\
\hline Autônomos & & & & \\
\hline Venda direta & & & & \\
\hline Atacadista & & & & \\
\hline Revenda & & & & \\
\hline
\end{tabular}

8. Assinale a participação estimada por canal nas vendas de produtos para BOVINOCULTURA DE CORTE:

\begin{tabular}{|l|l|l|l|l|}
\hline & $1-5 \%$ & $6-20 \%$ & $21-50 \%$ & Mais que 50\% \\
\hline Distribuidor exclusivo & & & & \\
\hline Autônomos & & & & \\
\hline Venda direta & & & & \\
\hline Atacadista & & & & \\
\hline Revenda & & & & \\
\hline
\end{tabular}


9. Assinale a participação estimada por canal nas vendas de produtos para bovinocultura de leite:

\begin{tabular}{|l|l|l|l|l|}
\hline & $1-5 \%$ & $6-20 \%$ & $21-50 \%$ & Mais que 50\% \\
\hline Distribuidor exclusivo & & & & \\
\hline Autônomos & & & & \\
\hline Venda direta & & & & \\
\hline Atacadista & & & & \\
\hline Revenda & & & & \\
\hline
\end{tabular}

10. Assinale a participação estimada por canal nas vendas de produtos para eqüinocultura:

\begin{tabular}{|l|l|l|l|l|}
\hline & $1-5 \%$ & $6-20 \%$ & $21-50 \%$ & Mais que 50\% \\
\hline Distribuidor exclusivo & & & & \\
\hline Autônomos & & & & \\
\hline Venda direta & & & & \\
\hline Atacadista & & & & \\
\hline Revenda & & & & \\
\hline
\end{tabular}

Em relação ao seu consumidor, a empresa pode afirmar que:

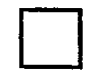

Conhece todas Conhece suas necessidades

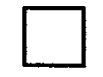
razoavelmente bem suas necessidades

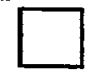

Tem noção do que o consumidor deseja e desejo do cliente necessita

Quantos \% do faturamento bruto da empresa é investido em Marketing?

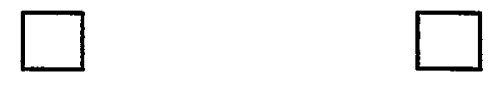

$1-3 \%$

mais de $6 \%$

Classifique em ordem de importância de 1 a 3 os principais influenciadores da demanda de produtos veterinários para bovinos de corte, leite e eqüinos.

\begin{tabular}{|l|l|l|l|l|l|l|}
\hline & Veterinários & $\begin{array}{l}\text { Empregad } \\
\text { os/peão }\end{array}$ & $\begin{array}{l}\text { Formadores } \\
\text { de opinião }\end{array}$ & Balconista & Vizinho & $\begin{array}{l}\text { Proprietári } \\
\text { os }\end{array}$ \\
\hline $\begin{array}{l}\text { Bovinos } \\
\text { de leite }\end{array}$ & & & & & & \\
\hline $\begin{array}{l}\text { Bovinos } \\
\text { de corte }\end{array}$ & & & & & & \\
\hline Eqüinos & & & & & & \\
\hline
\end{tabular}


Assinale as principais formas de comunicação utilizadas pela empresas no ano de 1998, para as diferentes regiões

\begin{tabular}{|l|l|l|l|l|l|}
\hline & SUL & SUDESTE & C-OESTE & NORTE & NORDESTE \\
\hline TV & & & & & \\
\hline Revista especializada & & & & & \\
\hline Revista não especializada & & & & & \\
\hline Jornais de grande circulação & & & & & \\
\hline Jornais regionais & & & & & \\
\hline Jornais de cooperativas & & & & & \\
\hline Rádio & & & & & \\
\hline Mala direta & & & & & \\
\hline $\begin{array}{l}\text { Merchandising em ponto de } \\
\text { venda }\end{array}$ & & & & & \\
\hline Outros: (exemplificar) & & & & & \\
\hline
\end{tabular}

Utiliza merchandising em ponto de vendas?

$\operatorname{Sim}$

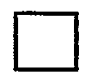

Não

Caso afirmativo, assinale em ordem de importância de 1 a 3 as formas utilizadas em 1998<smiles>C1CCC1</smiles>

Banner<smiles>C1CCC1</smiles>

Treinamento para balconista<smiles>C1CCC1</smiles>

Expositores para produtos

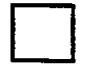

Cartaz para balcão

Promoção com prêmios para balconistas<smiles>C1CCC1</smiles>

Outros 
Classifique de 1 a 9 as variáveis que a empresa acha que o produtor considera mais importante quando adquire um produto veterinário (leite, corte e eqüinos).

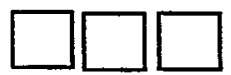

Qualidade

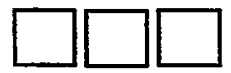

Serviço pós venda

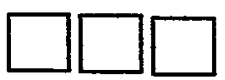

Período de carência

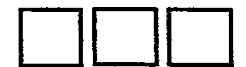

Inovação tecnológica

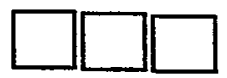

Facilidade de aplicação

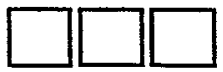

Tempo de latência

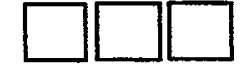

Preço

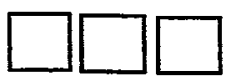

Design da embalagem

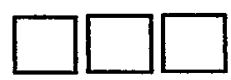

Outros, quais.... 